MARCOS MARAN

MANUTENÇÃO BASEADA EM CONDIÇÃO APLICADA A UM SISTEMA DE AR CONDICIONADO COMO REQUISITO PARA SUSTENTABILIDADE DE EDIFÍCIO DE ESCRITÓRIOS 
MARCOS MARAN

\section{MANUTENÇÃO BASEADA EM CONDIÇÃO APLICADA A UM SISTEMA DE AR CONDICIONADO COMO REQUISITO PARA SUSTENTABILIDADE DE EDIFÍCIO DE ESCRITÓRIOS}

Dissertação apresentada à Escola

Politécnica da Universidade de São Paulo para obtenção do título de Mestre em

Engenharia 
MARCOS MARAN

\title{
MANUTENÇÃO BASEADA EM CONDIÇÃO APLICADA A UM SISTEMA DE AR CONDICIONADO COMO REQUISITO PARA SUSTENTABILIDADE DE EDIFÍCIO DE ESCRITÓRIOS
}

\author{
Dissertação apresentada à Escola \\ Politécnica da Universidade de São Paulo \\ para obtenção do título de Mestre em \\ Engenharia \\ Área de Concentração: \\ Engenharia de Construção Civil e Urbana \\ Orientador: Prof. Dr. \\ Racine Tadeu Araújo Prado
}


Este exemplar foi revisado e alterado em relação à versão original, sob responsabilidade única do autor e com a anuência de seu orientador.

São Paulo, 24 de outubro de 2011.

Assinatura do autor

Assinatura do orientador

FICHA CATALOGRÁFICA

Maran, Marcos

Manutenção baseada em condição aplicada a um sistema de ar condicionado como requisito para sustentabilidade de edifício de escritórios / M.Maran. -- ed.rev. -- São Paulo, 2011. $121 \mathrm{p}$.

Dissertação (Mestrado) - Escola Politécnica da Universidade de São Paulo. Departamento de Engenharia de Construção Civil.

1. Manutenção preventiva 2. Edifícios (Durabilidade; Manu tenção) I. Universidade de São Paulo. Escola Politécnica. Departamento de Engenharia de Construção Civil II. t. 


\section{DEDICATÓRIA}

À Eliana,

Pelas palavras de motivação.

Aos meus pais,

Que sempre me apoiaram em tudo na vida.

A Deus, Que rege minha inspiração. 


\section{AGRADECIMENTOS}

Ao meu orientador, Prof. Dr. Racine T. A. Prado, que desde o início foi um incansável incentivador de meu trabalho. Somente com sua grande ajuda e disponibilidade foi possível concluir a dissertação.

Ao Marco Biasi e ao Alvino de Oliveira, que me apoiaram nesse projeto de vida desde o primeiro instante, sempre de maneira amiga e entusiasmada.

Ao Sidnei Bertazzoli, que sempre foi um grande incentivador.

Ao Aparecido Morilha, Luciano Luizetto e Eduardo Lunardini, que souberam conduzir o dia-a-dia do trabalho, me poupando o máximo possível de dores de cabeça.

À Bianca Dias, sem a qual nunca conseguiria organizar este trabalho. Sua dedicação e habilidade em desenhar figuras em CAD, formatar textos de acordo com as diretrizes, formatar infinitos textos e tabelas é digna de nota.

À Thaís Pires, com sua disponibilidade em ajudar em tudo. 


\section{RESUMO}

O impacto do Homem sobre a Terra, desde a extração intensiva dos recursos da natureza, extinção das espécies, emissões para o ar e água, consumo de energia e água até as mudanças climáticas do planeta, exigem medidas de contenção e preservação do meio ambiente. O futuro da humanidade é questionado e algo deve ser feito. Nesse contexto surge o conceito de desenvolvimento sustentável. Responsável pelo consumo de 40 a $50 \%$ da matéria-prima mundial, $12 \%$ da água e $40 \%$ das emissões de gases de efeito estufa, a indústria da construção possui importante papel na mitigação dos efeitos nocivos para o meio ambiente $e$ capacidade de atingir altos índices de sustentabilidade. Dentro do ciclo de vida de uma edificação, a fase de Operação/Uso provoca grandes consequências ao meio ambiente e oferece grandes oportunidades de redução dos efeitos adversos. Nessa fase as atividades de manutenção predial acabam por ter seu valor reconhecido. As diversas estratégias de manutenção, em especial a manutenção preventiva baseada em condição, colaboram efetivamente para a durabilidade, desempenho e função da edificação e seus sistemas prediais. Procedimentos de manutenção estão associados à baixa qualidade do ar. A manutenção de sistemas de ar condicionado tem especial destaque devido às consequências para a saúde, bem-estar e produtividade dos ocupantes do edifício.

Palavras-chave: Manutenção de edifícios. Manutenção corretiva e preventiva. Manutenção baseada em condição. Durabilidade. Ar condicionado. 


\begin{abstract}
Due to extensive extraction of nature's resources, extinction of species, emission of gases into the atmosphere, water and power consumption, to climatic changes of the planet, mankind's impact on earth requires containment and preservation of the environment. The future of humanity is being questioned and something must be done. Responsible for the consumption of 40 to $50 \%$ of raw materials worldwide, $12 \%$ of water and $40 \%$ of emissions of gases into the atmosphere causing the greenhouse effect, the construction industry has an important role in alleviating the adverse impacts on the environment and the ability to achieve high sustainable levels. Within the lifecycle of a building, the phase of operation/use causes significant environmental consequences but also offers opportunities to alleviate adverse effects. In this phase, the value of building maintenance activities has been recognized. The various strategies for maintenance, principally preventive conditionbased maintenance should collaborate effectively towards the durability, performance, function and systems of a building. Air-conditioning maintenance procedures are associated with poor air quality. The maintenance of air-conditioning systems has a special significance due to the effects on health, well-being and productivity of the occupants of the building.
\end{abstract}

Keywords: Building maintenance. Corrective and preventive maintenance. Conditionbased maintenance. Durability. Air conditioning. 


\section{LISTA DE ILUSTRAÇÕES}

Figura 1.1 - Dimensões do desenvolvimento sustentável

Figura 1.2 - Impacto ambiental de um edifício de escritórios para cada fase de um ciclo de vida (50 anos)

Figura 1.3 - Energia durante 50 anos de um edifício típico, com estacionamento subterrâneo, média entre estruturas em madeira, aço e concreto, em Vancouver e Toronto 26

Figura 1.4 - A influência da manutenção na vida útil 28

Figura 3.1 - Curva P-F 48

Figura 3.2 - Fluxograma de decisão para classificação de ativos para manutenção 50

Figura 3.3 - Árvore lógica de análise para escolha de estratégias de Manutenção 56

Figura 3.4 - Classificação de estratégias de manutenção 59

Figura 3.5 - Estratégias de manutenção - Estrutura 60

Figura 4.1 - Sistema de ar condicionado de expansão indireta e condensação a água - Circuito primário e secundário de distribuição de água gelada. 63

Figura 4.2 - Comparação das amplitudes das grandezas dinâmicas com a frequência 67

Figura 4.3 - Curva de tendência do valor global de vibração de rolamentos 68

Figura 4.4 (a) - Espectro de vibração que indica defeito na pista interna de rolamento $(192,5 \mathrm{~Hz})$ 69

Figura 4.4 (b) - Defeito (trinca) encontrado em pista de rolamento 69

Figura 4.5 - Gráfico de tendência de amplitude global do compressor centrífugo .. 70 Figura 4.6 (a) - Espectro de frequências de compressor centrífugo com desbalanceamento 70

Figura 4.6 (b) - Espectro de frequências do compressor centrífugo após balanceamento 71

Figura 4.7 (a) - Medição de espessura num trocador de calor através da técnica de ultrasom 74

Figura 4.7 (b) - Resultados obtidos da inspeção por ultrasom 74 
Figura 4.8 (a) - Imagem termográfica de motor com defeito em rolamento do lado acoplado

Figura 4.8 (b) - Disjuntor com sobreaquecimento nas fases S e T ..................... 79

Figura 4.9 - Fotos de um par de contatos elétricos ............................................. 80

Figura 4.10 (a), (b) e (c) - Situação de contatos elétricos de disjuntores .............. 82

Figura 4.11 - Correntes DC que circulam numa boa isolação ............................. 84

Figura 4.12 - Gráfico de acompanhamento da resistência de isolamento a 1 minuto de um motor elétrico

Figura 4.13 - Gráfico de tendência da resistência de isolamento durante um teste para obtenção dos índices de absorção e de polarização

Figura 4.14 (a) - Curvas de resistência de isolação para diferentes tensões de teste 88

Figura 4.14 (b) - Curvas de tendência para resistência de isolação sob diferentes tensões de teste 88

Figura 4.15 - Fator de potência da isolação - Relação entre as diversas correntes medidas 89

Figura 4.16 - Motor em boas condições de funcionamento ................................... 92

Figura 4.17 - Motor com rotor danificado ......................................................... 93

Figura 4.18 - Gases dissolvidos em relação à temperatura do óleo isolante ..........100

Figura 4.19 - Trinca entre dois furos detectada com partículas magnéticas ...........103

Figura 4.20 - Indicações de trincas sobre a solda com partículas magnéticas ....... 103

Figura 4.21 (a) - Ponta de prova típica de um teste Eddy Current no interior de 104 tubo (corte)

Figura 4.21 (b) - Inspeção dos tubos de um trocador de calor por Eddy Current ...104 


\section{LISTA DE TABELAS}

Tabela 1.1 - Estimativa de ganhos potenciais de produtividade devido melhorias nas condições de conforto do ambiente interior - em 1996 33

Tabela 3.1 - Aspectos positivos e negativos da Manutenção Corretiva RTF 43

Tabela 3.2 - Aspectos positivos e negativos da Manutenção Corretiva Não Planejada 44

Tabela 3.3 - Aspectos positivos e negativos da Manutenção Preventiva Periódica 47

Tabela 3.4 - Critério para classificação ABC de ativos para manutenção 51

Tabela 3.5 - Aspectos positivos e negativos da Manutenção Preventiva Baseada em Condição

Tabela 3.6 - Aspectos positivos e negativos principais da Manutenção Centrada em Confiabilidade. 58

Tabela 4.1 - Severidade e recomendações para análise de corrente 94

Tabela 4.2 - Gases detectados e possíveis causas de sua emissão 99

Tabela 4.3 - Equipamentos e técnicas preditivas aplicáveis 106 


\section{LISTA DE ABREVIATURAS E SIGLAS}

ABNT Associação Brasilieira de Normas Técnicas

ANVISA Agência Nacional de Vigilância Sanitária

ASTM American Society for Testing and Materials

BAC Bomba de água de condensação

BAG Bomba de água gelada

CAG Central de Água de Gelada

CBM Condition-Based Maintenance (Manutenção baseada em condição)

CFC Clorofluorcarbono

CIB International Council for Research and Innovation in Building and Construction

CPM Ciclos por minuto

CSA Canadian Standards Association

DC Direct current (corrente continua)

DGA Dissolved Gas Analysis (Análise de gases dissolvidos)

END Ensaios não destrutivos

ESA Electrical Signature Analysis (Análise de assinatura elétrica)

EUA Estados Unidos da América

FC Fan coil

FIESP Federação das Indústrias do Estado de São Paulo

FMEA Failure Mode and Effect Analisys (Análise do modo e efeitos de falhas)

FTA Failure Tree Analysis (Análise de árvore de falhas)

FT-IR Fourier Transform - Infrared Espectroscopy

GEE Gases de Efeito Estufa

GHG GreenHouse Gases

HFC Hidrofluorcarbono

IA Índice de absorção

ICP Espectroscopy Inductively Coupled Plasma Espectroscopy

IEC International Electrotecnical Commission

IP Índice de polarização

IPCC Intergovernmental Panel on Climate Change

IUCN International Union for the Conservation of Nature

LORUS Long Range Ultrasonics System 
LTA Logic Tree Analysis (Árvore Lógica de Decisão)

MC Manutenção corretiva

MCA Motor Circuit Analysis

MCC Manutenção centrada em confiabilidade

MCSA Motor Current Signature Analysis (Análise de assinatura de corrente de Motores)

MP Manutenção preventiva

MP-BC Manutenção preventiva baseada em condição

MPd Manutenção preditiva

MP-P Manutenção preventiva periódica

Mtoe Milhões de toneladas de óleo equivalente

NN Número ou Índice de Neutralização

NPR Número de prioridade de risco

PdM Predictive Maintenance

$\mathrm{PECl} \quad$ Portland Energy Conservation, Inc.

PFC Perfluorocarbonos

PIB Produto Interno Bruto

PT\&I Predictive Testing and Inspection

RCM Reliability-Centered Maintenance (Manutenção baseada em confiabilidade)

RTF Run-to-Failure

TAN Total Acid Number

TBN Total Base Number

TIF Tensão Interfacial

TTR Transformer Turn Ratio

UNEP United Nations Environment Programme

VAV Volume de ar variável

VRF Variable refrigerant flow (Volume variável de refrigerante)

WCED World Commission on Environment and Development 


\section{LISTA DE SÍMBOLOS}

${ }^{\circ} \mathrm{C} \quad$ Unidade de temperatura - graus celsius

$\Delta \quad$ Delta

$\begin{array}{lll}\theta & \mathrm{Fi}\end{array}$

A Corrente elétrica (Ampére)

$\mathrm{C}_{2} \mathrm{H}_{2} \quad$ Acetileno

$\mathrm{C}_{2} \mathrm{H}_{4} \quad$ Etileno

$\mathrm{C}_{2} \mathrm{H}_{6} \quad$ Etano

$\mathrm{CH}_{4} \quad$ Metano

CO Monóxido de carbono

$\mathrm{CO}_{2} \quad$ Dióxido de carbono

$d B \quad$ Decibel

$f_{l} \quad$ Frequência de linha $(60 \mathrm{~Hz})$

$f_{s} \quad$ Frequência de escorregamento

$\mathrm{H}_{2} \quad$ Hidrogênio

$\mathrm{H}_{2} \mathrm{O} \quad$ Água

Hz Hertz - Unidade de frequência elétrica - ciclos por segundo

$I_{A} \quad$ Corrente de absorção

$I_{C} \quad$ Corrente capacitiva

$I_{L} \quad$ Corrente condutiva

$I_{R} \quad$ Corrente resistiva

$I_{T} \quad$ Corrente total

$m^{2} \quad$ Unidade de área - Metro quadrado

$m^{3} \quad$ Unidade de área - Metro cúbico

$\mathrm{mm} / \mathrm{s} \quad$ Mílimetros por segundo

$\mathrm{N}_{2} \quad$ Nitrogênio

$\mathrm{N}_{2} \mathrm{O} \quad$ Óxido Nitroso

$\mathrm{O}_{2} \quad$ Oxigênio

$\mathrm{O}_{3} \quad$ Ozônio

RMA Valor eficaz ou médio quadrático

$\mathrm{SF}_{6} \quad$ Hexafluoreto de Enxofre

$V \quad$ Tensão (volts) 


\section{SUMÁRIO}

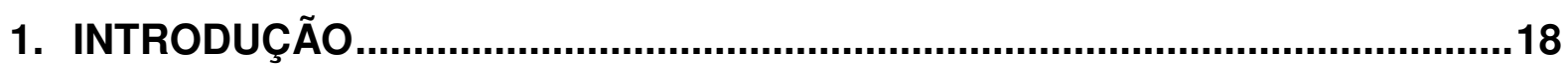

1.1. Impacto do Homem sobre a Terra e as Mudanças Climáticas .....................19

1.2. Desenvolvimento Sustentável ..........................................................21

1.3. Desenvolvimento Sustentável e a Indústria da Construção.........................23

1.3.1. Emissões para o ar, solo e água ................................................24

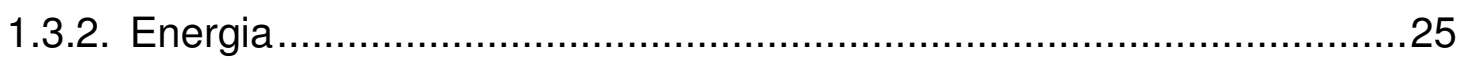

1.3.3. Manutenção predial e sustentabilidade ........................................27

1.3.4. Justificativa do presente trabalho ................................................30

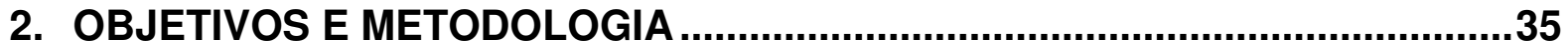

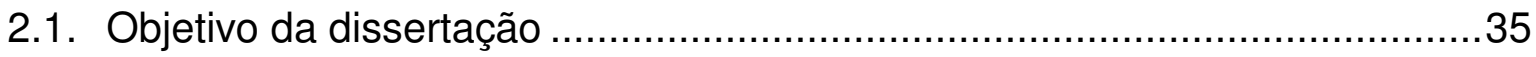

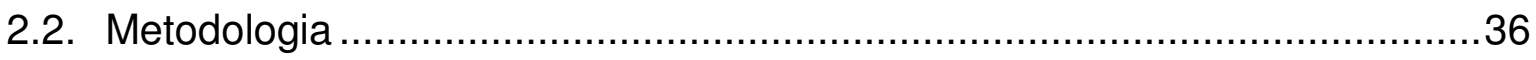

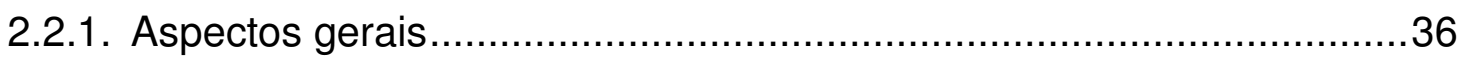

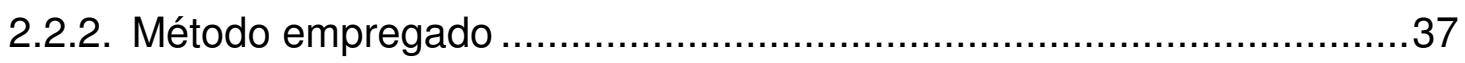

3. ESTRATÉGIAS DE MANUTENÇÃO APLICADAS A SISTEMAS PREDIAIS ...38

3.1. Manutenção - Termos e definições importantes ...................................38

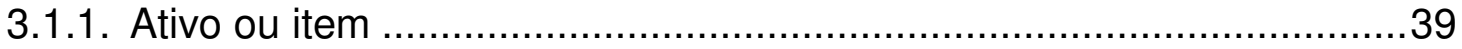

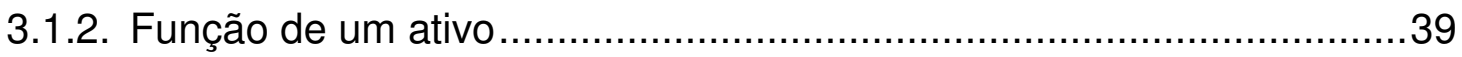

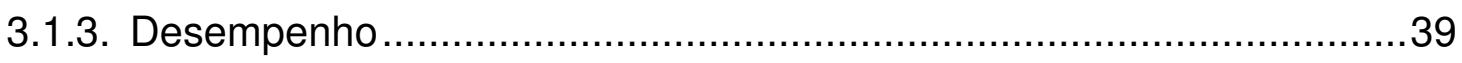

3.1.4. Defeito ou Falha Potencial .....................................................40

3.1.5. Falha ou Falha Funcional ....................................................40

3.1.6. Disponibilidade ............................................................. 40

3.1.7. Confiabilidade .................................................................. 41

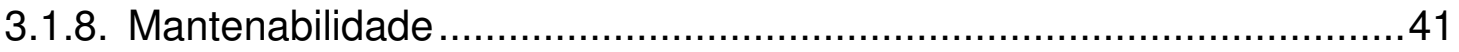

3.2. Estratégias de manutenção ......................................................... 41

3.2.1. Manutenção Corretiva ou Reativa ................................................42

3.2.1.1. Manutenção Corretiva Planejada ou RTF (Run-to-Failure ou Que Funciona até Falhar) .......................................... 42

3.2.1.2. Manutenção Corretiva Não Planejada (MC) ........................43

3.2.2. Manutenção Preventiva (MP) ................................................. 45

3.2.2.1. Manutenção Preventiva Periódica (MP-P)............................45

3.2.2.2. Manutenção Preventiva Baseada em Condição (MP-BC) .......48 
3.2.3. Manutenção Centrada em Confiabilidade (MCC) ...............................53

3.3. Estratégias e Estrutura de manutenção...................................................58

3.4. A manutenção preventiva baseada em condição e os requisitos de sustentabilidade para um edifício de escritórios

\section{APLICAÇÃO DE MANUTENÇÃO BASEADA EM CONDIÇÃO NUM SISTEMA DE AR CONDICIONADO PREDIAL}

4.1. O sistema de ar condicionado de expansão indireta e condensação a água

4.2. Manutenção Baseada em Condição - Técnicas de inspeção preditiva aplicadas a um sistema de ar condicionado de expansão indireta e condensação a água .64

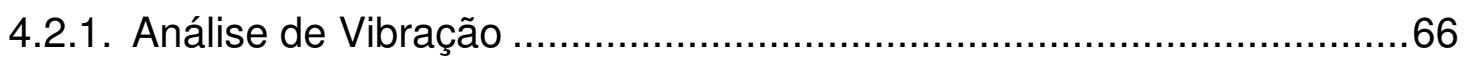

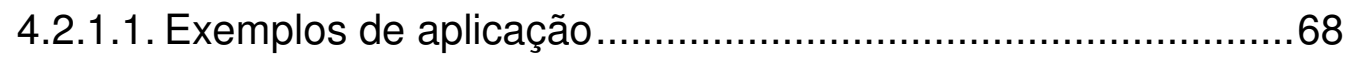

4.2.2. Análise por Ultrasom/Emissão Acústica..........................................71

4.2.2.1. Exemplo de aplicação.......................................................73

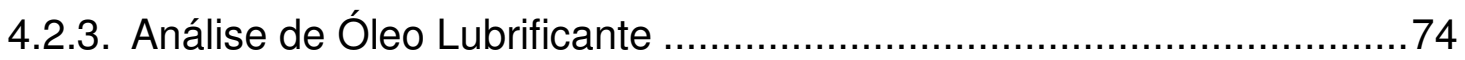

4.2.3.1. Principais testes em óleo lubrificante ...................................75

4.2.4. Análise Termográfica ou por Infravermelho ......................................76

4.2.4.1. Exemplo de aplicação..........................................................78

4.2.5. Resistência Ôhmica de Enrolamentos ................................................. 79

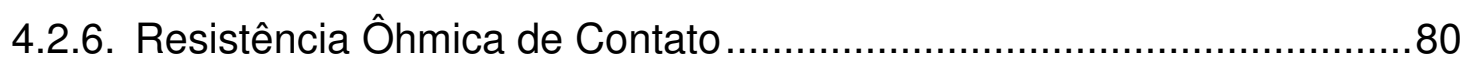

4.2.7. Resistência Ôhmica de Isolamento ................................................. 82

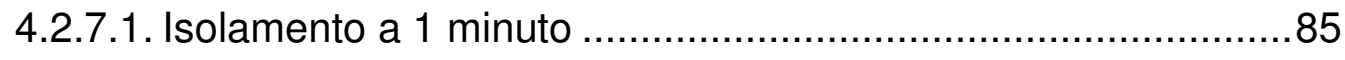

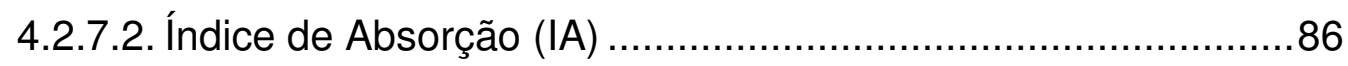

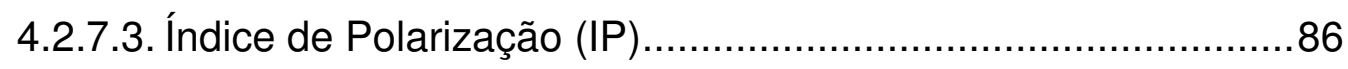

4.2.7.4. Resistência de isolamento sob múltiplas tensões de teste.......87

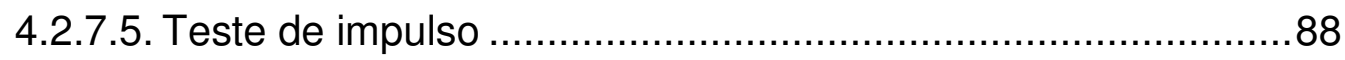

4.2.8. Fator de Potência da Isolação e Fator de Dissipação ...........................89

4.2.9. Análise de Circuito de Motor ou MCA (Motor Circuit Analysis) .............90

4.2.10. Análise de Assinatura de Corrente de Motores ou MCSA (Motor Current Signature Analysis)

4.2.11. Análise de Assinatura Elétrica ou ESA (Electrical Signature Analysis)

4.2.12. Análise de Óleo Isolante de Transformadores de Potência 
4.2.12.1. Análise físico-química de óleo isolante .96

4.2.12.2. Análise de gases dissolvidos de óleo isolante ou DGA (Dissolved Gas Analysis)....

4.2.12.3. Teor de Compostos Furânicos (2-furfural) 101

4.2.13. Relação de Transformação de Transformadores ou TTR (Transformer Turn Ratio) 101

4.2.14. Ensaios Não Destrutivos (END) 101

4.2.15. Equipamentos e técnicas preditivas aplicáveis - resumo 105

5. CONSIDERAÇÕES FINAIS 108 REFERÊNCIAS. 112 


\section{INTRODUÇÃO}

No século XVIII a sociedade que até então vivia praticamente da agricultura e dos bens produzidos por artesãos começa a mudar, passando a usufruir de mercadorias fabricadas em escala industrial. Surge uma grande e nova disponibilidade de bens, acompanhada de maior riqueza e recursos financeiros para investimentos em meios de produção. A renda aumenta e melhora sua distribuição nas várias camadas da população. Nesse contexto começa a florescer a indústria da construção civil. A fabricação de produtos exige uma nova classe de abrigos para equipamentos, pessoal envolvido na fabricação e estocagem de mercadorias. Caminhos são renovados ou implantados sob novo conceito e tornam-se as estradas necessárias para escoamento dos insumos e produtos, portos são construídos, melhorados e ampliados, estradas de ferro e usinas de força são construídas. A migração do campo para as cidades se intensifica devido às maiores oportunidades de trabalho e salário, exigindo a edificação e reforma de moradias, bem como uma nova infra-estrutura de serviços e espaços públicos.

Em pouco mais de 250 anos a humanidade alcançou um extraordinário padrão econômico, tendo como consequência notável progresso como um todo. Esse avanço se refletiu também em melhorias significativas na saúde e bem-estar da população, contribuindo para seu crescimento vertiginoso. De 1750 ao ano 2000 a quantidade de pessoas sobre a Terra passou de cerca de 1 bilhão para 6 bilhões, podendo chegar a cerca de 10 bilhões até o final deste século (SOUBBOTINA, 2004).

Parecendo um processo evolutivo auto-alimentado, todo esse desenvolvimento faz com que a retirada de recursos da natureza para produção de bens seja cada vez maior, de modo a sempre atender mais pessoas. Incessantemente, mais e mais insumos naturais são extraídos da terra, transformados, transportados, utilizados e, no fim da vida útil, descartados, devolvidos à natureza, onde se espera que sejam absorvidos pelo solo. Todas essas etapas acabam por contribuir para exaustão e degradação do meio ambiente, além de serem responsáveis por grande parte das mudanças climáticas no mundo. 


\subsection{Impacto do Homem sobre a Terra e as Mudanças Climáticas}

Com relação ao impacto das atividades humanas sobre o planeta e a capacidade deste em suprir ao consumo de recursos naturais, Rees e Wackernagel apud Cervi e Carvalho (2006), em 1994 propõem o método da "Pegada Ecológica" (em inglês, ecological footprint) para cálculo "da área de terreno produtivo necessária para sustentar o nosso estilo de vida". Por esse método, para cada atividade humana, população, produto, etc, é possível estabelecer uma área equivalente de solo e/ou de água, cuja soma é comparada com a biocapacidade do planeta, ou seja, com área terrestre e aquática biologicamente ativa da Terra. De acordo com os mesmos autores, em termos mundiais, em 2003 a "Pegada Ecológica" correspondia a 2,2 hectares per capita, enquanto a biocapacidade global era de 1,8 hectares, ou seja, um déficit de 0,4 hectares per capita.

Quanto às mudanças climáticas, são alterações dos padrões de temperatura, chuvas e ventos por longo período, décadas ou mais, devido a fatores naturais ou a fatores ligados às atividades do Homem. Tanto um fator como o outro estão diretamente ligados ao efeito estufa da atmosfera terrestre. Do total da energia do Sol que atinge a Terra, parte, cerca de $31 \%$ é refletida novamente para o espaço e, o restante, é absorvido pela atmosfera (+/- 19\%) e superfície terrestre (+/- 50\%). No processo de manutenção de seu equilíbrio energético, a Terra emite a energia absorvida (no solo e mares) de volta para o espaço, porém uma porção desta é retida pela atmosfera, incluindo nuvens, e reemitida de volta para a superfície, aquecendo-a novamente. Esse processo natural, que mantém a Terra aquecida, é chamado efeito estufa. Sem esse efeito, a temperatura da superfície da Terra seria muito menor, próxima do congelamento da água ou mais baixa, tornando impossível a vida no planeta como a conhecemos (US-EPA-SCIENCE, 2010; SOLOMON et al., 2007).

Presentes naturalmente na atmosfera, os chamados gases de efeito estufa (GEE ou GHG - GreenHouse Gases), uma vez que colaboram para esse fenômeno, mais importantes são, respectivamente, o vapor d'água e o dióxido de carbono $\left(\mathrm{CO}_{2}\right)$. Outros GEE naturais também presentes, mas em menor escala, são o metano $\left(\mathrm{CH}_{4}\right)$, óxido nitroso $\left(\mathrm{N}_{2} \mathrm{O}\right)$ e o ozônio $\left(\mathrm{O}_{3}\right)$. Também colaboram para esse efeito os gases sintéticos criados no século passado, tais como, os 
Clorofluorcarbonos (CFC), os Hidrofluorcarbonos (HFC), os Perfluorocarbonos (PFC) e os Hexafluoreto de Enxofre $\left(\mathrm{SF}_{6}\right)$, além de causarem outras anomalias em nossa atmosfera (US-EPA-GHG, 2010; SOLOMON et al., 2007).

Fatores naturais, tais como, alterações na intensidade solar, correntes marítimas e ar atmosférico, atividades vulcânicas ou pequenas mudanças na órbita da Terra em torno do Sol, podem mudar o efeito estufa e, assim, provocar mudanças climáticas. E isso aconteceu diversas vezes ao longo da historia. Porém, desde o início da Era Industrial, a cerca de 250 anos, as atividades do Homem incrementaram substancialmente a presença dos GEE na atmosfera do planeta. A queima de combustíveis fósseis, desmatamento, ocupação de áreas de terra para produção agrícola e urbanização, bem como o aumento da produção para atender a demanda de bens, entre outras causas, teve como consequência a alteração da composição química da atmosfera da Terra e a intensificação do efeito estufa. $O$ aumento dos GEE, somente o dióxido de carbono teve um crescimento $35 \%$ nesse período, leva ao acréscimo de vapor de água, que por sua vez amplia o aquecimento da Terra, que novamente provoca mais vapor, num ciclo interminável auto-sustentado. Esse vapor de água pode representar o dobro do efeito provocado somente pelo $\mathrm{CO}_{2}$. Essa situação leva à elevação contínua da temperatura do planeta e substanciais implicações para o clima (SOLOMON et al., 2007).

Conforme a agência US-EPA-SCIENCE, (2010), "os dados do século passado mostram um aumento de temperatura médio de $0,74{ }^{\circ} \mathrm{C}$. Nos últimos 30 anos, a taxa de aquecimento através do globo tem sido aproximadamente 3 vezes maior que a taxa dos 100 anos anteriores". Ainda de acordo com essa agência, se as emissões de GEE continuarem em ritmo igual ou superior às atuais, a temperatura média da Terra poderá sofrer um incremento de 2 a $4^{\circ} \mathrm{C}$ até o ano 2100.

Mesmo no caso de se conseguir reduzir e manter as emissões ao mesmo nível do ano 2000, a temperatura do planeta aumentará cerca de 0,6 ${ }^{\circ} \mathrm{C}$ (US-EPA SCIENCE, 2010). Embora parecendo valores não significativos, a elevação da temperatura média e sua manutenção durante longos períodos provoca alterações climáticas no planeta, que afetam a natureza e, consequentemente, o Homem e seu modus vivendi. Análises do IPCC - Intergovernmental Panel on Climate Change indicam que, apesar de não se ter ainda condições de avaliar de modo preciso, o aumento do aquecimento da Terra provocará muito mais consequências negativas 
que positivas, consequências essas tanto maiores, em custo e em dificuldades de adaptação, quanto mais rápido for o citado aquecimento (US-EPA-EFFECTS, 2010).

Dentre os principais impactos provocados pela elevação de temperatura terrestre e as mudanças climáticas decorrentes, pode-se citar (US-EPA-EFFECTS, 2010; HOUGHTON et al.,1997): diminuição das camadas de gelo e neve nas regiões polares; aumento do nível e acidificação da água; maior frequência e porte das tempestades nos oceanos e mares; inundações, salinização de aqüíferos e erosão em regiões costeiras; intensificação do ciclo de água/secas nas porções continentais da Terra; calor, secas, inundações e tempestades podem provocar queda na produção de alimentos, rendimento e adaptação das espécies; alteração de florestas e ecosistemas, mudança de habitats e padrões migratórios; nas cidades, agravamento de doenças respiratórias, mortes devido ondas de calor e baixa qualidade do ar, etc.

\subsection{Desenvolvimento Sustentável}

A partir da década de 1960, diante da constatação do efeito prejudicial ao Homem, medidas de contenção e preservação do meio ambiente se tornam tema de importância mundial. O grande crescimento econômico, a constatação da finitude dos recursos naturais e as crises sociais decorrentes colocam em dúvida o modelo tradicional de desenvolvimento humano (COHEN; BRUYN; FAROLE, 2009; STRANGE; BAYLEY, 2008).

Em 1972, em Estocolmo, durante a Conferência das Nações Unidas sobre Meio Ambiente (United Nations Conference on the Human Environment), os conflitos entre meio ambiente e desenvolvimento são finalmente reconhecidos.

Com a publicação da Estratégia Mundial para a Conservação (World Conservation Strategy) em 1980 pela IUCN (International Union for the Conservation of Nature), a conservação é defendida como um meio para utilização das espécies, ecossistemas e recursos naturais com intuito de auxiliar o desenvolvimento sustentável (KATES; PARRIS; LEISEROWITZ, 2005). De acordo com Hill e Bowen (1997, p. 224), nessa publicação se faz 
[...] uma alteração significativa em relação à conservação da natureza, da prática de preservação de reservas ambientais para uma perspectiva onde conservação e desenvolvimento são entendidos como conceitos integrados. A Estratégia define desenvolvimento como 'alteração da biosfera para satisfazer as necessidades humanas', e conservação como 'a gestão do uso da biosfera pelo ser humano que leva aos maiores resultados sustentáveis tanto para a presente quanto para as futuras gerações.

No relatório Brundtland, de 1987, Nosso Futuro Comum (Our Common Future), surge o conceito de desenvolvimento sustentável como é adotado até os dias atuais. Nesse documento "desenvolvimento sustentável é o desenvolvimento que atende às necessidades do presente sem comprometer a capacidade das futuras gerações de atender às suas próprias necessidades” (WCED, 1987). Tendo como premissa as necessidades e o bem-estar do Homem, este relatório mostra a urgência da humanidade repensar seu estilo de vida, visto a aceleração da degradação do meio ambiente, diminuição dos recursos naturais e suas consequências para a economia e o desenvolvimento social. Seja numa forma de sociedade industrializada ou rural de subsistência, a humanidade, para a sua segurança e existência, depende da natureza e seus ecossistemas. Finalmente, esse relatório consolida 0 conceito de desenvolvimento sustentável ou sustentabilidade: integridade do meio ambiente, prosperidade econômica e justiça social (STRANGE; BAYLEY, 2008; HOPWOOD; MELLOR; O’BRIEN, 2005; BANSAL, 2005).

De acordo com Ree e Meel apud Williams e Sutrisna (2010), as dimensões ou princípios do desenvolvimento sustentável, Meio Ambiente, Economia e Sociedade, podem ser mostradas por meio de três anéis como indicado na figura 1.1, onde a intersecção representa a obrigatoriedade da presença dessas três dimensões, respectiva integração e balanceamento para que se consiga o desenvolvimento sustentável. 


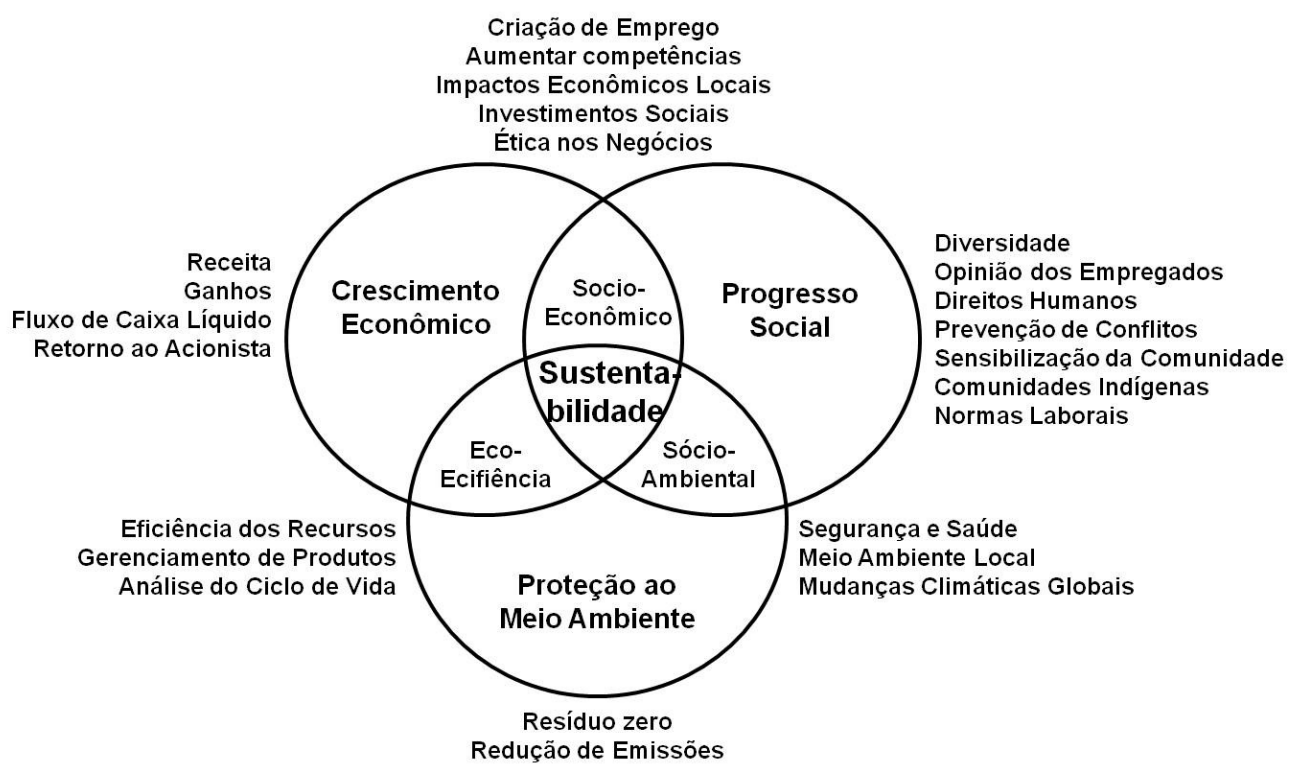

Figura 1.1 - Dimensões do desenvolvimento sustentável

Fonte: REE e MEEL apud WILLIAMS e SUTRISNA, 2010, adaptada

\subsection{Desenvolvimento Sustentável e a Indústria da Construção}

Suporte do progresso do Homem, a indústria da construção possui relevante importância em todas as dimensões do desenvolvimento sustentável. Sua cadeia produtiva é complexa e heterogênea, participando dela diversos setores industriais, tais como mineração, siderurgia, metalurgia, químico, vidros, cimento, plásticos, revestimentos, equipamentos elétricos e mecânicos, escritórios de projetos e serviços especializados de engenharia entre outros. Abrange empresas de diversos portes, muitas de capital intensivo, caracterizando-se pelo desenvolvimento de processos tecnológicos variados, desde os mais complexos até os mais simples (MELO; AMORIN, 2009).

Conforme o Programa Ambiental das Nações Unidas (United Nations Environment Programme - UNEP, 2007), aproximadamente 3 a 4,2 trilhões de dólares anuais são despendidos no mundo todo pelo setor da construção, o que o torna responsável, na média nacional dos países, por cerca de 5 a $10 \%$ dos empregos e de 5 a 15\% do produto interno bruto. No Brasil, conforme o relatório do 7ํㅗㄹ Seminário da Indústria Brasileira da Construção - ConstruBusiness 2008 (FIESP, 2008), esse setor "responde por $11,3 \%$ do PIB, por cerca de $40 \%$ do investimento produtivo e por quase $20 \%$ dos empregos formais do país. De expressiva 
participação no mercado de bens duráveis, o setor contribui positivamente para o desenvolvimento econômico e social, mas como no resto do mundo, também provoca significativo impacto negativo no meio ambiente. Abrangendo basicamente os sub-setores de edificações, construção pesada e materiais, a indústria da construção além de grande ocupante de solos, revela-se grande consumidora de recursos naturais, de energia e água, bem como grande geradora de emissões prejudiciais para o meio ambiente durante todo o seu ciclo de vida.

Como referência ao impacto que causam na natureza, "anualmente, em torno de 3 bilhões de toneladas de matérias-primas - $40-50 \%$ do fluxo total da economia mundial - são usados na manufatura de produtos e componentes para construção de edifícios no mundo todo". Cerca de 2.500 Mtoe (milhões de toneladas de óleo equivalente) de energia são consumidos nas edificações anualmente, o que representa de 30 a $40 \%$ do consumo mundial (UNEP, 2007). Langston et al. (2008) resumem: "...com relação aos recursos naturais, em termos globais, as edificações são responsáveis pela extração de $32 \%$ dos recursos naturais, consumo de $12 \%$ da água, $40 \%$ de rejeitos depositados em aterros e $40 \%$ das emissões de gases de efeito estufa". Todo esse impacto e suas consequências para a natureza e futuro do Homem colocam a indústria da construção como um importante setor da economia onde os conceitos de sustentabilidade devem e podem ser desenvolvidos.

\subsubsection{Emissões para o ar, solo e água}

Com o intuito de estudar as consequências que a construção, uso e operação e demolição de prédios provocam em termos de emissões para o meio ambiente, Junnila e Horvath (2003) escolheram um edifício de escritórios localizado no sul da Finlândia com área de $15.600 \mathrm{~m}^{2}$, volume de $61.700 \mathrm{~m}^{3}$ e 5 andares. O ciclo de vida considerado para a edificação foi de 50 anos e, excetuando-se a etapa de extração de materiais, todas as demais foram incluídas no estudo. As emissões para o meio ambiente foram analisadas para cada etapa do ciclo de vida. De acordo com a figura 1.2, na etapa de transformação de matérias primas em produtos para construção ocorre alto nível de emissões, mas é na fase de uso/operação do edifício que acontecem as maiores consequências para o meio ambiente. Isso ocorre devido ao 
longo período considerado (50 anos) juntamente com o consumo de energia, de materiais de manutenção e reformas nesse período. Destacam-se nessa etapa, os serviços de eletricidade para os equipamentos de aquecimento (o edifício estudado se localiza numa região fria do planeta), ventilação e ar condicionado, iluminação, etc. Esses sistemas estão fortemente relacionados ao conforto das pessoas no ambiente de trabalho. Os menores impactos se devem às etapas de construção e demolição. Pode-se observar que são grandes as emissões que acontecem na fase de uso e operação do edifício e que afetam as mudanças climáticas e poluem solo e água.

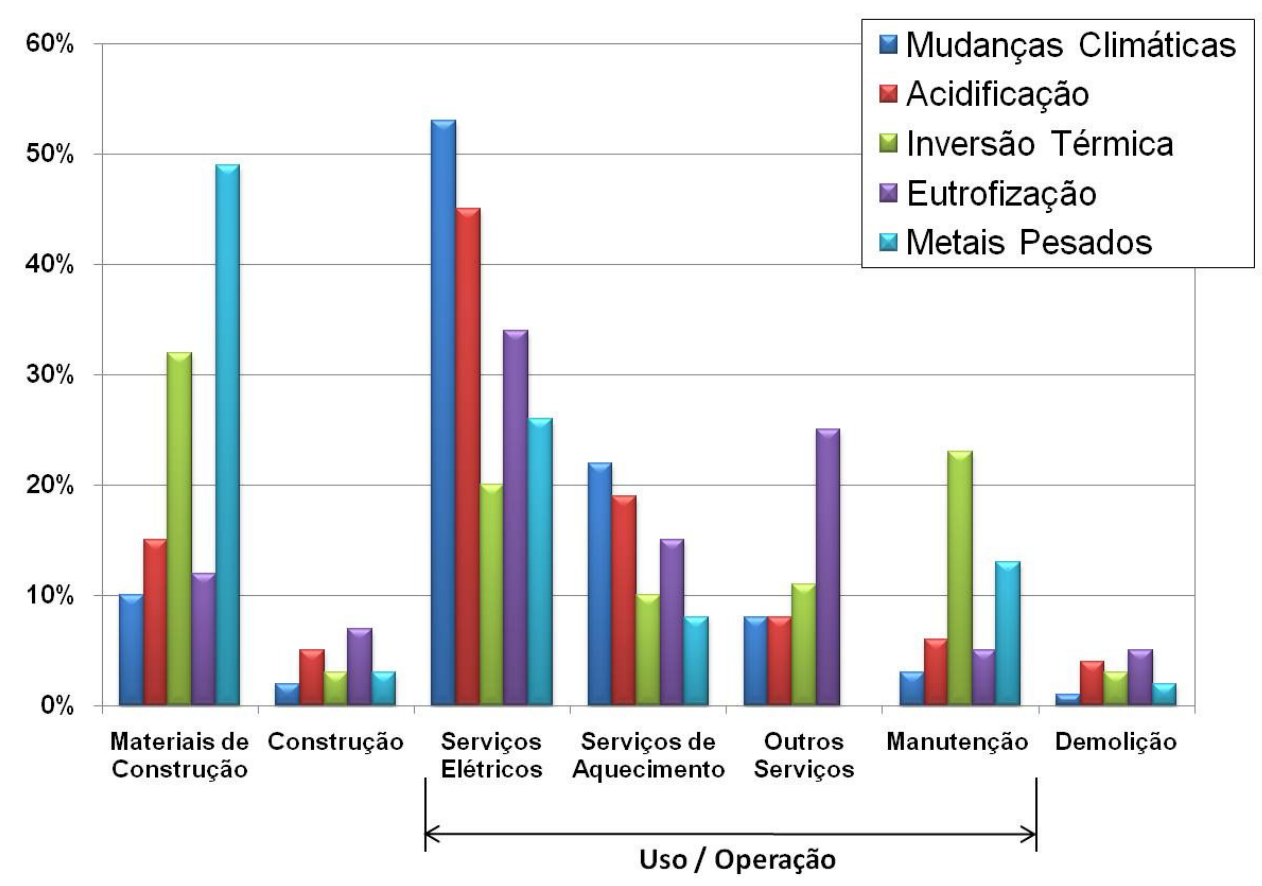

Figura 1.2 - Impacto ambiental de um edifício de escritórios para cada fase de um ciclo de vida (50 anos)

Fonte: JUNNILA e HORVATH, 2003, adaptada

\subsubsection{Energia}

Toda a energia consumida num edifício durante seu ciclo de vida consiste da energia embutida (ou incorporada ou inicial - initial, embodied or primary energy), da energia de operação (ou operacional - operational/operating/operation energy) da edificação e da energia recorrente (recurring energy) (SCHULTMANN; SUNKE, 2007). 
A energia embutida compreende a somatória de toda a energia utilizada na extração de matéria-prima do meio ambiente, seu refinamento, transporte, manufatura e transformação em produtos da construção (energia indireta). Inclui também toda a energia utilizada na aplicação desses produtos para construção do edifício (energia direta). Essa energia ocorre na fase de implantação, ou seja, nos 3 a 4 anos iniciais do ciclo de vida do prédio. A energia operacional consiste na energia utilizada no funcionamento/operação dos sistemas do prédio quando este está ocupado, como por exemplo, sistemas de ar condicionado, ventilação, aquecimento, iluminação, elevadores, bombeamento de água, sistemas de supervisão, entre outros e compreende a vida útil da edificação, normalmente considerada entre 50 a 100 anos. Quanto à energia recorrente, trata-se da energia usada nos serviços e materiais de manutenção, de reparos diversos, de reformas e adaptações do prédio também durante a vida de 50-100 anos (SCHULTMANN; SUNKE, 2007; COLE; KERNAN, 1996; FAY; TRELOAR; IVER-RANIGA, 2000).

Cole e Kernan (1996) num trabalho realizado no Canadá, estudaram a quantidade de cada uma dessas de energias para um edifício ao longo de 50 anos e para diferentes tipos de estrutura (madeira, aço e concreto). Com a média dos dados obtidos foi elaborado o gráfico da figura 1.3.

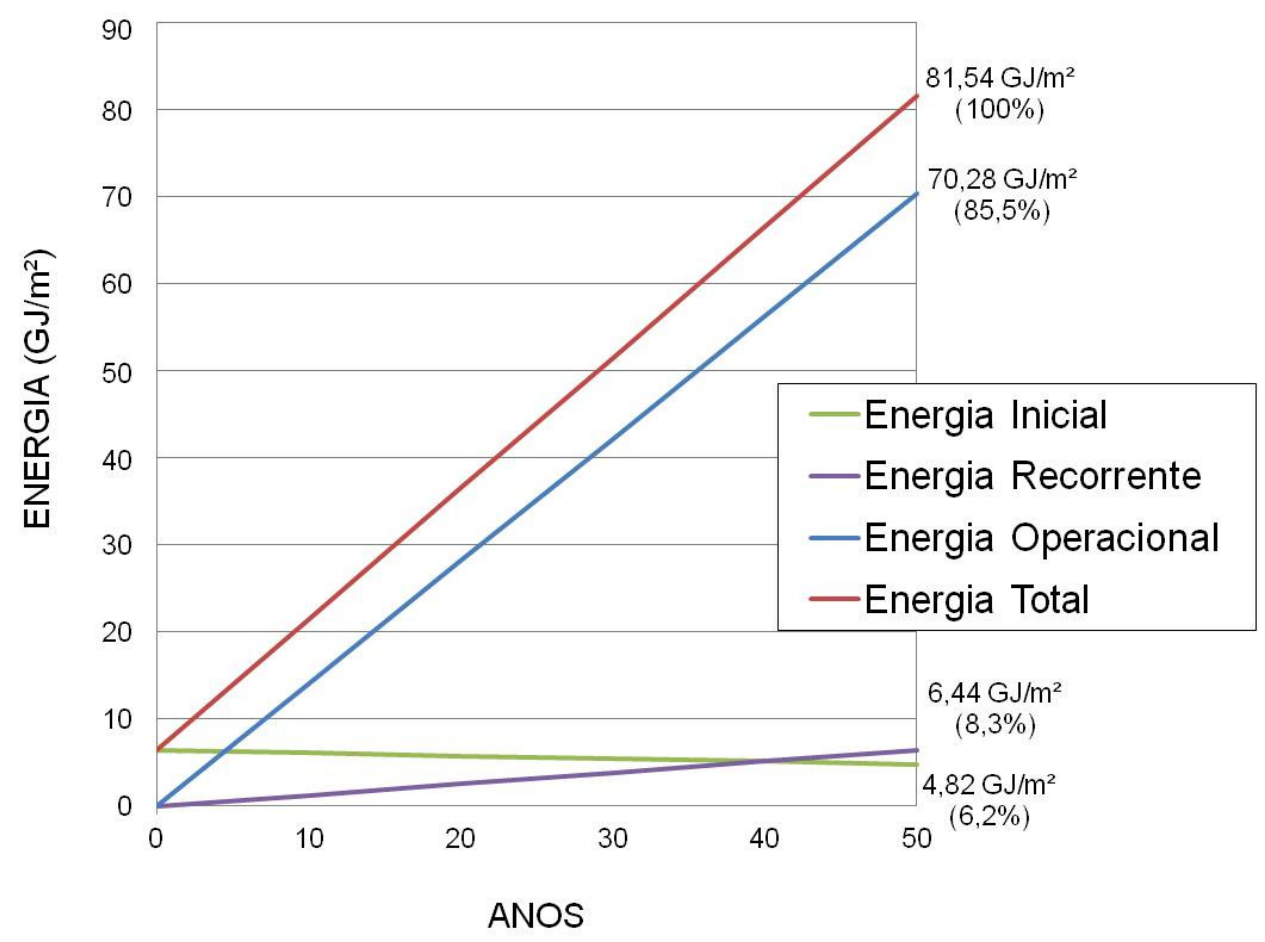

Figura 1.3 - Energia durante 50 anos de um edifício típico, com estacionamento subterrâneo, média entre estruturas em madeira, aço e concreto, em Vancouver e Toronto

Fonte: COLE e KERNAN apud UNEP, 2007, adaptada 
Como se nota a energia operacional se destaca perante as demais, salientando o impacto do funcionamento dos sistemas prediais durante toda a vida útil do edifício. A quase igualdade existente entre a energia embutida ou inicial e a recorrente, com esta ultrapassando aquela no final do período, mostra o importante peso da energia utilizada nas atividades de operação, manutenção e conservação frente às demais.

Crowther (1999, p. 2), citando vários autores, complementa que do total de energia embutida numa edificação, 5 a 13\% se referem a energia direta, empregada na construção propriamente dita. Do montante restante, 20 a 50\% estão incorporados na estrutura predial, sendo que o resto, 50 a 70\%, em seu envelope, arranjos internos, acabamentos e serviços. As atividades de demolição e de disposição final dos resíduos podem chegar a 5\% do montante total. Conforme esse autor, durante sua vida útil é razoável supor que o prédio passará por várias reformas, maiores e menores, e, segundo ele, “...estudos recentes (COLE; 1996; HOWARD, 1994; SUZUKI, 1998; TUCKER, 1993) tem mostrado que a energia embutida nos trabalhos de renovação/adaptação do edifício ao longo de sua vida pode vir a ser de 20 a $100 \%$ da energia embutida inicial”.

\subsubsection{Manutenção predial e sustentabilidade}

Visto de uma maneira simples, o ciclo de vida do edifício pode ser dividido em três etapas: a etapa de construção, que engloba as fases de extração, transformação de materiais e construção propriamente dita; a etapa de operação/uso do prédio, quando este está ocupado, e a última etapa, referente à sua demolição, após a perda de seus atributos de interesse comercial, cultural e social. Conforme os trabalhos de Cole e Kernan apud UNEP (2007) e Junnila e Horvath (2003), nas duas primeiras etapas se concentram os maiores impactos e consequências para o meio ambiente e Homem. Embora com os mesmos objetivos, isto é, criar valor para proprietários e satisfazer as necessidades usuários da edificação, por meio do estabelecimento de espaço de convivência e de negócios adequados, os processos adotados nessas etapas são diferentes. Enquanto numa a preocupação é com ações de projetar e erigir uma edificação inexistente, na outra o 
interesse é empreender atividades de operação e manutenção, incluindo adaptação e renovação, da edificação erigida.

Anteriormente sem expressão no contexto do ambiente construído, que se preocupava quase que somente com a atividade de construção, as ações de manutenção de uma edificação ganharam significativo valor e reconhecimento sob os princípios do desenvolvimento sustentável. A fase de operação e manutenção de edifícios possui custo e impacto ambiental maior que a fase de construção e tem preponderante influência nos resultados econômicos e sociais de um edifício. As três dimensões da sustentabilidade, proteção ao meio ambiente, crescimento econômico e progresso social, se encontram sob a égide da gestão de manutenção predial.

A British Standards Institution (1991), estabelece que a manutenção predial pode ser definida como "combinação de todas as técnicas e ações administrativas, incluindo ações de supervisão, destinados a manter ou restaurar um ativo, a um estado em possa desempenhar uma função requerida" (WOOD, 2005). John e Cremonini apud Resende, Barros e Medeiros (2011, p.5) definem manutenção "...como um conjunto de serviços realizados na edificação e suas partes durante a sua vida útil, com o objetivo de manter seus desempenhos iniciais". Burns apud Vanier (2000) menciona que o termo "manutenção" normalmente abrange uma ampla gama de atividades planejadas e não planejadas utilizadas para "preservação dos ativos e de seus serviços em condições e de acordo com o propósito para o qual foi originalmente destinado". Por outro lado, maximizar ou estender a vida útil da edificação e de seus sistemas é outra importante função da manutenção (NASA, 2008) como mostrado na figura 1.4 .

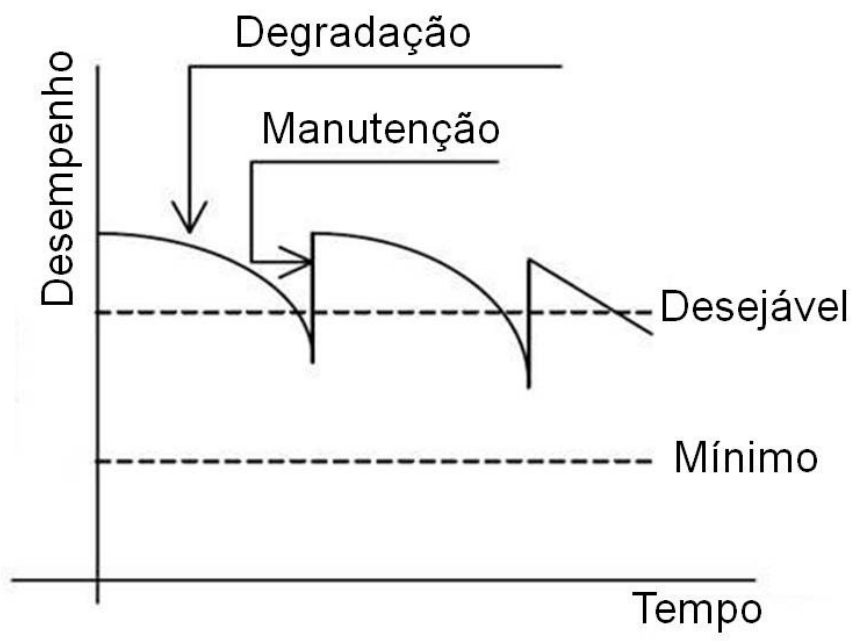

Figura 1.4 - A influência da manutenção na vida útil Fonte: RESENDE, BARROS e MEDEIROS, 2011, adaptada 
A vida útil e a durabilidade de um ativo estão diretamente relacionados. Resende, Barros e Medeiros (2011) esclarecem que durabilidade conforme a ASTM E632-82 é "..a capacidade de um produto, componente, montagem ou construção manter-se em serviço ou em utilização, ou seja, é capaz de desempenhar as funções para as quais foi projetado durante um determinado período de tempo". A The Canadian Standards Association define em seu Guideline on Durability in Buildings, revisão 2001, que durabilidade é a habilidade de um edifício ou qualquer de seus componentes desempenhar as funções requeridas, nas condições ambientais previstas, por um período de tempo mínimo especificado e sem custo de manutenção ou reparos imprevistos (HOFF, 2009). Segundo John et al. (2011, p. 2),

[...] a durabilidade, expressa pela distribuição de vida útil de um conjunto de componentes, desempenha uma função importante para obtenção de uma construção sustentável. Ao relatar conceitos de construção sustentável do ponto de vista de diferentes países, levantados pela comissão W82 do CIB, Bordeau (1999) observa que em algumas línguas como o alemão, finlandês, romeno ou francês, "sustentável" é traduzido como "durável".

De Simone e Poppof apud John et al. (2011) mencionam que essa analogia é pertinente uma vez que "uma forma de aumentar a produtividade dos recursos é aumentar a vida útil dos produtos".

A manutenção predial, ao estender a vida útil ou a durabilidade da edificação e seus componentes, colabora efetivamente para diminuição da carga ambiental sobre a natureza uma vez que menos recursos naturais são exigidos para novas construções, diminuindo as emissões para a atmosfera, consumo de energia, água, etc. Além disso, a manutenção predial está bastante relacionada à operação do edifício, o que a coloca em condições de produzir excelentes resultados em termos de bem-estar, saúde, segurança e satisfação aos ocupantes do edifício.

Lutzkendorf e Lorenz (2005) enfatizam que a satisfação e o atendimento das necessidades dos usuários e ocupantes também são aspectos chave para a definição dos edifícios sustentáveis. Um tópico que se destaca é a importância do bem-estar dos seus usuários, tema este diretamente ligado à qualidade dos serviços de operação e manutenção. A influência que quesitos como conforto térmico, acústico, visual, qualidade do ar interno e qualidade da água potável tem sobre a produtividade das pessoas é cada vez mais estudada.

Além de contribuir efetivamente para a durabilidade e extensão da vida útil do edifício, na fase de Operação/Uso a gestão de manutenção dos ativos também 
colabora efetivamente para a sustentabilidade do edifício quando (HILL; BOWEN, 1997; SEV, 2009; SAPP, 2010):

- Assegura que a edificação cumpre suas funções conforme projetada e construída;

- A função e o desempenho requerido para todos os sistemas prediais são mantidos com disponibilidade, confiabilidade e segurança. Perdas, desgastes, paradas repentinas de funcionamento e gastos com reparos são sob controle e num patamar adequado;

- Faz uso eficiente de energia e água;

- Minimiza o uso de materiais, produtos e a geração de resíduos, principalmente aqueles com características tóxicas (p.ex., tintas, vernizes);

- Minimiza as emissões poluentes para o ar, água e solo;

- Assegura padrões saudáveis e adequados de produtividade e desempenho para seus usuários, por meio de ações de controle do bemestar, conforto acústico, visual, térmico, qualidade do ar e da água dos ambientes de trabalho e convivência;

- Elimina condições inseguras e insalubres;

- Maximiza o emprego de materiais e produtos de baixa energia embutida, incorporando, quando possível, materiais e produtos reciclados;

- Minimiza a emissão de gases que colaboram para o efeito estufa.

\subsubsection{Justificativa do presente trabalho}

Este trabalho procura discorrer sobre as diversas estratégias de manutenção que podem ser aplicadas a um sistema de ar condicionado de grande porte, de expansão indireta com condensação a água, com destaque para a manutenção preventiva baseada em condição. Baseada em medição de parâmetros de máquinas e análises comparativas, essa estratégia tem como conceito intervir nos ativos somente quando esses apresentam alguma anomalia que pode contribuir para sua quebra ou retirada de serviço. Esse tipo de estratégia teve especial crescimento e aplicação a partir da década de 1980 , devido ao surgimento de instrumentos de 
medição de grande precisão e com programas especializados em coleta e tratamento de dados. A cada dia esses instrumentos encontram mais e maiores campos de aplicação e representam atualmente o estado da arte em manutenção.

A escolha de um sistema de ar condicionado como o mencionado para exemplo de aplicação de estratégias de manutenção e técnicas preditivas se justifica por várias razões, tais como:

- composto por diversos equipamentos mecânicos de variadas funções e importância, possuem sistemas ou equipamentos elétricos de alimentação de energia acessórios que também são essenciais para funcionamento do sistema como um todo. Sistemas como esse normalmente possuem capacidades que exigem alimentação elétrica em média tensão, o que provoca a adoção de componentes elétricos de classe de tensão elevada e necessita de cuidados especiais de manutenção. Tanto os sistemas mecânicos como os elétricos possuem componentes de expressivo valor $\mathrm{e}$ de variados graus de tecnologia, desde as mais simples até as mais sofisticadas, cuja quebra ou perda causa grande impacto econômico, além de parada, parcial ou completa, do sistema de ar condicionado, com consequências imprevisíveis. Além disso, a aplicação das estratégias de manutenção sobre um sistema desse tipo, com uma variedade muito grande de componentes, que são utilizados em diferentes aplicações em outros sistemas prediais de diferentes tipos, proporciona um aprendizado que pode ser transferido aos mesmos sem praticamente nenhuma restrição e com significativa eficiência;

- de alto custo de implantação, talvez seja individualmente o sistema de valor mais alto entre os sistemas prediais, as atividades de manutenção sobre o mesmo se justificam como forma de conservação de um patrimônio essencial para o edifício;

- sua grande importância para a sustentabilidade do edifício. Talvez seja, dentre todos os sistemas prediais, aquele com maiores possibilidades de aplicação do conceito. Grande consumidor de recursos como mão de obra e materiais para manutenção, também é consumidor intensivo de energia e água. Seu mau funcionamento pode provocar mal-estar, danos à saúde e queda de produtividade dos trabalhadores. O bom desempenho de um sistema desse tipo depende da execução rotineira e contínua de 
atividades de manutenção, baseadas num planejamento bem elaborado e cuidadoso;

- com relação ao consumo de energia, esse tipo de sistema é responsável por cerca de 35 a 55\%, dependendo da estação do ano, de toda energia empregada num edifício. Assegurar que os equipamentos funcionem em acordo com as especificações e na faixa de desempenho previsto pode significar uma redução sensível de consumo de energia. De acordo com PECl apud Chimack, Aardsma e Novosel (2006), a aferição e calibração de sensores de temperatura e válvulas de controle de água gelada, ajuste dos parâmetros de máquinas, adaptação do funcionamento às condições operacionais requeridas podem levar a um aumento da eficiência entre $5 \mathrm{e}$ $30 \%$. Ainda de acordo com a mesma fonte, em torno de 15 a $20 \%$ dos gastos com energia podem ser reduzidos com a implantação de um programa de manutenção preventiva;

- manter esse sistema em funcionamento com confiabilidade e segurança é outro quesito fundamental. Com a manutenção preventiva baseada em condição a gestão de manutenção dos equipamentos do sistema de ar condicionado fica otimizada, as paradas devido falhas não previstas ou programadas são bastante diminuídas e a vida útil dos equipamentos é estendida. A disponibilidade aumenta, o que assegura aos usuários ambiente agradável e bem-estar;

- a qualidade do ar interno e o conforto térmico dos ocupantes do edifício são essenciais. Má qualidade do ar interior e falta de conforto térmico são comumente relacionados a uma combinação de fatores. Um desses, os procedimentos de manutenção, está associado a $75 \%$ dos edifícios com baixa qualidade do ar e pode acabar levando à síndrome dos edifícios doentes (CHIMACK; AARDSMA; NOVOSEL, 2006). Uma adequada manutenção pode evitar isso, por meio do ajuste conveniente dos volumes de trocas de ar do ambiente, evitando a existência de contaminantes próximos de tomadas de ar, substituindo filtros e limpando linhas de dutos de distribuição, serpentinas e gabinetes de fan-coils, ajustando sensores e controladores de temperatura e de ar, etc.

- as consequências da baixa qualidade de manutenção de um sistema de ar condicionado além de impactar na saúde das pessoas, leva a perdas para 
as empresas na forma de baixa produtividade dos seus colaboradores. Com respeito aos prejuízos que podem causar aos negócios de uma empresa, de acordo com o WBDG (2010) num edifício os gastos com salários de funcionários chegam a $84 \%$ dos custos totais de uma organização, enquanto o consumo de energia é de cerca de $1 \%$, e, manutenção e aluguel representam, respectivamente, 1\% e 14\%. Em virtude dessa situação, um ambiente de trabalho confortável e saudável, com adequada manutenção de seus sistemas, pode acarretar um aumento da produtividade cujo benefício pode superar os custos com as melhorias realizadas. A produtividade relacionada ao aumento da capacidade de trabalho, maior produção, é muito difícil de ser medida e calculada, porém aquela vinculada à menor absenteísmo, afastamento médicos, custos hospitalares, pode ser razoavelmente determinada. Para se ter uma idéia do montante da redução de custos e ganhos de produtividade que um ambiente saudável pode provocar, na tabela 1.1 são apresentados valores para os E.U.A. estimados por Fisk (2000). Os montantes indicados, apesar de uma considerável incerteza nas estimativas de ganhos de produtividade, representam ganhos bastante significativos (FISK, 2000).

Tabela 1.1 - Estimativa de ganhos potenciais de produtividade devido melhorias nas condições de conforto do ambiente interior - em 1996

\begin{tabular}{|c|c|c|}
\hline $\begin{array}{l}\text { Fontes de ganho de } \\
\text { produtividade }\end{array}$ & $\begin{array}{c}\text { Potencial anual de benefícios para a } \\
\text { saúde }\end{array}$ & $\begin{array}{l}\text { E.U.A. } \\
\text { Potencial anual } \\
\text { de economia ou } \\
\text { de ganhos de } \\
\text { produtividade } \\
\text { US\$ }\end{array}$ \\
\hline $\begin{array}{l}\text { Redução de doenças } \\
\text { respiratórias }\end{array}$ & $\begin{array}{l}16 \text { a } 37 \text { milhões de casos evitados de } \\
\text { resfriados ou gripes }\end{array}$ & 6 - 14 bilhões \\
\hline $\begin{array}{l}\text { Redução de alergias e } \\
\text { asmas }\end{array}$ & $\begin{array}{l}8 \% \text { a } 25 \% \text { de diminuição dos sintomas } \\
\text { entre os } 53 \text { milhões que sofrem com } \\
\text { alergias e } 16 \text { milhões que são asmáticos }\end{array}$ & 1 - 4 bilhões \\
\hline $\begin{array}{l}\text { Redução dos sintomas da } \\
\text { Síndrome dos Edifícios } \\
\text { Doentes }\end{array}$ & $\begin{array}{l}20 \% \text { a } 50 \% \text { de redução nos sintomas de } \\
\text { Síndrome dos Edifícios Doentes } \\
\text { frequentemente vivenciados no trabalho } \\
\text { por cerca de } 15 \text { milhões de trabalhadores }\end{array}$ & 10 - 30 bilhões \\
\hline $\begin{array}{l}\text { Melhoria do desempenho } \\
\text { devido ajustes da } \\
\text { temperatura ambiente e da } \\
\text { iluminação }\end{array}$ & Não aplicável & 20 - 160 bilhões \\
\hline
\end{tabular}

Fonte: FISK, 2000, adaptada 
De acordo com Che-Ani et al. (2009, p. 1157),

[...] o edifício sustentável é uma estrutura projetada, construída, renovada, operada, ou reutilizada de forma ecologicamente adequada e com aplicação eficiente de recursos. Edifícios sustentáveis são projetados para ir de encontro a certos objetivos, tais como, proteger a saúde de seus ocupantes; aumentar a produtividade dos funcionários; usar a energia, água, e outros recursos eficientemente; e reduzindo o impacto no meio ambiente.

Percebe-se que a manutenção predial de um modo geral e principalmente aquela voltada a sistemas de ar condicionado atendem plenamente aos requisitos de sustentabilidade de uma edificação.

Para melhor entendimento do conceito de sustentabilidade predial e como a sua manutenção pode colaborar para tão importante quesito, essa dissertação foi dividida em 5 capítulos.

No primeiro capítulo, esta introdução, se fez uma revisão dos efeitos da degradação do planeta sobre a natureza e o Homem. Também se faz uma revisão do conceito de sustentabilidade e da importância das atividades de manutenção para a durabilidade do edifício e seus sistemas, destacando-se a importância da manutenção em sistemas de ar condicionado para a sustentabilidade do edifício, conforto, saúde e segurança de seus ocupantes.

O segundo capítulo apresenta os objetivos pretendidos e a metodologia empregada, mencionando-se a aplicabilidade do trabalho na área de gerenciamento de facilidades e fonte de informações para o seu gestor.

No terceiro capítulo se faz a revisão das clássicas estratégias de manutenção, ou seja, corretiva e preventiva, com ênfase à manutenção baseada em condição e aos princípios da manutenção centrada em confiabilidade.

O quarto capítulo realiza a descrição das principais técnicas de manutenção preditiva que constituem um programa de manutenção baseada em condição. Nesse capítulo se utiliza como exemplos de aplicação da técnica os equipamentos que fazem parte de um sistema de ar condicionado de expansão indireta e condensação a água.

O quinto e último capítulo apresenta as considerações finais de todo o trabalho com comentários gerais sobre o tema da dissertação. 


\section{OBJETIVOS E METODOLOGIA}

\subsection{Objetivo da dissertação}

O presente trabalho possui dois objetivos gerais.

O primeiro é a caracterização das atividades de manutenção de um sistema de ar condicionado de grande porte, de expansão indireta e condensação a água, de um edifício de escritórios que colaboram para a sustentabilidade da edificação. Não só em relação ao aumento de sua vida útil ou durabilidade, mas também nos aspectos de conforto térmico para as pessoas e da qualidade do ar dos ambientes internos. É importante citar que o conceito de durabilidade adotado neste trabalho é o do Guideline on Durability in Buildings (CSA S478-95 - rev. 2001 - The Canadian Standards Association), ou seja, é a habilidade de um edifício ou qualquer de seus componentes desempenhar as funções requeridas, nas condições ambientais previstas, por um período de tempo mínimo especificado e sem custo de manutenção ou reparos imprevistos (HOFF, 2009).

O segundo objetivo geral consiste em oferecer ao profissional de gerenciamento de facilidades um trabalho com visão panorâmica das atividades de manutenção de sistemas prediais, tomando como exemplo o sistema de ar condicionado já mencionado, sem demasiada profundidade, mas suficiente para compreensão dos fundamentos técnicos e possibilidades de utilização.

Entre os objetivos específicos, podem ser mencionados:

a) Apresentar, de modo não extensivo, problemas ambientais do planeta, que sejam afetados pela construção e operação de edifícios e por seus sistemas;

b) Rever o conceito de sustentabilidade ambiental aplicado aos edifícios comerciais de escritórios;

c) Rever os conceitos clássicos relativos ao gerenciamento de manutenção predial, manutenção corretiva e preventiva;

d) Inserir as atividades de manutenção de sistemas de ar condicionado no contexto da sustentabilidade econômica, ambiental e social, destacando a 
manutenção preventiva baseada em condição como procedimento sine qua non de uma manutenção sustentável;

e) Rever os diversos tipos de testes preditivos de máquinas que fazem parte de um programa de manutenção preventiva baseada em condição, tomando como exemplo de aplicação um sistema de ar condicionado utilizado nos edifícios de escritórios.

Os itens (a) e (b) foram apresentados no primeiro capítulo desta dissertação, os itens (c) e (d) são tratados nos capítulo 3, enquanto o item (e) é tratado no capítulo 4. No próximo item se expõe a metodologia adotada nesta dissertação.

\subsection{Metodologia}

\subsubsection{Aspectos gerais}

Este trabalho aborda um sistema de ar condicionado como exemplo de aplicação de atividades de manutenção com intuito de colaborar para a sustentabilidade do edifício onde possa estar instalado.

A escolha desse tipo de sistema de ar condicionado, de expansão indireta e condensação a água, como exemplo para discorrer sobre manutenção baseada em condição e suas técnicas preditivas levou em conta:

- Sua complexidade, pois possui muitos e diversos equipamentos, com as mais variadas tecnologias;

- Sua operação e capacidade de ajustes, bastante eficiente e conhecida, atende a diferentes padrões de desempenho;

- Sua qualidade, consegue atender aos mais altos padrões de conforto térmico, fazendo que esteja presente nos melhores edifícios existentes no mundo.

Uma pesquisa de campo sobre condições gerais de manutenção de sistemas de ar condicionado, no país, encontraria menores dificuldades se tivesse como foco 
a qualidade e higienização do ar insuflado, por haver documentação da ABNT e ANVISA para tanto. Todavia, no que se refere à produção e distribuição de água gelada dos sistemas de produção indireta, não há extensa literatura técnica muito além dos manuais de fabricantes dos diversos componentes do sistema.

Do material consultado na revisão bibliográfica, uma boa parte apresenta demasiado detalhamento construtivo, mas com pouco acréscimo sob o olhar da gestão de manutenção.

\subsubsection{Método empregado}

Para obtenção das informações para elaboração da dissertação foi realizada revisão bibliográfica em livros, revistas do mercado, Internet, catálogos e artigos de periódicos científicos.

Por meio dessa revisão se procurou;

- Entender os conceitos e princípios essenciais da Sustentabilidade e como a manutenção de edifícios, principalmente de sistemas de ar condicionado, pode colaborar para a sustentabilidade da edificação;

- Descrever a conceituação clássica das estratégias de manutenção e suas práticas industriais, atualmente ainda pouco utilizadas no setor predial;

- Organizar e indicar a estratégia e as técnicas de manutenção baseadas em condição, que atualmente representa 0 estado da arte em manutenção, tomando como exemplo os ativos do sistema de ar condicionado mencionado, incluindo todos os seus acessórios elétricos.

Nos capítulos 3 e 4 se apresenta uma primeira introdução no que se refere ao conjunto de conceitos de manutenção em geral e da manutenção baseada em condição em particular, aplicados a um tipo específico de sistema de ar condicionado. No futuro, os mesmos conceitos podem ser aplicados a outros tipos de sistemas, como os de expansão direta, split-systems, VAV, VRF e várias outras inovações tecnológicas, como insuflamento pelo piso, teto resfriado e etc. 


\section{ESTRATÉGIAS DE MANUTENÇÃO APLICADAS A SISTEMAS PREDIAIS}

Os edifícios são compostos por inúmeros e complexos sistemas, que se complementam com a finalidade de proporcionar um ambiente de trabalho produtivo, confortável, saudável e seguro para seus ocupantes. Para tanto, é imprescindível que uma grande variedade de serviços e recursos de manutenção sejam empregados, tais como, mão de obra especializada, planejamento, gestão administrativa, peças e máquinas sobressalentes, etc. Num prédio com bom nível de manutenção, tudo deve funcionar muito bem e por muito tempo. O desenvolvimento de estratégias de manutenção apropriadas para cada sistema predial é essencial para tornar o ambiente construído sustentável.

\subsection{Manutenção - Termos e definições importantes}

Moubray (1997) esclarece que os componentes, equipamentos e sistemas possuem uma resistência à perda de desempenho. Uma vez implantados iniciam o cumprimento da função para o para qual foram projetados e implantados e ficam sujeitos a desgastes ou estresses variados ao longo de sua vida útil, cujos efeitos acabam por se combinar e levam à diminuição dessa resistência, e, consequentemente, à perda de desempenho. Esses processos inevitáveis de enfraquecimento e perda de desempenho podem ser controlados por ações de manutenção. Os equipamentos readquirem resistência a estresses, retomam antigos desempenhos e tem sua vida útil prolongada.

Diversos termos empregados na gestão de componentes, equipamentos e sistemas encerram conceitos-chave para compreensão e desenvolvimento das atividades de manutenção. Dentre os mais importantes, destacam-se para os fins da presente dissertação: 


\subsubsection{Ativo ou item}

Termos generalistas dados a estruturas, componentes, equipamentos e sistemas que desempenham uma ou mais funções numa edificação. É uma forma rápida usada para mencionar tudo aquilo que esteja sob gestão de manutenção. Ex.: edifício, bomba, chiller, filtro, motor, sistema elétrico, etc (IAEA, 2007).

\subsubsection{Função de um ativo}

É a finalidade para qual um determinado item foi concebido ou projetado. Como exemplo pode-se considerar uma bomba de água. Sua função principal (ou primária) é bombear (transferir) água de um determinado ponto para outro (MOUBRAY, 1997).

\subsubsection{Desempenho}

É a capacidade de atender ou cumprir requisitos especificados com uma determinada competência ou eficiência. De acordo com Gonçalves e Graça (1986), o conceito de desempenho está relacionado à durabilidade e à capacidade de um sistema realizar sua função e, consequentemente, contribuir para que o sistema também permaneça em funcionamento adequado, durante o período de utilização considerado e à compatibilização dos sistemas às exigências dos usuários, independentemente dos componentes a serem usados. No caso da bomba de água, além de possuir a função de transferir água de um determinado ponto a outro, deve também apresentar desempenho mínimo aceitável em termos de volume de água bombeada e pressão (funções secundárias). Durante sua vida útil os ativos estão sujeitos a vários estresses que levam à deterioração de sua condição e que levam à perda de desempenho. Uma vez que essa situação é inevitável, quando um item é colocado em serviço o mesmo deve possuir capacidade de desempenhar sua 
função com certa folga em relação ao desempenho mínimo requerido (MOUBRAY, 1997).

\subsubsection{Defeito ou Falha Potencial}

Um ativo está numa condição de defeito ou de falha potencial, quando apresenta sintomas de degradação que não provocam a sua perda de função (não existe quebra) e seu desempenho está acima da capacidade mínima requerida (MOUBRAY, 1997; FILHO, 2000).

\subsubsection{Falha ou Falha Funcional}

Quando um item perde a capacidade de realizar sua função devido quebra ou porque seu desempenho é menor que a capacidade mínima requerida (MOUBRAY, 1997; FILHO, 2000).

\subsubsection{Disponibilidade}

Representa os esforços e qualidade na condução dos serviços de manutenção. É a probabilidade de que um item possa estar disponível para utilização em um determinado momento ou durante um determinado período de tempo. Capacidade de um ativo para desenvolver sua função em um determinado momento ou durante um determinado período de tempo, nas condições e rendimentos definidos. A disponibilidade de um item não significa que esteja funcionando, mas que encontra-se em condições de funcionar. Seu oposto é o termo indisponibilidade (FILHO, 2000). 


\subsubsection{Confiabilidade}

É a probabilidade de um ativo funcionar corretamente em condições definidas durante um determinado período de tempo ou de ainda estar em condições de trabalho após um determinado período de funcionamento. É a capacidade de um item para realizar sua função específica nas condições e com o desempenho definidos durante um período de tempo determinado. Em manutenção é um conceito associado a jornada, missão ou meta (de produção, de anos de trabalho, etc) (FILHO, 2000).

\subsubsection{Mantenabilidade}

Mantenabilidade, manutenibilidade ou manutenabilidade é a probabilidade de que um item avariado possa ser colocado novamente em seu estado operacional, em um período de tempo predefinido, quando a manutenção é realizada em condições determinadas e é efetuada com os meios e procedimentos estabelecidos. Facilidade com que pode realizar-se uma intervenção de manutenção (FILHO, 2000).

\subsection{Estratégias de manutenção}

A British Standards Institution, em sua versão de 1991, estabelece que a manutenção predial pode ser definida como "combinação de todas as técnicas e ações administrativas, incluindo ações de supervisão, destinados a manter ou restaurar um ativo, a um estado em possa desempenhar uma função requerida" (WOOD, 2005, p. 292).

Fatores tais como, consequências da falha (meio ambiente, segurança, saúde, econômicos), cultura de manutenção da organização, recursos tecnológicos, de mão de obra e disponibilidade financeira, interferem na adoção das diferentes 
estratégias de manutenção disponíveis. Além disso, as estratégias podem ser mais ou menos consistentes em acordo com cada equipamento, sistema ou edifício.

Apesar dos diversos nomes encontrados para gestão de ativos, basicamente todos eles se enquadram em três conceitos estratégicos principais, ou seja, manutenção corretiva, preventiva e centrada em confiabilidade (CNSC, 2007; IAEA, 2003, 2007; NASA, 2008).

\subsubsection{Manutenção Corretiva ou Reativa}

Nessa estratégia o item é reparado ou substituído somente após entrar em estado de falha. Admite dois tipos de gestão, ou seja, planejada, resultado de uma análise consciente e deliberada, ou não planejada (NASA, 2008).

\subsubsection{Manutenção Corretiva Planejada ou RTF (Run-to-Failure ou Que Funciona até Falhar)}

Técnica de gestão aplicada a itens após sua a falha e sem qualquer medida de prevenção contra ela. Não é uma técnica cujo resultado seja devido má gestão ou falta de manutenção, mas sim deliberada e conscientemente planejada. Nesse tipo de gestão quando o item falha deve necessariamente ser substituído por outro, podendo, posteriormente, ser reparado ou não (MECHEFSKE, 2005; CHIMACK; AARDSMA; NOVOSEL, 2006; SULLIVAN et al., 2010). Porém, segundo Bengtsson (2004), o item em falha não precisa ser obrigatoriamente substituído e de imediato. Se não houver um comprometimento da função do sistema como um todo, o item pode ser reparado de modo planejado num momento mais adequado. De maneira geral, a técnica RTF pode ser aplicada quando (MECHEFSKE, 2005; CHIMACK; AARDSMA; NOVOSEL, 2006; SULLIVAN et al., 2010):

- Não existem consequências econômicas, de segurança e operacionais.

- A parada de funcionamento do item é evidente.

- O custo de prevenção da falha é mais alto que a substituição.

- O custo do item e de sua substituição é baixo. 
- A taxa de falhas é baixa.

- O tempo de substituição é pequeno.

- Os transtornos causados, em termos de alocação de mão de obra para substituição, são mínimos.

E ainda:

- Em alguns casos onde o item é redundante.

Itens típicos onde esta estratégia pode ser aplicada: manômetros, indicadores de temperatura, compressores herméticos de pequena capacidade, placas de circuitos eletrônicos, computadores com redundância em tempo real.

$\mathrm{Na}$ tabela 3.1 temos os aspectos positivos e negativos da adoção ou não dessa estratégia.

Tabela 3.1 - Aspectos positivos e negativos da Manutenção Corretiva RTF

\begin{tabular}{ll}
\hline \multicolumn{1}{c}{ Aspectos Positivos } & \multicolumn{1}{c}{ Aspectos Negativos } \\
\hline - Baixo custo de manutenção. & Estocagem dos itens sujeitos a \\
- Baixo nível de controle. & substituição. \\
- Liberação de mão de obra (planejamento/ & - Garantia de qualidade dos itens \\
execução de manutenção). & estocados. \\
\hline
\end{tabular}

Fonte: CHIMACK; AARDSMA; NOVOSEL, 2006; SULLIVAN et al., 2010; NASA, 2008, adaptadas

\subsubsection{Manutenção Corretiva Não Planejada (MC)}

Manutenção corretiva não planejada ou simplesmente, manutenção corretiva, como é mais usual, também é um tipo de gestão aplicada a itens após sua falha. Pode ser um tipo de gestão baseada em "conserta-quando-quebra", sem qualquer preocupação ou avaliação da pertinência da adoção de tal técnica, e/ou devido à impossibilidade da prevenção de todas as falhas, mesmo na existência de um programa de manutenção preventiva de ótima qualidade (DESHPANDE; MODAK, 2002).

Caso seja uma estratégia conscientemente adotada de "conserta-quandoquebra" pode gerar grandes prejuízos a médio e longo prazo. Além do desempenho inferior, que causa gastos de energia e insumos de forma improdutiva e desnecessária, também leva a maiores custos de manutenção, uma vez que o 
reparo de um item com falha normalmente requer muito mais trabalho e material em relação ao reparo feito antes do item falhar. Uma falha num item primário pode causar danos num secundário, num efeito cascata que contribui ainda mais para diminuição da vida útil do item sob gestão de manutenção. É também essencial considerar os custos e as consequências da paralisação dos serviços fornecidos, que podem muitas vezes ser muito superiores ao custo do reparo, sem falar nos aspectos de segurança (MECHEFSKE, 2005; CHIMACK; AARDSMA, NOVOSEL, 2006; SULLIVAN et al., 2010). Se adotada a gestão baseada em "conserta-quandoquebra" mencionada, podem-se ter os aspectos positivos e negativos descritos na tabela 3.2.

Tabela 3.2 - Aspectos positivos e negativos da Manutenção Corretiva Não Planejada

\begin{tabular}{|c|c|}
\hline Aspectos Positivos & Aspectos Negativos \\
\hline $\begin{array}{l}\text { - Não existe paralisação do ativo entre as } \\
\text { falhas. } \\
\text { - É bem aceita pelo pessoal de } \\
\text { manutenção. } \\
\text { - Fácil de justificar. } \\
\text { - Dispensa equipe de monitoramento de } \\
\text { equipamentos e sistemas. } \\
\text { - Praticamente elimina a necessidade de } \\
\text { equipe de planejamento de serviços. }\end{array}$ & 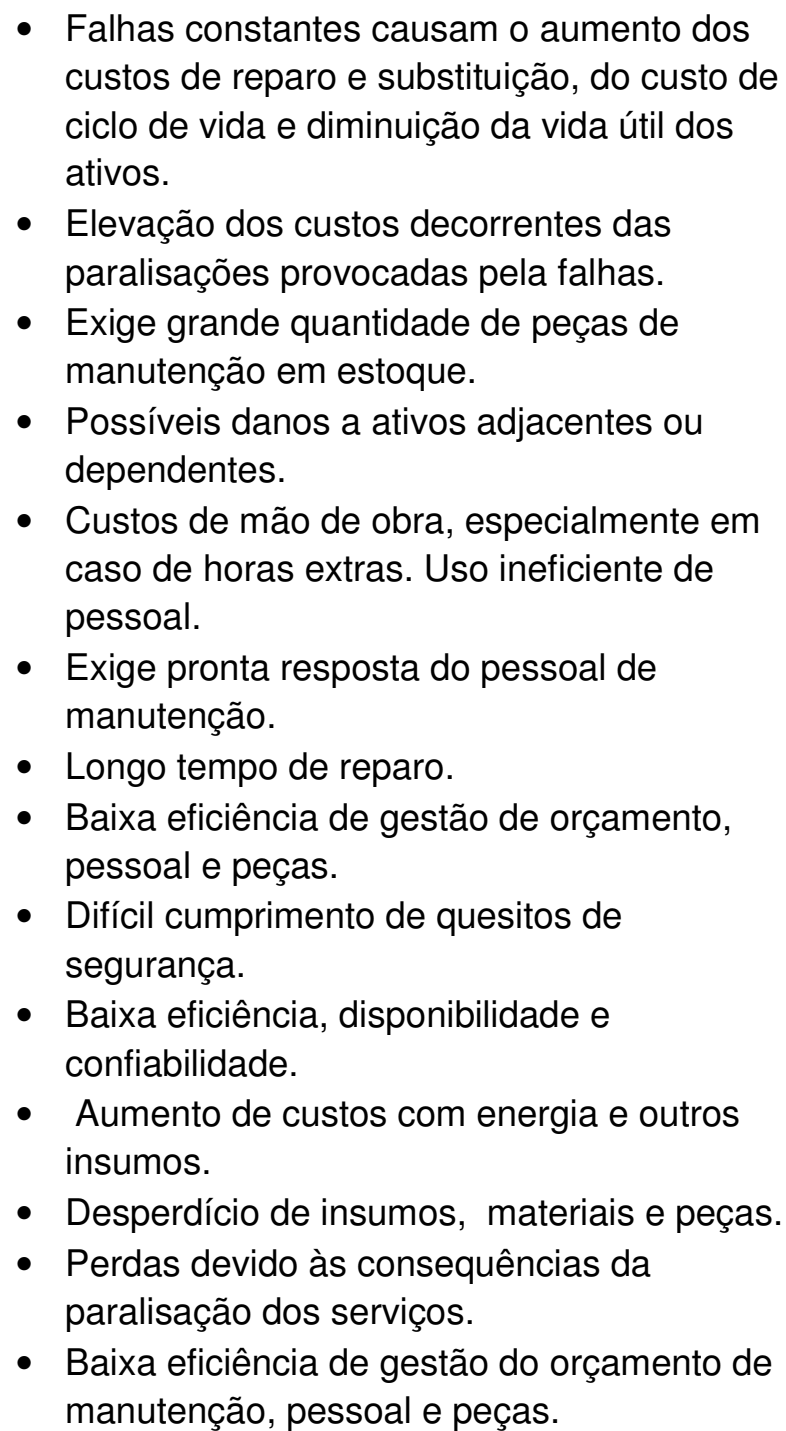 \\
\hline
\end{tabular}

Fonte: CHIMACK; AARDSMA, NOVOSEL, 2006; SULLIVAN et al., 2010; NASA, 2008, adaptadas 


\subsubsection{Manutenção Preventiva (MP)}

Essa estratégia tem como premissa agir sobre ativos que estejam em plenas condições operacionais (função e desempenho) e antes que entrem em falha. Todas as ações são executadas com a finalidade de eliminar defeitos latentes ou incipientes. Como consequência, melhora a logística de execução dos serviços, reduz a quantidade de falhas, diminui o custo de manutenção e a quantidade de serviços não planejados, mitiga interrupções intempestivas do serviço, bem como a vida útil dos componentes, equipamentos e sistemas é prolongada (WORSHAM, 2011; CHIMACK; AARDSMA; NOVOSEL, 2006).

A estratégia de manutenção preventiva admite três técnicas de gestão: periódica, baseada em condição e centrada em confiabilidade.

\subsubsection{Manutenção Preventiva Periódica (MP-P)}

Esse tipo de gestão de manutenção possui duas características principais (SULLIVAN et al., 2010; NASA, 2008):

- Sua execução é realizada em intervalos regularmente definidos, seja em termos de tempo (horas, dias, datas) ou de ciclos de trabalho/produção (volume, quantidade, quilometragem, etc), e;

- Não existe qualquer investigação ou conhecimento prévio a respeito do estado de degradação em que se encontra o componente, equipamento ou sistema, a menos que a intervenção em andamento seja resultado de inspeção preventiva anterior.

Na manutenção preventiva periódica ou sistemática são realizadas atividades diversas, tais como, inspeção, checagem, limpeza, lubrificação, pintura e substituição de pequenas peças. Caso se encontre alguma anomalia em equipamentos e sistemas durante a execução desse tipo de manutenção, ajustes e reparos são feitos imediatamente ou são programados para execução futura, mas sempre antes que $o$ item entre em falha (NASA, 2008). 
Nesse tipo de gestão a periodicidade das intervenções é baseada em taxas médias de falhas e nos tempos ou ciclos de trabalho médios entre falhas. Parte do princípio que essas variáveis podem ser determinadas estatisticamente, sendo possível estabelecer o intervalo entre as tarefas de manutenção e escolher o melhor momento para reparar, ajustar ou substituir uma peça ou equipamento sujeitos a desgaste antes da falha. Porém, no início de funcionamento da instalação, não é possível estabelecer a taxa de falhas, uma vez que os equipamentos não possuem suficiente tempo de operação para que as taxas sejam encontradas. Nesse caso é bastante comum seguir orientações de manuais de fabricantes de equipamentos ou mesmo estabelecer a frequência de intervenções baseados na experiência do pessoal técnico. Quando o padrão de falhas é bem conhecido, estável, é uma estratégia que oferece bons resultados a custo adequado.

Ocorre que numa instalação existem variados equipamentos com características construtivas também variadas. Equipamentos mais novos, mesmo com características similares, juntamente com outros mais antigos. Devido a essa situação, muitos equipamentos exibem taxa de falhas constante, enquanto outros apresentam randômica, aleatória, de difícil estabelecimento de valor. Mesmo equipamentos similares podem não apresentar taxas de falhas semelhantes, uma vez que os desgastes e usos podem ser diferenciados. Além disso, nem sempre os processos onde os equipamentos e sistemas estão envolvidos são razoavelmente constantes e podem estar sujeitos à variação acentuada de carga, estresse e velocidade, provocando também taxas de falhas variáveis. Mesmo para itens com padrão de falhas constantes, o valor médio da taxa de falhas admite uma variação em torno de seu valor central. Se basear em recomendações de fabricantes e de pessoal técnico para determinar a frequência de intervenções de manutenção, muitas vezes fundamentados em dados conservadores, pode provocar excesso de atividades e aumento de custos. Em todas essas situações existe o risco de intervir no equipamento sem necessidade ou de a falha ocorrer apesar do cumprimento do cronograma de intervenções. Na manutenção preventiva periódica cerca de 50 a $70 \%$ de todos os trabalhos podem ser desnecessários. Os equipamentos são frequentemente retirados de serviço para as manutenções de rotina, o que muitas vezes paralisa o funcionamento de uma planta ou processo. (NASA, 2008; SULLIVAN et al., 2010; CHIMACK; AARDSMA; NOVOSEL, 2006). 
Apesar desses aspectos negativos, não existem dúvidas quanto à eficácia da técnica em relação à estratégia de manutenção corretiva. Quando todas as restrições estão convenientemente entendidas e contornadas, a implantação e a gestão da manutenção preventiva periódica colabora efetivamente para diminuição da degradação e de falhas, aumentando a vida útil, a disponibilidade e a confiabilidade dos ativos sob gestão. Seus aspectos positivos em relação à manutenção corretiva podem ser vistos na tabela 3.3. Além dos aspectos positivos mencionados, destacam-se a redução de cerca de $30 \%$ nos custos com horas extras e de 12 a 18\%, pelo menos, dos custos de manutenção em relação à manutenção corretiva (SULLIVAN et al., 2010; CHIMACK; AARDSMA; NOVOSEL, 2006).

Tabela 3.3 - Aspectos positivos e negativos da Manutenção Preventiva Periódica

\begin{tabular}{|c|c|}
\hline Aspectos Positivos & Aspectos Negativos \\
\hline 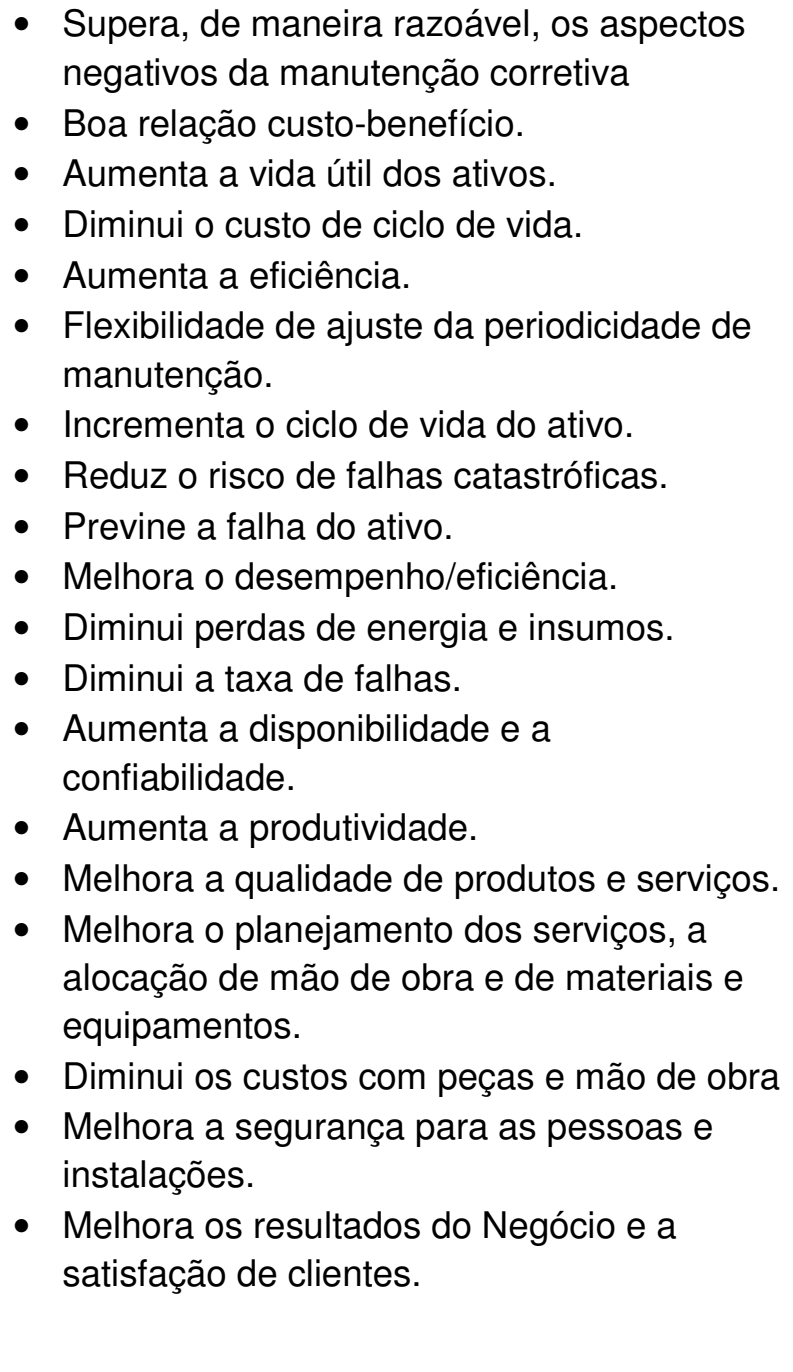 & $\begin{array}{l}\text { - O processo produtivo sofre freqüentes } \\
\text { interrupções. O tempo operacional do } \\
\text { ativo é reduzido. } \\
\text { - A manutenção preventiva é realizada } \\
\text { independente de ser necessária ou não. } \\
\text { - Restrições operacionais de produção } \\
\text { levam à postergação das manutenções. } \\
\text { - Determinação dos intervalos de } \\
\text { manutenção com base em informações } \\
\text { de fabricantes e vendedores. } \\
\text { - As falhas catastróficas ainda podem } \\
\text { - Ucontecer } \\
\text { - } \text { Pso intensivo de mãveis danos acidentais aos } \\
\text { componentes na realização de } \\
\text { manutenções desnecessárias. } \\
\text { - Aplicação/substituição de materiais } \\
\text { desnecessária em muitos casos. } \\
\text { - Exige muito planejamento de serviços e } \\
\text { administração de materiais. } \\
\text { - Grande quantidade de equipamentos e } \\
\text { materiais em estoque. } \\
\text { - } \text { Incremento de custos desnecessários } \\
\text { com materiais e mão de obra. } \\
\text { durante a execução de reparos devido a } \\
\text { erros humanos e/ou defeitos em materiais } \\
\text { novos. }\end{array}$ \\
\hline
\end{tabular}

Fonte: CHIMACK; AARDSMA; NOVOSEL, 2006; SULLIVAN et al., 2010; NASA, 2008, adaptadas 


\subsubsection{Manutenção Preventiva Baseada em Condição (MP-BC)}

A manutenção preventiva baseada em condição (MP-BC), também conhecida como Manutenção Preditiva (MPd) ou Manutenção Baseada em Monitoramento de Condições, é comumente conhecida língua inglesa como Condition-Based Maintenance (CBM), Predictive Maintenance (PdM) ou Predictive Testing and Inspection (PT\&I). Seu desenvolvimento aconteceu principalmente nos últimos 30 anos, devido ao desenvolvimento de estudos, softwares e de aparelhos de coleta, tratamento e interpretação de dados de máquinas, bem como à introdução dos computadores no dia-a-dia das áreas de manutenção.

Diferentemente da manutenção preventiva periódica, que executa serviços no ativo mesmo que não existam defeitos aparentes, a gestão de manutenção preventiva baseada em condição somente realiza intervenções em equipamentos após a constatação de um defeito real e da avaliação da evolução de sua deterioração. Esse tipo de manutenção consiste na inspeção e medição (monitoramento) de parâmetros de funcionamento de máquinas e sistemas por meio de aparelhos específicos, especialmente desenvolvidos para essa finalidade. Visto que todos os ativos se deterioram com o uso, por meio desses aparelhos é possível acompanhar a evolução de um defeito ao longo do tempo, avaliar sua tendência de degradação e escolher o melhor momento para aplicação de ações de correção antes da falha (IAEA, 2007). Moubray (1997) exemplifica isso por meio da curva P-F mostrada na figura 3.1.

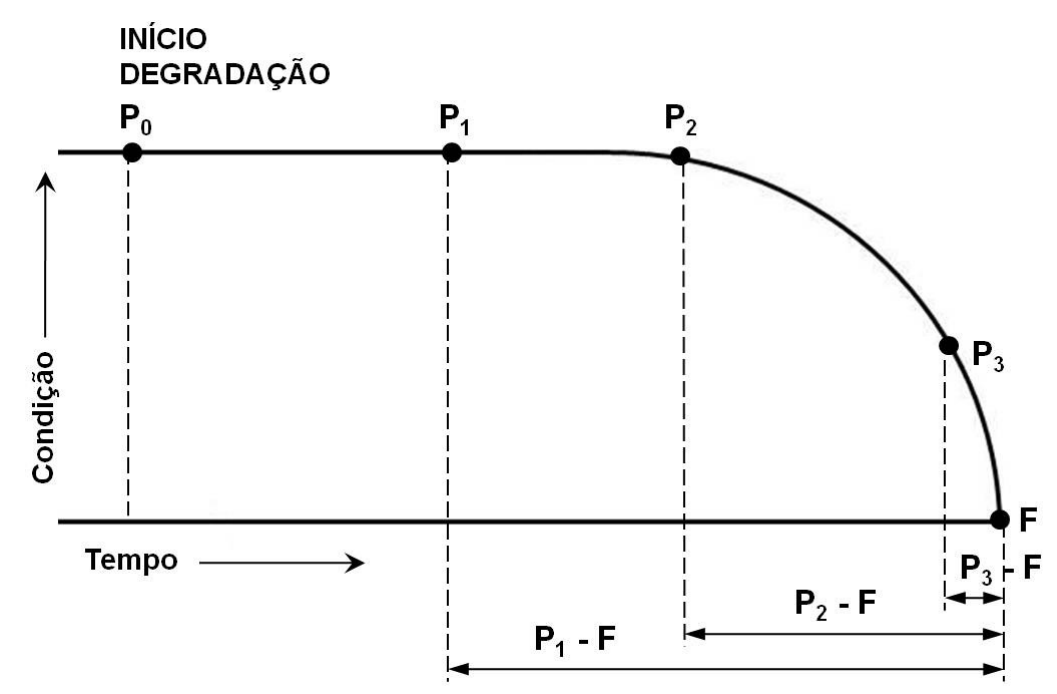

Figura 3.1 - Curva P-F

Fonte: MOUBRAY, 1997, adaptada 
Num determinado momento um defeito começa a ocorrer, mas ainda não é detectável. Após um período de tempo esse defeito evolui em magnitude, o que torna possível sua detecção e acompanhamento ao longo do tempo (pontos $P_{1}, P_{2}$, e $\mathrm{P}_{3}$ da curva). Se nenhuma intervenção de manutenção for feita, o defeito continua a evoluir até a falha (ponto F). Note-se que à medida que o tempo passa o defeito evolui cada vez mais rapidamente (aumenta a taxa de inclinação da curva).

$\mathrm{Na}$ MP-BC várias tecnologias são utilizadas. Normalmente são realizadas inspeções e testes preditivos, tais como, medição e análise de vibrações, análises de óleos lubrificantes e isolantes, termografia, medições de isolamento em equipamentos elétricos, análise de ultrasom, entre outros. Os dados coletados são então registrados e comparados com históricos existentes, dados de referência fornecidos por normas e experiência de pessoal técnico, desenhos e manuais de fabricantes, etc, de modo a checar a existência de defeito e respectiva tendência de evolução. Caso seja encontrado algum defeito com taxa elevada de degradação, uma ordem de serviço é emitida e o reparo efetuado antes que ocorra a falha. Caso o parâmetro esteja em condições normais, ou com uma taxa baixa ou estável de degradação, numa próxima inspeção passa por nova medição para fins de checagem de seu estado de deterioração (IAEA, 2007; NASA, 2008). Os resultados encontrados levam também a reavaliar o programa de inspeções. Na medida em que as tendências de deterioração são avaliadas, as frequências de inspeções podem ficar sujeitas a alterações, podendo aumentar ou não e até diminuir.

A implantação da MP-BC em geral parte da constatação de que a estratégia de manutenção preventiva periódica não consegue atingir os patamares de eficiência, custos, disponibilidade e confiabilidade necessários para um processo. Visto que a MP-BC significa uma evolução significativa em relação à manutenção corretiva e preventiva periódica, em muitas situações não existem dados disponíveis, o pessoal envolvido ainda não possui a suficiente familiarização com os conceitos e técnicas, nem é claro o contexto dos processos que envolvem os ativos. Além disso, em virtude de seu custo e da necessidade de supervisão e controle bastante desenvolvidos, é recomendável iniciar a implantação da MP-BC pelos ativos mais importantes da instalação. Nessas ocasiões o uso de fluxogramas qualitativos de decisão como o mostrado na figura 3.2 pode ser aplicado e uma avaliação sucinta do processo e seus ativos pode ser realizada, de maneira a iniciar a implantação de uma manutenção mais efetiva (MÁRQUEZ et al., 2009). Esse 
fluxograma tem como objetivo classificar os ativos para manutenção conforme uma escala de prioridades ABC, onde "A" é classificação mais relevante e "C", a menor.

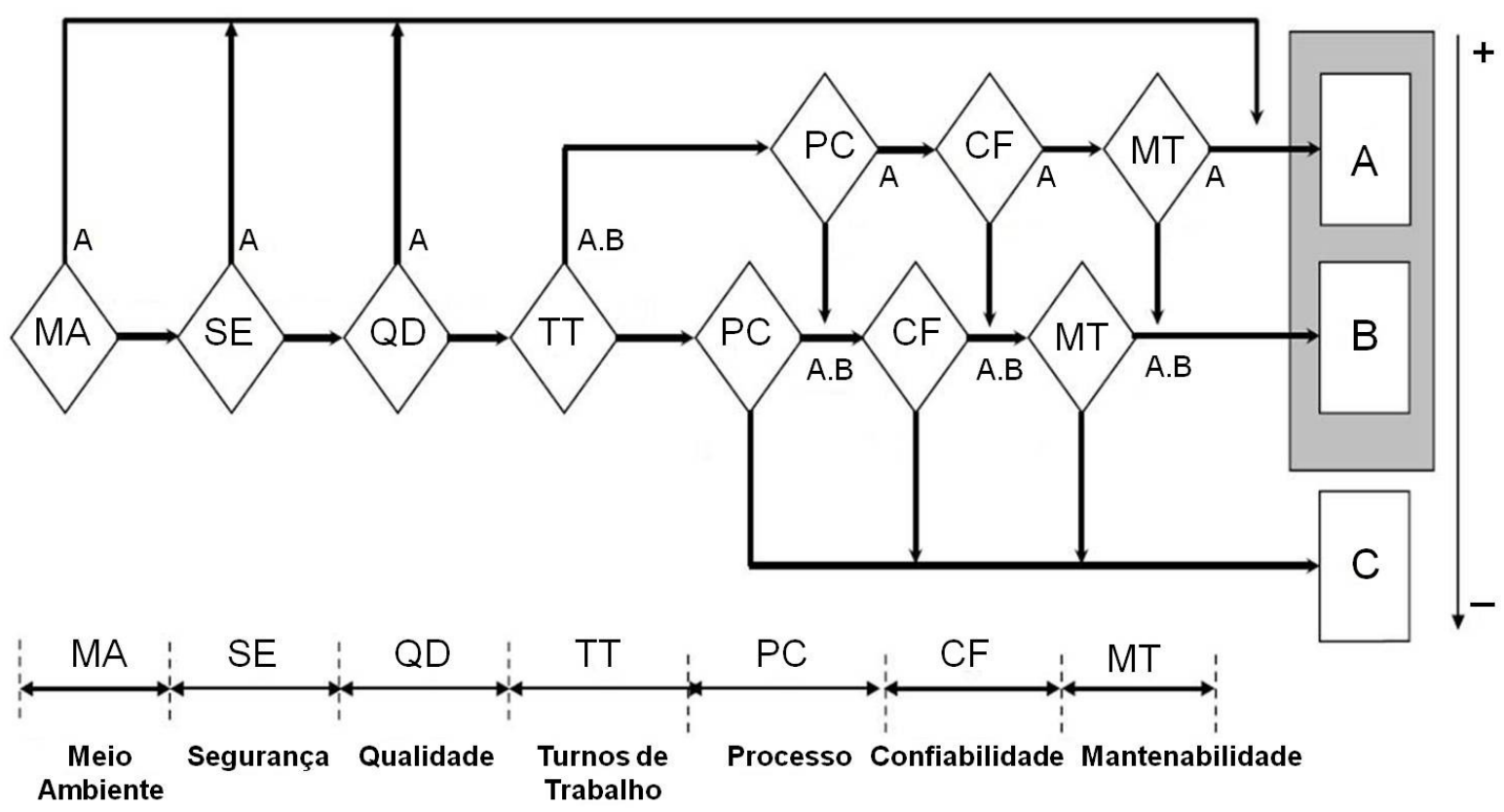

Figura 3.2 - Fluxograma de decisão para classificação de ativos para manutenção Fonte: Márquez et al., 2009, adaptada

Por meio da tabela 3.4 e iniciando pelo critério meio ambiente (MA) pode-se conduzir a avaliação de cada um dos ativos de interesse. Após o término do exame do primeiro critério passa-se ao segundo, segurança (SE) e assim sucessivamente. 
Tabela 3.4 - Critério para classificação $A B C$ de ativos para manutenção

\section{MA - Meio Ambiente:}

O impacto sobre o meio ambiente de um determinado ativo é o primeiro aspecto a ser considerado no fluxograma. Um ativo é considerado com classificação "A" se causar um importante impacto ambiental externo (fora das fronteiras da empresa) no caso de sua manutenção não ser realizada adequadamente. Impacto ambiental externo significa que a empresa deve comunicar as autoridades locais sobre o incidente e adotar planos de contingência específicos. A classificação "B" é aplicada a Itens cuja falha produz danos ambientais dentro das fronteiras da empresa e que podem ser resolvidos sem consequências para a comunidade externa. Classificação "C" é relativa a ativos que não causam danos ao meio ambiente em caso de falha.

\section{SE - Segurança:}

$\mathrm{Na}$ sequência é o próximo aspecto a ser analisado. ativos com classificação "A" são aqueles cuja falha pode provocar acidentes que levam a lesões temporárias ou permanentes numa pessoa ou que levam a afastamento temporário ou permanente do funcionário de seu local de trabalho. Classificação "B" define os ativos que ao falhar provocam lesões menores às pessoas sem gerar incapacidade temporária ou permanente ou que não causam o afastamento do funcionário de seu local de trabalho. Ativos cuja falha não causa riscos à segurança são classificados como " $\mathrm{C}$ ".

\section{QD - Qualidade:}

A classificação "A" é aplicada a ativos que ao falhar provocam perdas de qualidade que podem provocar um impacto externo importante, ou uma imagem de mercado muito negativa de seus consumidores. As classificações "B" e "C" podem ser determinadas para Ativos que quando não adequadamente mantidos, podem sofrer falhas que produzem impactos internos ou nada causam, respectivamente.

\section{TT - Turnos de trabalho:}

Neste caso, ativos com três turnos de trabalho por dia são classificados como "A". Dois turnos, "B", e, um turno, "C".

\section{PC - Processo:}

Ativos que ao falhar possuem capacidade de paralisar totalmente uma unidade de produção completa (edifício, fábrica) são classificados como "A". Recebem classificação "B" os ativos que ao falhar paralisam somente um linha de produção ou parte de uma unidade de produção. A classificação "C" é dada a ativos que ao falhar não causam paralisações significativas.

\section{CF - Confiabilidade:}

Este critério é relativo à frequência de falhas de um ativo não adequadamente mantido. Ativos com tempos entre falhas menor que cinco horas recebe classificação " $A$ ". Tempos entre falhas de cinco a dez horas determinam os ativos com classificação "B". Ativos com classificação " $C$ " são aqueles que possuem tempos entre falhas maiores que dez horas. Outra forma de classificação é considerar os tempos entre falhas provocados por $20 \%$ dos ativos como categoria "A". Dessa forma, os tempos entre falhas provocados por $30 \%$ dos itens devem ser classificados como "B" e os restantes 50\% como "C".

\section{MT - Mantenabilidade:}

Último critério a ser avaliado, é relativo ao tempo médio de reparo de uma falha num ativo. itens com tempo médio de reparo acima de noventa minutos são classificados como "A". Entre quarenta e cinco e noventa minutos, classificação "B", e, abaixo de quarenta e cinco minutos, classificação "C". 
A condução regular de manutenção preventiva baseada em condição apresenta resultados bastante diferenciados se comparados em relação à manutenção preventiva periódica. Na MP-BC, além das vantagens citadas para 0 caso da manutenção preventiva periódica e do incremento das mesmas conforme indicado na tabela 3.5, ocorrem os seguintes benefícios principais (SULLIVAN et al., 2010; IAEA, 2007; CHIMACK; AARDSMA; NOVOSEL, 2006):

- 8 a $12 \%$ de redução de custos em relação à manutenção preventiva periódica;

- 30 a $40 \%$ de redução de custos em relação à manutenção corretiva;

- 35 a $45 \%$ de redução nos tempos de parada para manutenção;

- Eliminação de 70 a $75 \%$ das paradas não programadas;

- 20 a $25 \%$ de incremento na capacidade de produção.

Tabela 3.5 - Aspectos positivos e negativos da Manutenção Preventiva Baseada em Condição

\begin{tabular}{ll}
\hline \multicolumn{1}{c}{ Aspectos Positivos } & \multicolumn{1}{c}{ Aspectos Negativos } \\
\hline - Elimina a maioria dos aspectos negativos & - Necessidade de bom treinamento e \\
das manutenções corretiva e preventiva. & certificação para o pessoal técnico. \\
- Total integração com o planejamento dos & - Difícil aplicação a ativos com \\
recursos. Reforça as ações & características pouco conhecidas. \\
preventivas/constante avaliação dos riscos. & - A variabilidade de carga/produção e \\
- Somente são realizados os reparos & velocidade na operação dos ativos leva \\
- necessários. & a riscos de detecção do defeito em \\
- Reduz as interrupções de funcionamento. & tempo suficiente para evitar a falha. \\
- Reduz o risco de falhas catastróficas. & Risco na determinação dos intervalos de \\
- Previne e diminui a taxa de falhas. & inspeção para acompanhamento da \\
- Aumenta a vida útil do ativo e diminui seu & evolução de um defeito após sua \\
- custo de ciclo de vida. & detecção. \\
- Aumenta a capacidade de programação de & - Oferece riscos na determinação dos \\
serviços permitindo melhor aproveitamento & parâmetros de alerta, alarme e máximos \\
- de recursos e pessoal. & admissíveis antes da falha. \\
- Delhora o desempenho/eficiência. & Exige muito planejamento de serviços e \\
- Aumenta a disponibilidade e a & administração de materiais. \\
- Aumenta a produtividade. & \\
- Melhora a qualidade dos produtos. & \\
- Reduz os custos com mão de obra e peças. & \\
\hline
\end{tabular}

Fonte: CHIMACK; AARDSMA; NOVOSEL, 2006; SULLIVAN et al., 2010; NASA, 2008, adaptadas 
Feit apud Chimack, Aardsma e Novosel (2006) relata um estudo de caso numa empresa fabricante de plásticos, onde, em quinze anos de implantação de MP-BC, a eficiência operacional da fábrica cresceu de 85 para $99 \%$, permitindo dobrar a capacidade de produção praticamente sem investimentos. Além disso, o programa de análise de vibração aumentou a produtividade e diminuiu a frequência de reparos não programados de 33\% para valores entre 3 a $4 \%$.

Todos esses benefícios são resultado da capacidade da MP-BC em detectar e antever a falha. Essa situação proporciona uma condição de planejamento dos serviços, preparação de material/peças e mão de obra bastante apuradas, e somente intervir no equipamento no momento mais oportuno. Essa característica de gestão produz benefícios em cascata que levam a uma melhora substancial no desempenho das instalações como um todo.

\subsubsection{Manutenção Centrada em Confiabilidade (MCC)}

A manutenção centrada em confiabilidade, MCC, ou, Reliability-Centered Maintenance, RCM, basicamente combina várias estratégias de manutenção com técnicas e ferramentas da engenharia da confiabilidade e qualidade, em uma abordagem de gerenciamento de riscos sistemáticos, como base para as decisões de gerenciamento eficaz de manutenção (BACKLUND; AKERSTEN, 2003).

Vários autores comentam sobre a MCC. Conforme Nowlan e Heap apud Backlund (2003, p. 32), "o principal objetivo da MCC é preservar a função e o desempenho de um ativo e não o ativo propriamente dito". Moubray (1997, p. 22) define a MCC como "...o processo utilizado para determinar o que deve ser feito para assegurar que um determinado ativo continue a realizar o que seus usuários querem que execute no contexto operacional definido". Conforme IEC 60300-3-11 apud Backlund (2003, p. 32), a MCC "pode ser descrita como sendo uma abordagem sistemática para identificar efetivas e eficientes tarefas de manutenção para um ativo em acordo com um conjunto específico de procedimentos".

De maneira geral, os objetivos principais da MCC são determinar quais são os ativos críticos numa instalação, suas funções, seus modos de falha e quais as melhores estratégias de manutenção a serem aplicadas nesses itens. De forma 
lógica, bastante disciplinada, sua metodologia é usada para se conseguir um efetivo meio de priorização de atividades de maneira a melhorar a capacidade de mitigar a quebra de um item e suas consequências para a qualidade dos produtos e serviços (BACKLUND; AKERSTEN, 2003).

Basicamente a metodologia utilizada na MCC procura (BERTLING, 2005):

- Preservar a função do ativo;

- Identificar os modos de falha;

- Priorizar as necessidades das funções, e;

- Selecionar atividades de manutenção aplicáveis e efetivas.

A literatura existente relaciona diferentes maneiras de formulação do processo de criação de $\mathrm{MCC}$ e de se obter um programa consistente de manutenção (BERTLING, 2005). Um dos mais usados atualmente foi apresentado por Moubray (1997). Esse autor menciona que para analisar os aspectos de manutenção de um sistema e seus componentes, o primeiro passo é identificar os ativos e determinar quais deles devem ser avaliados. Posteriormente o processo de MCC pode ser desenvolvido por meio de sete questões básicas para os ativos selecionados (MOUBRAY, 1997):

- Quais são as funções e os padrões de desempenhos requeridos para o ativo no contexto operacional atual?

- De que maneiras o ativo falha ao cumprir sua função?

- Quais são as causas de cada falha funcional?

- Quais são os efeitos de cada falha?

- Quais são as consequências de cada falha?

- Como cada falha pode ser prevenida?

- Como proceder se nenhuma atividade de prevenção é possível?

As respostas a essas questões podem ser obtidas através da sequência de sete passos descrita a seguir (DESHPANDE; MODAK, 2002; MÁRQUEZ et al., 2009; RAUSAND, 1998; HELMAN; ANDERY, 1995): 


\section{Passo 1 - Seleção do ativo e coleta de dados}

Deve levar em conta o valor do ativo, os custos de manutenção (mão de obra, peças, etc), de perdas (de produção, faturamento, lucro cessante) e consequências colaterais da falha (riscos à segurança, ao meio ambiente). Informações técnicas, diagramas, dados históricos, manuais de operação e manutenção são essenciais para condução dos trabalhos de análise. Montagem da equipe de especialistas para condução da análise MCC.

\section{Passo 2 - Definição dos limites do ativo}

Deve indicar a abrangência e limitações da análise. Onde começa e termina o item sob investigação.

\section{Passo 3 - Descrição do ativo}

Características do contexto operacional do ativo, diagramas em blocos, fluxogramas, blocos funcionais. Levantamento das entradas e saídas do processo onde o item se insere. Definição do propósito e do desempenho do ativo.

\section{Passo 4 - Descrição das funções}

Com as informações obtidas dos passos de 1 a 3 é possível definir 0 propósito e desempenho do ativo. Ao fazer isso as funções estarão estabelecidas.

\section{Passo 5 - Modos e efeitos da falha - FMEA}

A partir desse passo a MCC utiliza o método Análise do Modo e Efeitos de Falhas ou como é mais conhecido, FMEA - Failure Mode and Effect Analisys. O FMEA é um método analítico bastante padronizado para detectar e eliminar falhas potenciais de maneira sistemática e completa. Para cada uma das funções encontradas (passo 4) são relacionados um ou mais modos de falha. Para cada modo de falha são investigados os efeitos, as consequência negativas, que podem acontecer nas saídas do processo. Uma vez relacionados os efeitos, são determinadas cada uma de suas causas, ou seja, as variáveis do processo que podem levar ao modo de falha e não cumprimento da função do ativo.

Nessa etapa também podem ser avaliadas as estratégias de manutenção cabíveis por meio da Árvore Lógica de Decisão (LTA - Logic Tree Analysis) mostrada na figura 3.3. A partir da caixa em seu topo, para cada modo de falha são 
feitas, sequencialmente, perguntas auto-explicativas, que conduzem à estratégia mais recomendada em casa situação (NASA, 2008).

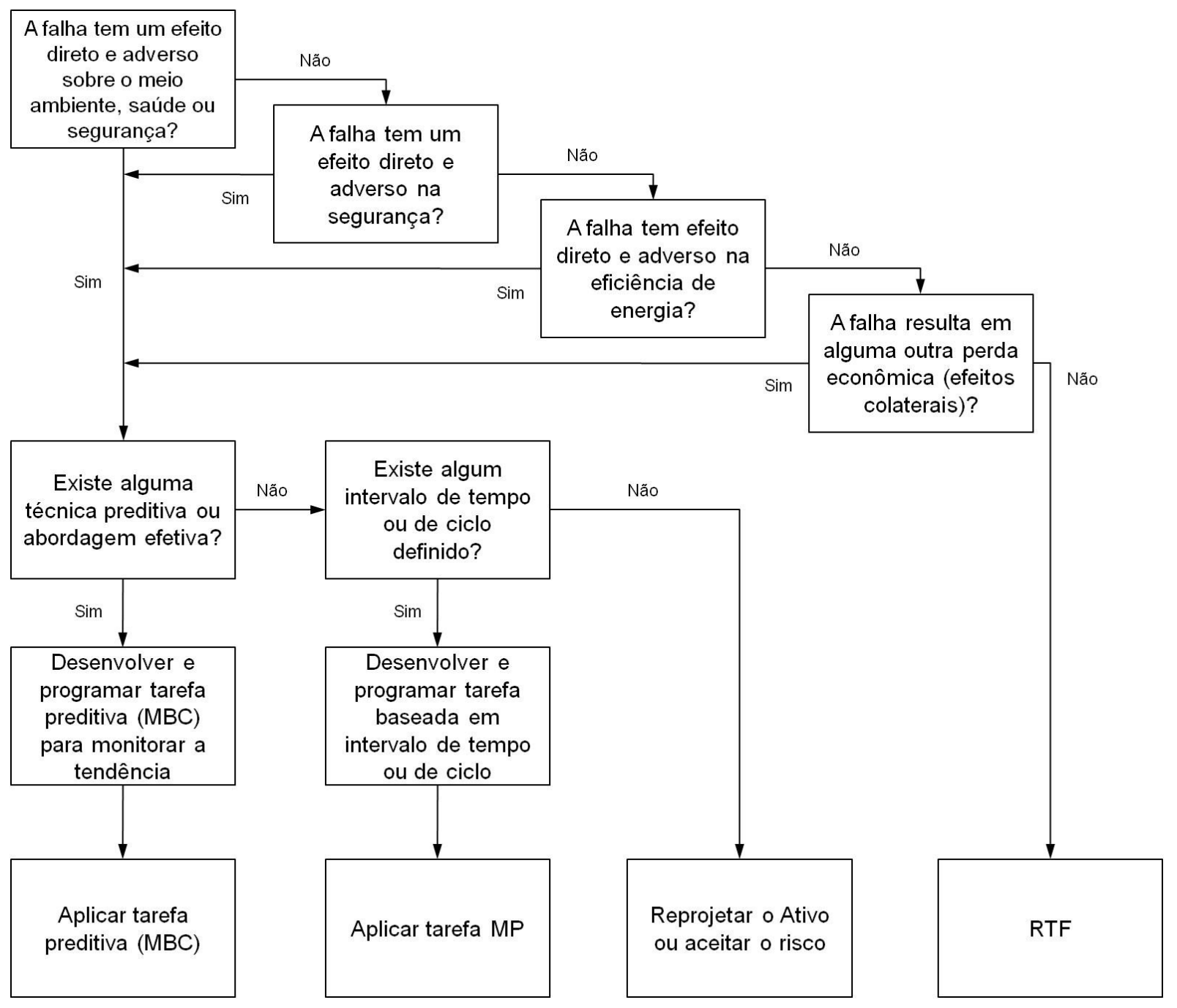

Figura 3.3 - Árvore lógica de análise para escolha de estratégias de manutenção Fonte: NASA, 2008, adaptada

\section{Passo 6 - Definição dos índices de Ocorrência, Gravidade, Detecção e de Prioridade de Risco - FMEA}

Definidas as possíveis causas, para cada uma delas são estipulados:

- Índice de Ocorrência, ou de probabilidade da mesma acontecer;

- Índice de Gravidade, que indica a severidade sobre o efeito da falha;

- Índice de Detecção, que é a probabilidade de detecção da causa da falha em sua fase inicial ou de defeito (ou de falha potencial);

- NPR, Número de Prioridade de Risco, que é o produto dos três índices mencionados. Quanto maior esse número, maior prioridade deve ser dada a ações de mitigação da causa. 


\section{Passo 7 - Seleção das atividades de manutenção - FMEA}

Seguindo da mais alta prioridade para a mais baixa, para cada uma das causas é determinado:

- O tipo de manutenção mais adequada, corretiva, preventiva ou baseada em condição, caso não tenha sido feita no passo 5;

- A descrição da atividade de manutenção a ser realizada e sua frequência;

- A justificativa das ações tomadas, se necessário.

A finalização do passo 7 também encerra a análise MCC sobre um ativo, que a seguir passa para o estágio de implantação do programa de manutenção escolhido.

A MCC representa atualmente o mais alto estágio de formulação de estratégias e ações para manutenção de ativos. Seu processo exige a formação de uma equipe multidisciplinar e multihierárquica com muito conhecimento sobre $\mathrm{o}$ ativo em análise, bem como de materiais e tecnologia. A necessidade de dados, tais como, projetos, manuais, orientações técnicas, composição dos ativos, levam à grande compilação de documentação técnica. A determinação das funções, efeitos das falhas e suas causas requerem constante análise por meio de diagramas de causa e efeito, análise de árvore de falhas (FTA - Failure Tree Analysis), entre outras ferramentas da qualidade. A determinação dos índices de Ocorrência, Gravidade e Detecção necessita, além do conhecimento do contexto operacional onde o ativo se encontra, de fundamentada análise dos dados históricos das falhas, suas consequências, frequências, inclusive com tratamento estatístico e probabilístico dos dados. Determinar o tipo de estratégia de manutenção a ser empregada e a atividade a ser realizada, também são ações que dependem de conhecimento do estado da arte de tecnologias, métodos e processos de gestão de manutenção.

A implantação da MCC leva a resultados superiores em termos da qualidade de serviços de manutenção, porém seu processo implica em grande aplicação de mão de obra especializada e dispêndio de tempo, o que restringe sua aplicação praticamente somente a ativos muito importantes para o processo, segurança e meio ambiente. No caso de sistemas de ar condicionado de grande porte, como o de água gelada, a MCC pode ser aplicada às máquinas chillers e sistema de alimentação em média tensão com excelentes resultados. 
A tabela 3.6 apresenta e relaciona os principais aspectos desse tipo de abordagem de manutenção.

Tabela 3.6 - Aspectos positivos e negativos principais da Manutenção Centrada em Confiabilidade

\begin{tabular}{ll}
\hline \multicolumn{1}{c}{ Aspectos Positivos } & \multicolumn{1}{c}{ Aspectos Negativos } \\
\hline - Proporciona o melhor e mais eficiente & - Longo tempo de implantação \\
programa de manutenção & - Quantidade e qualidade das informações \\
- Minimiza a frequência de revisões dos & do ativo \\
ativos & - Tratamento dos dados \\
- Reduz a probabilidade de falhas súbitas & - Volume de detalhamento necessário \\
- Foco em ativos críticos & - Exigência de equipe de implantação e \\
& condução do programa altamente \\
& especializada \\
& Dificuldade de definição dos índices de \\
& Ocorrência, Gravidade e Deteç̧ão \\
& coerentes \\
\hline
\end{tabular}

Fonte: CHIMACK; AARSDMA; NOVOSEL, 2006; SULLIVAN et al., 2010; NASA, 2008, adaptadas

Bertling (2005) comenta que a MCC fornece um método para tratar a complexidade das questões de manutenção de ativos, mas nada acrescenta de novo sob o ponto de vista estritamente técnico. Finalmente, Backlund (2003, p. 32) comenta que,

\begin{abstract}
Basicamente, a MCC não contém quaisquer novos princípios para operações de manutenção, é mais uma forma estruturada de utilizar o melhor de vários métodos e disciplinas, ver por ex. Sandtorv e Rausand (1991) e Sutton (1995). A MCC pode, em muitos aspectos, ser comparada com algum tipo de garantia de qualidade de desempenho de manutenção, definida como: "toda ação sistemática necessária para planejar e verificar que os esforços gastos na manutenção preventiva são aplicáveis e rentáveis (SANDTORV e RAUSAND, 1991)".
\end{abstract}

\title{
3.3. Estratégias e Estrutura de manutenção
}

De acordo com os textos anteriores percebe-se que cada uma das estratégias de manutenção possui suas características e particularidades positivas e negativas. A figura 3.4 apresenta de modo resumido essa situação, onde notamos a MCC na mais alta posição da escala. 


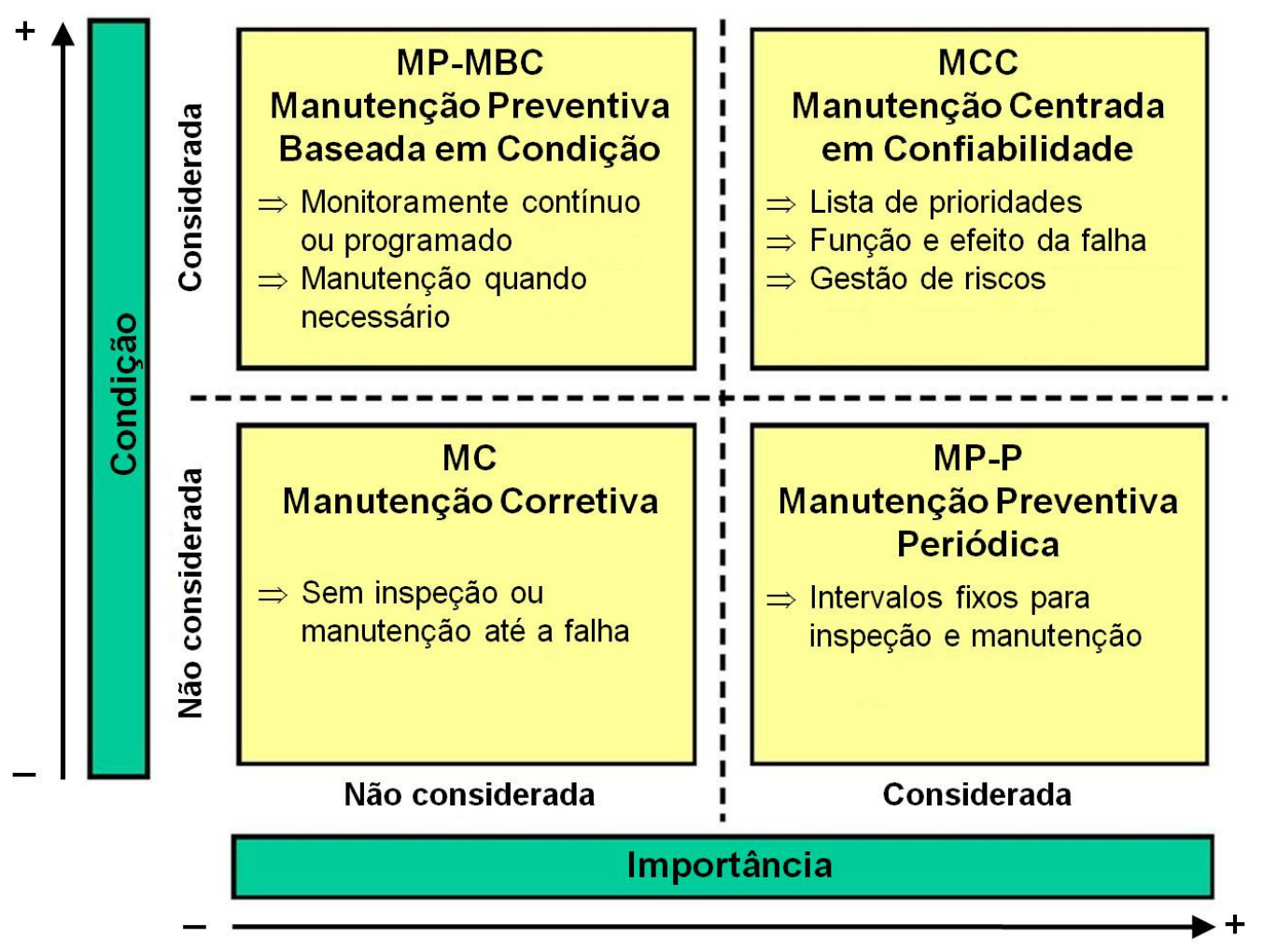

Figura 3.4 - Classificação de estratégias de manutenção Fonte: SCHNEIDER et al., 2006, adaptada

A figura 3.4 evidencia que a estratégia mais eficiente é a MCC, que combina 0 que há de melhor da MC, MP-P e MP-BC. O que leva à conclusão de que não há estratégias essencialmente inadequadas, mas sim estratégias mais adequadas em determinadas situações e circunstâncias. Ponderar a participação de cada uma delas num plano global de manutenção de maneira eficaz não é tarefa simples. Utilizar o método MCC para todos os ativos, além de demorado, pode não ter uma boa relação custo-benefício. A MCC só deve ser aplicada em ativos de custo muito alto ou cuja falha provoca consequências desastrosas. A MP-BC além de ser de mais simples implantação, mostra ser uma estratégia de moderado custo e com resultados excelentes a médio e longo prazo, que além de fazer parte de um plano de MCC, pode ser implantada de modo independente.

Nos tópicos anteriores se discorreu sobre as estratégias de manutenção corretiva, preventiva e centrada em confiabilidade. Enquanto na manutenção corretiva a estratégia é aguardar a falha do ativo e reparar posteriormente, na manutenção preventiva periódica busca-se estudar os ciclos de tempo ou de produção até falha de modo a tomar ações de correção antes que a mesma aconteça. Na MP-BC através da inspeção regular por meio de técnicas preditivas, 
procura-se definir o melhor momento para intervir no ativo e eliminar o defeito antes da falha. No caso da MCC, se trata de analisar a função de cada item e seus respectivos modos de falha, detalhadamente, levando-se em conta critérios de risco e consequências das falhas, de forma a preservar a função do ativo e agir no melhor momento por meio de ações de manutenção. Considerando esses conceitos e os comentários finais de Backlund (2003), nessa dissertação adota-se a estrutura de estratégias de manutenção proposta pelo IAEA (2007) na figura 3.5.

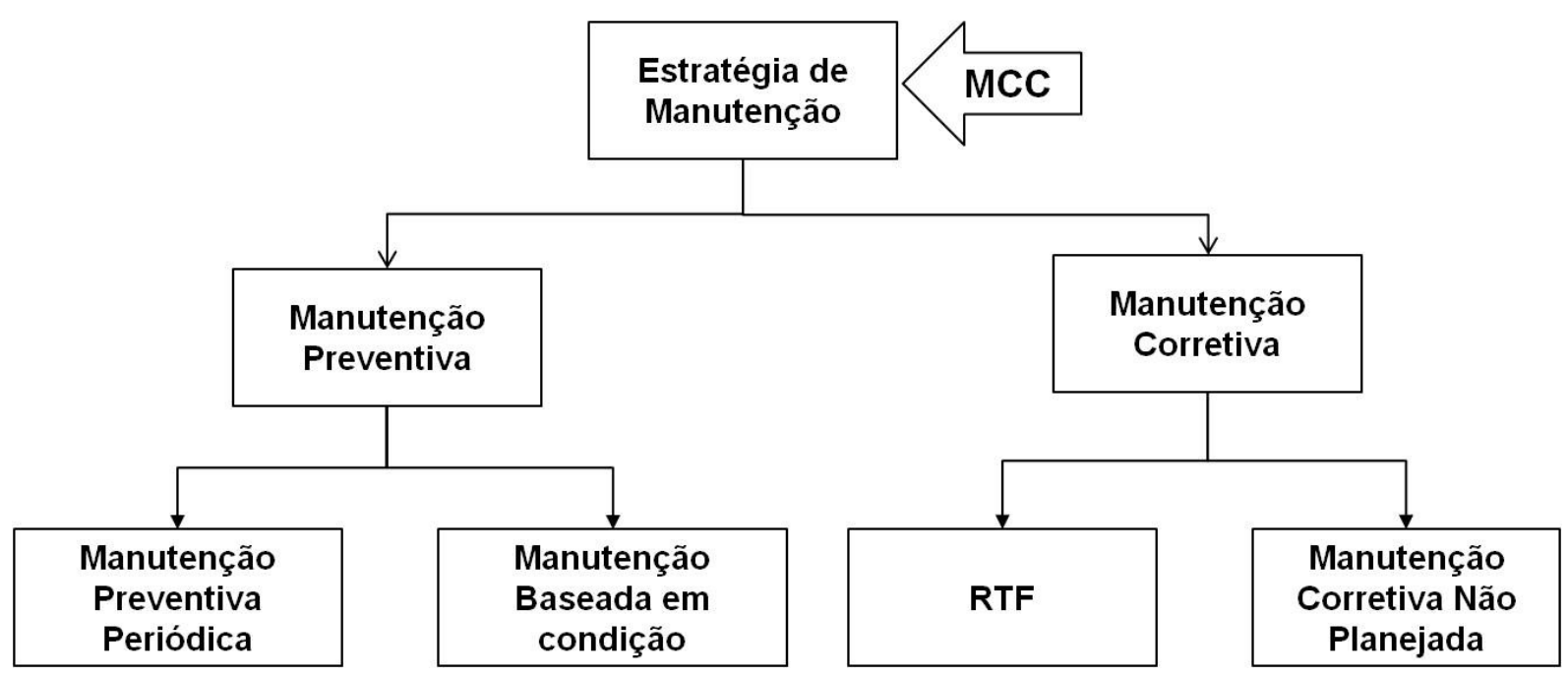

Figura 3.5 - Estratégias de manutenção - Estrutura Fonte: IAEA, 2007, adaptada

Na filosofia MCC, a manutenção corretiva não planejada, preventiva periódica e baseada em condição são empregadas de modo integrado, numa composição de tarefas otimizadas (AFEFY, 2010). Nessa figura nota-se que a MCC aparece em seu topo e com o sentido de orientar, assessorar as estratégias de manutenção preventiva e corretiva, estrutura essa mais apropriada com os conceitos apresentados neste capítulo.

\subsection{A manutenção preventiva baseada em condição e os requisitos de sustentabilidade para um edifício de escritórios}

Da exposição de cada uma das estratégias de manutenção, nota-se que aquela que atende a todas as dimensões da sustentabilidade, ou seja, crescimento 
econômico, proteção ao meio ambiente e progresso social é a estratégia de manutenção preventiva baseada em condição.

Com sua filosofia de somente intervir nos ativos uma vez constatada uma anomalia que pode levar o mesmo à falha, possui aspectos positivos que superam em muito seus aspectos negativos, bem como as qualidades da manutenção corretiva e preventiva periódica com relativa superioridade. Sua adoção, como já mencionado, gera efeitos em cascata que laboram para maior confiabilidade e melhor desempenho, além da extensão da vida ou durabilidade do ativo. Essa durabilidade e o menor consumo de peças e materiais, leva à otimização do custo de ciclo de vida, o que acaba provocando uma diminuição da carga sobre o planeta, bem como a redução de emissões para a atmosfera. Melhor confiabilidade e desempenho levam à maior disponibilidade do item, tendo como consequência maior benefício ao usuário ou ocupante da edificação. No caso do exemplo adotado nessa dissertação, um sistema de ar condicionado, os benefícios aos ocupantes podem ser traduzidos em melhor qualidade do ar e conforto térmico, quesitos esses importantes para a satisfação, saúde, bem-estar e maior produtividade no trabalho. Todo esse cenário tende a levar a maiores lucros, no médio ou longo prazo, tanto para aquele que usa o imóvel para suas atividades econômicas, quanto para aquele que tem no imóvel sua fonte de renda, o que atende de forma adequada e balanceada todas as dimensões da sustentabilidade para um edifício de escritórios. 


\section{APLICAÇÃO DE MANUTENÇÃO BASEADA EM CONDIÇÃO NUM SISTEMA DE AR CONDICIONADO PREDIAL}

Visto os conceitos que envolvem a sustentabilidade dos edifícios e os diversos tipos de gestão de ativos, neste capítulo pretende-se apresentar técnicas de manutenção baseada em condição que podem ser aplicadas nos principais equipamentos e componentes de um sistema de ar condicionado predial, incluindo sua alimentação de energia elétrica. Manutenção adequada, índices altos de disponibilidade, confiabilidade e segurança são importantes tópicos que esse sistema deve alcançar para proporcionar conforto térmico no interior das edificações destinadas ao trabalho. Saúde, bem-estar e satisfação com o ambiente interno são importantes requisitos para desempenho das tarefas de modo eficiente, com alta produtividade e desempenho de seus ocupantes.

\subsection{O sistema de ar condicionado de expansão indireta e condensação a água}

Dentre os vários sistemas de condicionamento de ar existentes, o tipo de expansão indireta com condensação a água se caracteriza pela quantidade de componentes, de ser normalmente empregado em instalações de médio para grande porte, automação e consumo de energia.

Nesse tipo de sistema, água é empregada para transportar o calor rejeitado desde o ambiente interno até o ambiente externo (atmosfera). Desse modo, toda a água gelada produzida na unidade resfriadora de líquido (chiller) é bombeada pelas bombas primárias e distribuída ao prédio por meio de rede de tubulações denominada Anel Primário. No edifício onde se deseja o condicionamento de ar existe o chamado Anel Secundário, que circula água gelada para todos os seus condicionadores de ar (fan-coils) dos ambientes daquele edifício. O diagrama de rede desse sistema é mostrado sucintamente na figura 4.1.

O circuito primário é formado por chiller a compressão de vapor, bombas primárias de água gelada (BAG) e de água de condensação (BAC), torre de 
resfriamento, tanque de expansão, compressores de ar e respectiva instrumentação de supervisão e controle. Todos esses equipamentos são implementados numa Central de Água Gelada (CAG). O Anel Primário de distribuição de água gelada (tubulação de alimentação e de retorno) liga a CAG à casa de bombas do Anel Secundário do edifício.

(FC) FAN-COIL

ANEL SECUNDÁRIO

(8AG) BOMBA DE ÁGUA GELADA

PRÉDIO

(BAC) Bomba dE ÁGUA dE CONDENSAÇÃo

COMPRESSOR DE AR

S compressor de Gás

VÁLVULA DE EXPANSĀo

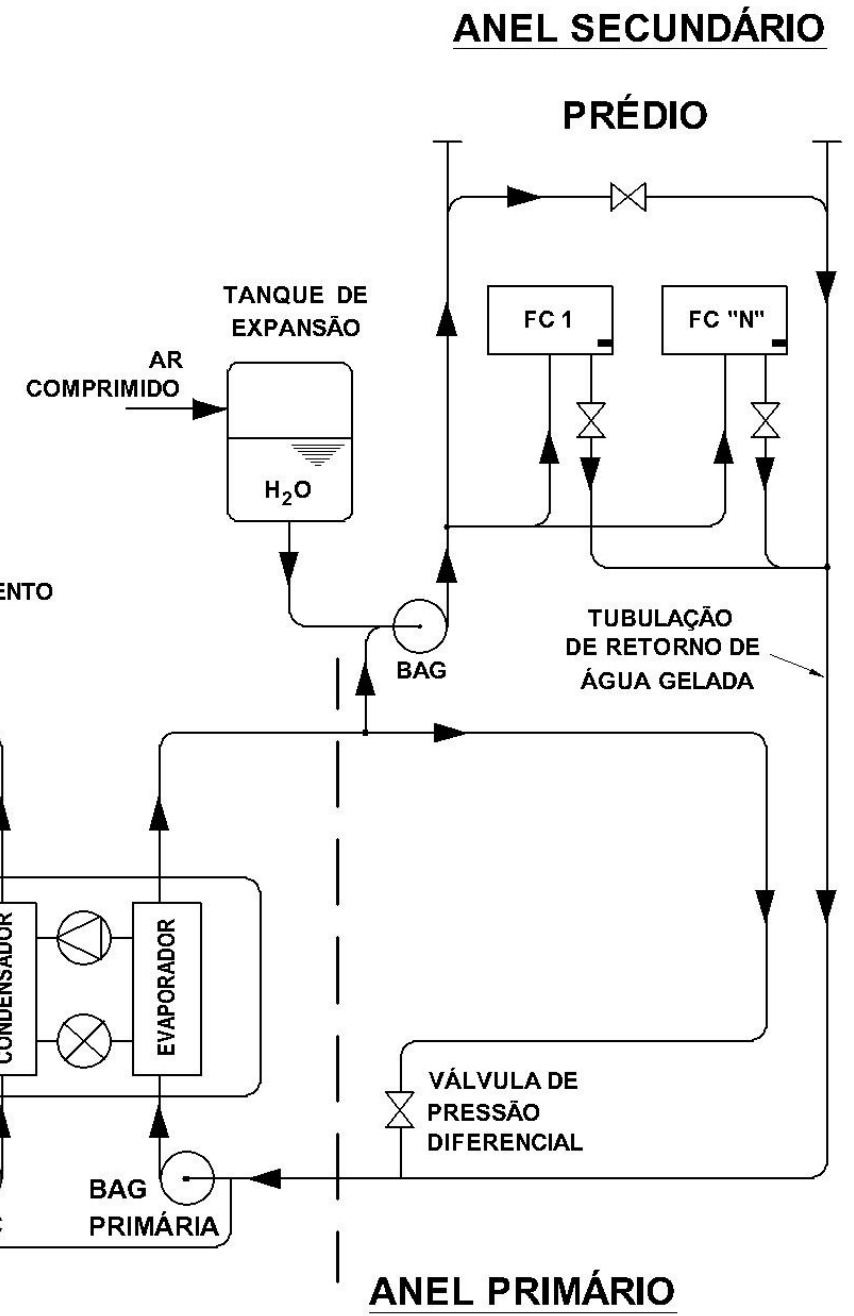

CAG

ANEL PRIMÁRIO

Figura 4.1 - Sistema de ar condicionado de expansão indireta e condensação a água - Circuito primário e secundário de distribuição de água gelada

O Anel Secundário do edifício é formado por tanques de expansão, bombas de água gelada acionadas por painéis elétricos e suas tubulações, que a partir do Anel Primário bombeiam essa água para as entradas dos fan-coils, cujas saídas estão conectadas à tubulação de retorno de água gelada do prédio e esta à tubulação de retorno do Anel Primário. 


\subsection{Manutenção Baseada em Condição - Técnicas de inspeção preditiva aplicadas a um sistema de ar condicionado de expansão indireta e condensação a água}

Visto a diversidade de seus componentes e suas diferentes funções, o sistema de ar condicionado de expansão indireta e condensação a água talvez seja o que oferece maiores condições de emprego de Manutenção Baseada em Condição e suas técnicas de monitoramento preditivas, onde seus resultados podem ser mais visíveis e também avaliados em termos de custo-benefício num edifício. As informações obtidas da aplicação dos variados métodos preditivos podem ser analisadas de modo a checar a condição/degradação dos diversos equipamentos em relação a parâmetros de comparação requeridos, de modo a determinar o melhor momento para sua manutenção (NASA 2004, 2008).

Basicamente um sistema desse tipo pode ser sub-dividido em três partes:

- As partes mecânicas de bombas, motores, tubulações, máquinas centrífugas resfriadoras de líquidos (chiller's), vasos de pressão, etc;

- Os componentes elétricos de bombas, motores, chiller's, dispositivos de proteção e seccionamento elétrico, tais como, disjuntores, chaves, fusíveis, cabos de energia, transformadores de força, etc, e;

- Os sistemas de supervisão e controle, mais comumente chamados de sistemas de automação, composto de sensores, medidores, controladores, computadores e programas de supervisão ${ }^{1}$.

Uma grande parte de investimentos num edifício é devido aos equipamentos mecânicos e elétricos que compõem os sistemas de ar condicionado. O funcionamento adequado desses sistemas, dentro da faixa de valores admissíveis, é essencial para assegurar desempenho adequado tanto do sistema de ar condicionado, quanto do prédio, além de oferecer condições de segurança para as pessoas e instalações.

Manutenção baseada em condição aplicada a sistemas elétricos e mecânicos abrange várias tecnologias e técnicas preditivas que proporcionam informações

\footnotetext{
${ }^{1}$ Sistemas não abordados nessa dissertação.
} 
importantes e contribuem sobremaneira para prevenção de falhas e extensão da vida útil dos componentes. O monitoramento de parâmetros-chave proporciona condições adequadas para detecção e correção de defeitos incipientes.

As técnicas de monitoramento de equipamentos mecânicos e elétricos sob um programa de manutenção baseada em condição devem levar em conta também a necessidade de desligar ou não os sistemas, isto é, colocar fora de serviço ou não os equipamentos para que os testes e inspeções possam ser realizados. Num sistema de ar condicionado os métodos preditivos mais empregados e a condição de realização são:

\section{a) Técnicas de monitoramento com os equipamentos em serviço}

- Análise de Vibração

- Análise por Ultrasom

- Análise Termográfica ou por Infravermelho

- Análise de Assinatura de Corrente de Motores ou MCSA (Motor Current Signature Analysis)

- Análise de Assinatura Elétrica ou ESA (Electrical Signature Analysis)

- Análise de Óleo Isolante de Transformadores de Potência

- Relação de Transformação de Transformadores ou TTR (Transformer Turn Ratio)

- Ensaios Não Destrutivos (END)

b) Técnicas de monitoramento com os equipamentos fora de serviço

- Análise de Óleo Lubrificante

- Resistência Ôhmica de Enrolamentos

- Resistência Ôhmica de Contato

- Resistência Ôhmica de Isolamento

- Fator de Potência da Isolação

- Fator de Potência da Isolação e Fator de Dissipação

- Análise de Circuito de Motor ou MCA (Motor Circuit Analysis) 


\subsubsection{Análise de Vibração}

Aplicada principalmente em máquinas rotativas e estruturas industriais, a análise de vibração é uma das técnicas de grande resultado efetivo em manutenção baseada em condição. Seu princípio de funcionamento se baseia na medição da oscilação de um corpo em torno de sua posição de equilíbrio.

Qualquer máquina é formada por diversos componentes articulados, que uma vez em movimento, devido às tolerâncias de montagem e ajustes de acoplamento, ficam sujeitos a uma oscilação característica. Essas vibrações se transmitem a todo o conjunto da máquina, terminando por produzir um espectro de frequências próprio daquele sistema, sua assim chamada "assinatura". A análise dessa "assinatura" possibilita verificar se o equipamento está em condições normais de funcionamento ou com algum defeito incipiente que pode levar a uma falha. Em caso de defeito, pode-se identificar o componente envolvido e seu estado de degradação, determinando-se a gravidade da deficiência detectada. Segundo Marçal (2000, p.31),

\footnotetext{
Cada vez que uma peça altera suas características mecânicas por desgaste ou trinca, uma componente de frequência do sistema será alterada. Havendo alteração no acoplamento entre as peças altera o coeficiente de transmissão do sinal entre as peças e, em consequência, a forma de frequência global do sistema. Folgas, defeitos ou desalinhamentos de rolamentos ou mancais de máquinas rotativas refletem-se na alteração de frequências ou surgimento de novas frequências.
}

De excelente resultado para a gestão de ativos, esta técnica aplicada em equipamentos rotativos, tais como, motores, bombas, turbinas, compressores, motores, redutores, agitadores, ventiladores, sopradores e eixos, entre outros, possui probabilidade de detecção de defeitos de $92 \%$ e de alarme falso de $8 \%$ (NASA, 2008).

Por meio de equipamentos, softwares, sensores e filtros especialmente desenvolvidos, além da necessária experiência e conhecimento do pessoal técnico envolvido, a análise de vibração se baseia na medição de três grandezas, ou seja: Deslocamento, que é a amplitude máxima do sinal de vibração ou o afastamento de sua posição de equilíbrio; Velocidade, indica quão rápido o sinal de vibração acontece, e; Aceleração, relacionada às forças que causam vibração. 
Adicionalmente, a frequência e o ângulo de fase do sinal de vibração são também medidos com o intuito de, respectivamente, identificar a causa da anomalia e o ponto onde a massa giratória fora do centro de rotação se encontra em relação ao sensor do equipamento de medição de vibração, importante quesito para correção de desbalanceamentos, desalinhamento, excentricidade, ressonância, etc (SILVA, 2006; IAEA, 2007).

A figura 4.2 mostra o campo de aplicação das medições de deslocamento, velocidade e aceleração em relação à frequência.

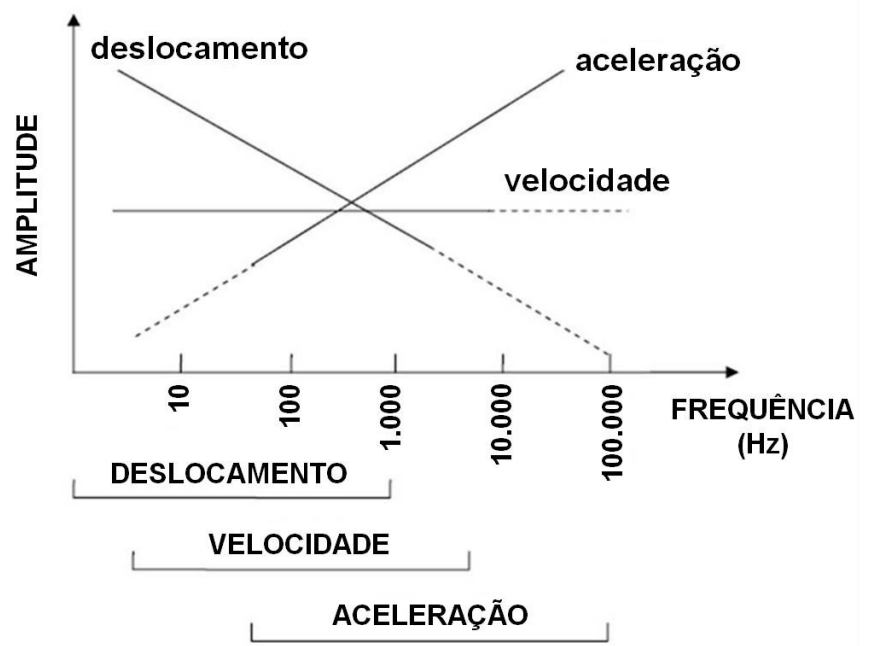

Figura 4.2 - Comparação das amplitudes das grandezas dinâmicas com a frequência Fonte: SILVA, 2006, adaptada

À medida que a velocidade de uma máquina aumenta, aumenta sua frequência e a amplitude de aceleração, enquanto a amplitude de deslocamento diminui. A velocidade é bastante estável na maior parte das frequências.

Abaixo de $1.000 \mathrm{~Hz}$ a técnica que se mostra mais apropriada é a de medição de amplitude de deslocamento. A partir de uma frequência de $1.000 \mathrm{~Hz}$ deve-se medir a vibração em termos de aceleração, uma vez que o deslocamento diminui fortemente com a frequência e o crescimento pronunciado do sinal de aceleração em altas frequências favorece sua utilização. Velocidade e aceleração vibratória são as medições mais adequadas a serem utilizadas para avaliação de máquinas de velocidades média e alta, enquanto o deslocamento vibratório é recomendado para grandes estruturas e máquinas de baixa rotação (MARÇAL, 2000).

Num sistema de ar condicionado a análise de vibrações pode ser empregada numa grande variedade de equipamentos, tais como, motores elétricos, compressores, ventiladores, redutores de velocidade, acionamentos de fan-coils por 
correias, bombas de água e até transformadores de potência. Dentre os principais defeitos que a técnica consegue detectar estão: defeitos em mancais de rolamentos e de deslizamento, desbalanceamento e desalinhamento, empenamento de eixos, excentricidade de rotor e estator, vibrações com origem no circuito magnético, má condição de fixação da máquina ("pé manco"), defeitos em engrenagens, cavitação, falta de alinhamento entre polias de acionamento. Em tubulações e transformadores de potência pode-se aplicar o método para avaliação de vibrações devido a defeitos em suportes e sistemas de fixação (de enrolamentos internos, por exemplo).

\subsubsection{Exemplos de aplicação}

a) Defeito em pista de rolamento de bomba de água gelada: A figura 4.3 mostra os dados de nível global obtidos do programa de monitoramento de vibração de rolamentos numa bomba de água gelada durante 31 meses. Nesse tipo de gráfico é costume indicar duas linhas de referência. A de atenção mostra que o valor medido se aproxima de valores máximos permissíveis. $O$ de alarme indica que o reparo deve ser feito com urgência. Nota-se na figura que apesar das medições indicarem valores razoavelmente estáveis, a última revela um aumento abrupto que ultrapassa em muito a linha de referência de alarme.

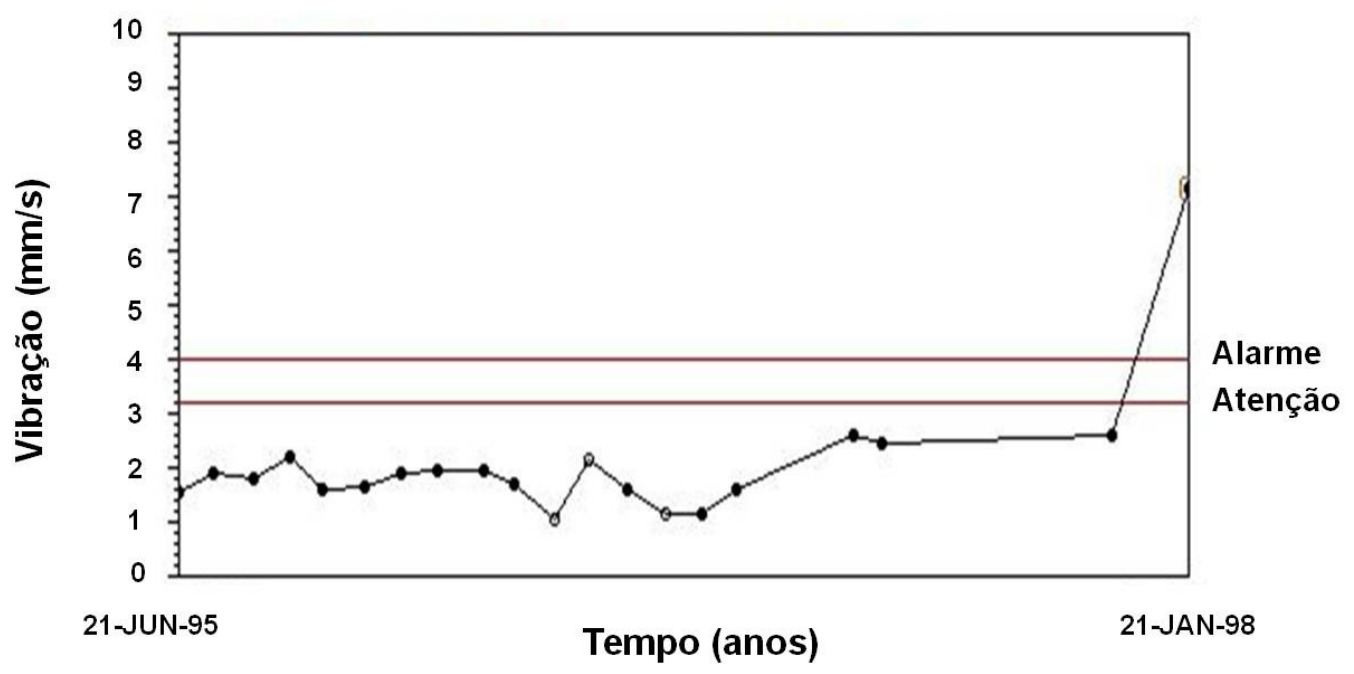

Figura 4.3 - Curva de tendência do valor global de vibração de rolamentos Fonte: STEVENS, 2011, adaptada 
Após a análise de vibração da bomba e obtido seu espectro mostrado na figura 4.4.(a), de acordo com Stevens (2011) se percebe uma freqüência de defeito calculada em 192,5 Hz, o que, no caso, indica uma anomalia na pista interna do rolamento.

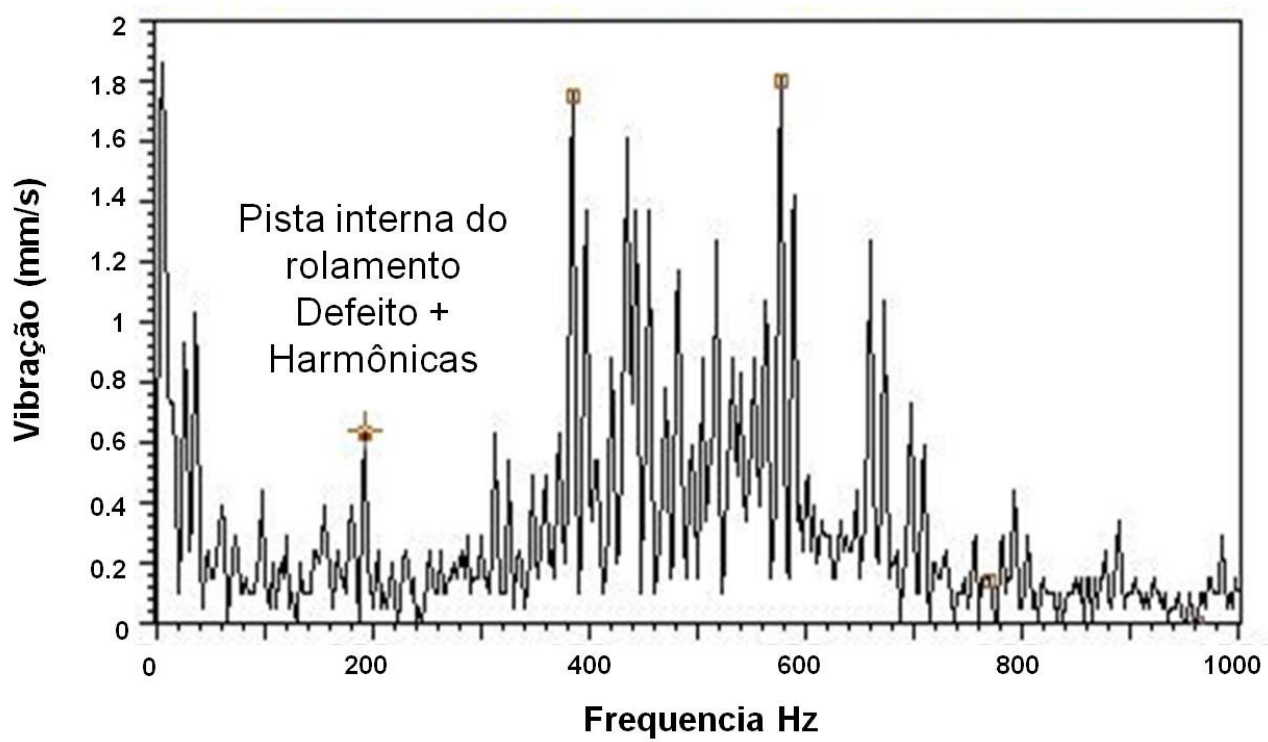

Figura 4.4 (a) - Espectro de vibração que indica defeito na pista interna de rolamento $(192,5 \mathrm{~Hz})$ Fonte: STEVENS, 2011, adaptada

A figura 4.4.(b) mostra o defeito na pista do rolamento (trinca no material).

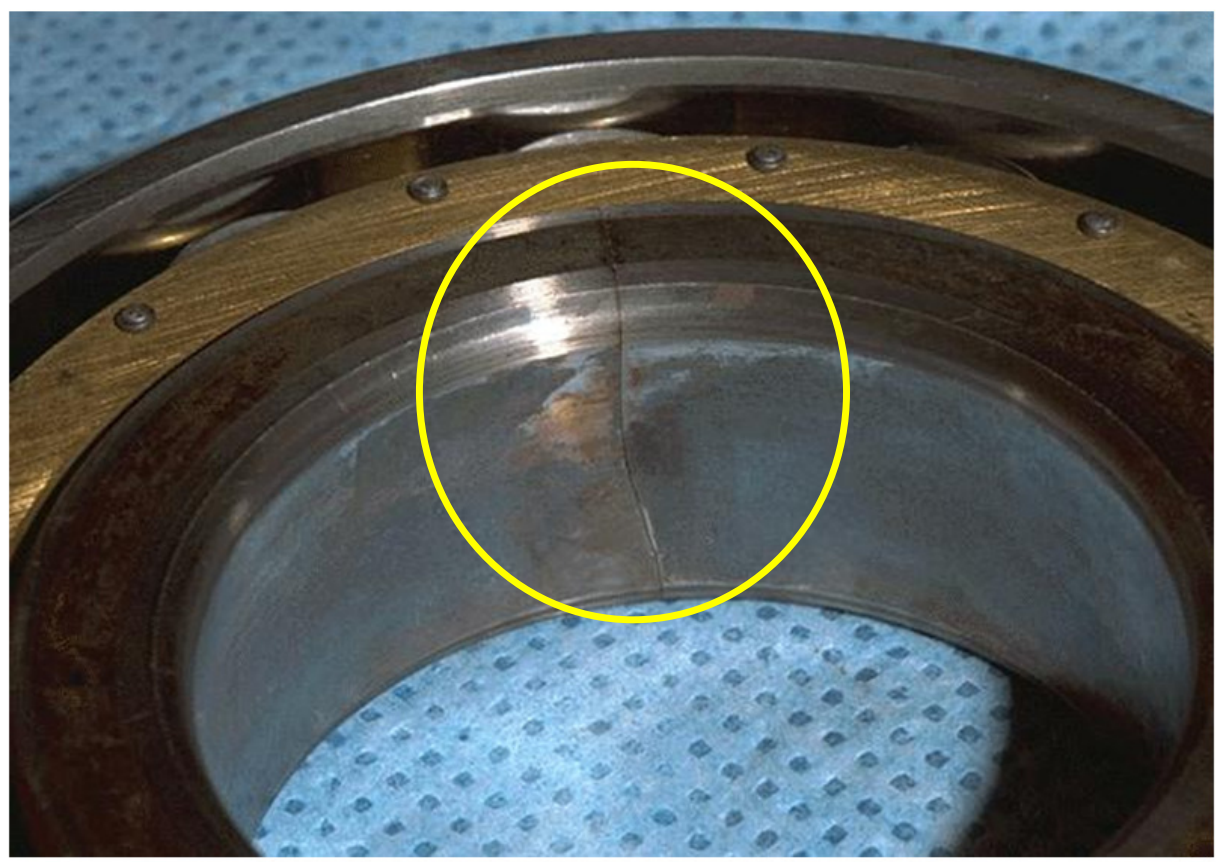

Figura 4.4 (b) - Defeito (trinca) encontrado em pista de rolamento Fonte: STEVENS, 2011 
b) Compressor centrífugo desbalanceado: $O$ gráfico de tendência da figura 4.5 mostra um aumento substancial no valor da vibração medida num compressor centrífugo que ultrapassa a linha de alarme (STEVENS, 2011).

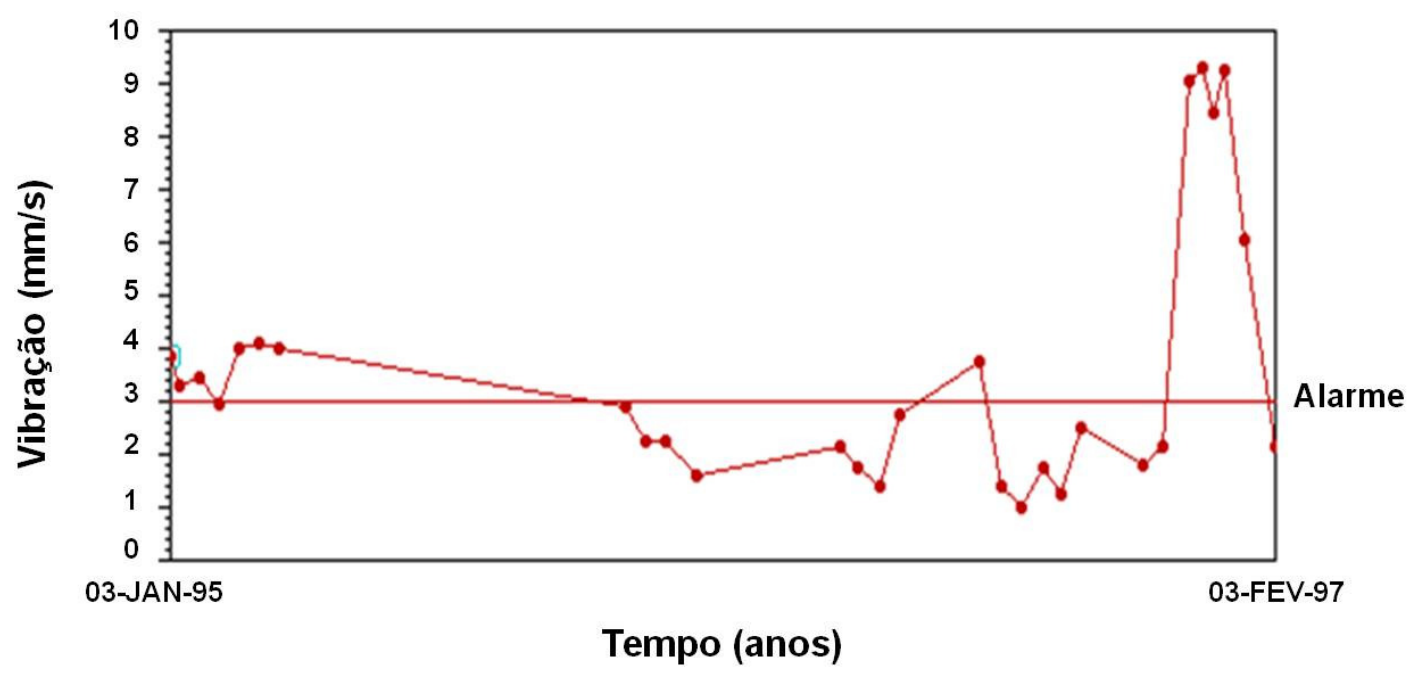

Figura 4.5 - Gráfico de tendência de amplitude global do compressor centrífugo Fonte: STEVENS, 2011, adaptada

$\mathrm{Na}$ figura 4.6.(a) temos o espectro de vibração que mostra um pico na frequencia de $1075 \mathrm{~Hz}$. Realizado o balanceamento, a figura 4.6.(b) mostra que a ação solucionou o defeito, trazendo a vibração a valores aceitáveis (STEVENS, 2011).

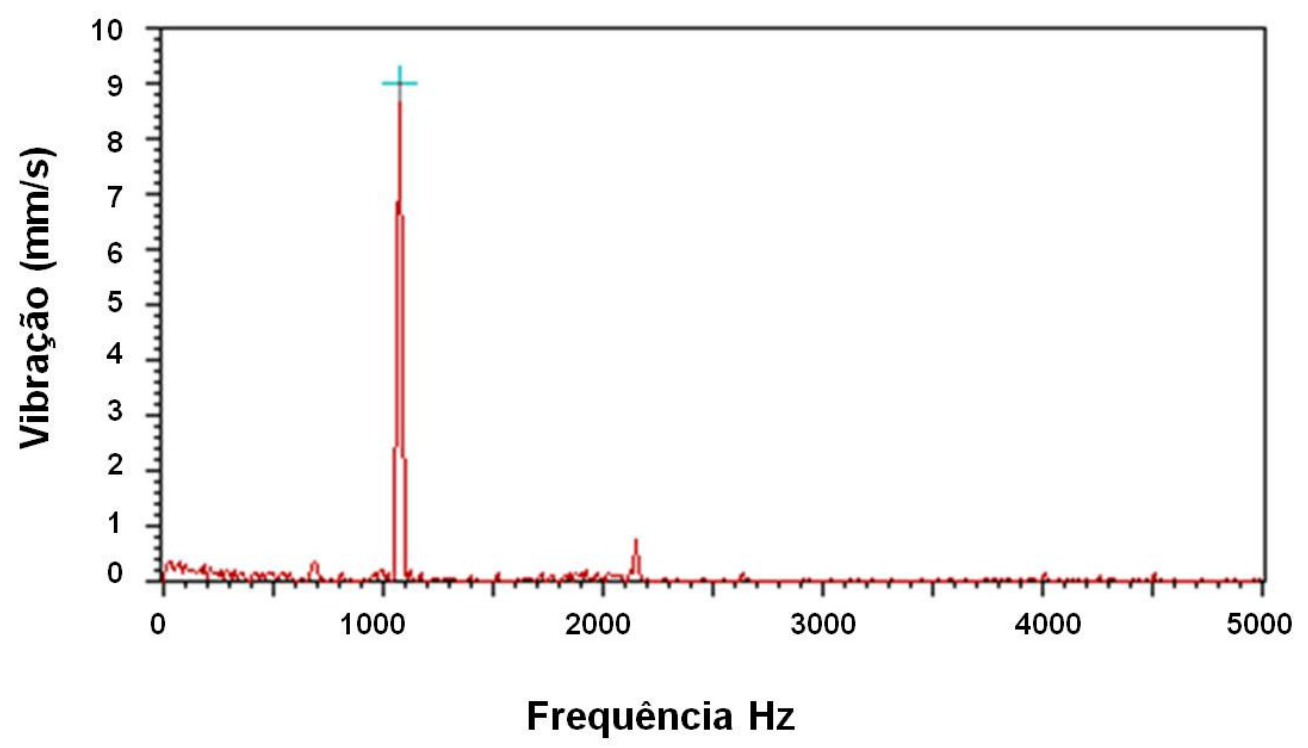

Figura 4.6 (a) - Espectro de frequências de compressor centrífugo com desbalanceamento Fonte: STEVENS, 2011, adaptada 


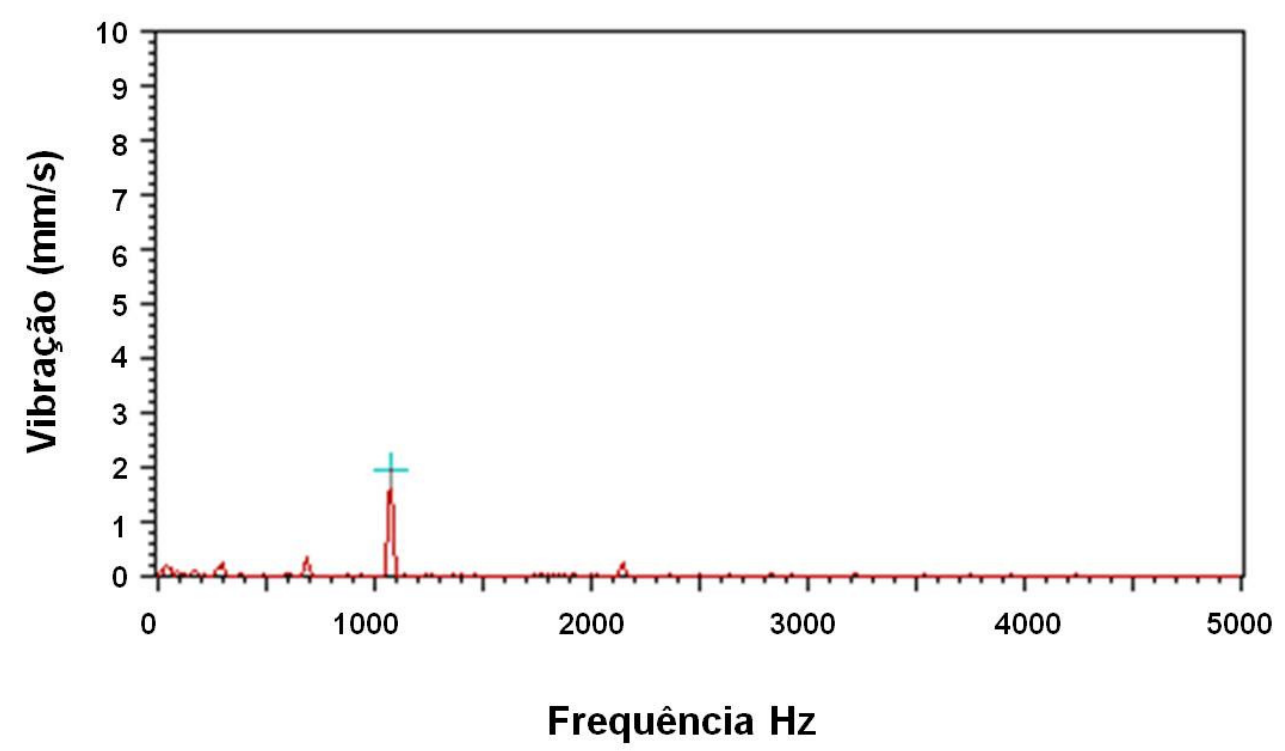

Figura 4.6 (b) - Espectro de frequências do compressor centrífugo após balanceamento Fonte: STEVENS, 2011, adaptada

\subsubsection{Análise por Ultrasom/Emissão Acústica}

Em funcionamento, todos os equipamentos emitem sons, audíveis ou não. Em condições normais emitem um espectro sonoro, ou "assinatura", que podem ser reconhecidos. Qualquer mudança nessa assinatura pode significar uma situação de desgaste ou deterioração em algum componente. $\mathrm{Na}$ análise por ultrasom, as formas de onda detectadas, seus padrões, bem como a intensidade do sinal indicam a severidade do desgaste. Fora do alcance do ouvido humano, o ultrasom é definido como onda sonora com frequência acima de $20 \mathrm{kHz}$, sendo que a técnica emprega aparelhos com faixa de trabalho entre 20 a $100 \mathrm{kHz}$.

A técnica de ultrasom pode ser empregada de duas formas distintas, ou seja, na detecção de ruídos emitidos pelos equipamentos e na avaliação de espessuras, corrosão e falhas internas de materiais, ferrosos ou não, tais como tanques e tubulações. Apesar de utilizar o mesmo princípio detectivo, os métodos e aparelhos de medição são diferentes.

No caso de detecção de ruídos, a medição pode ser baseada em medições à distância ou não. Nas medições à distância, não intrusivas, de visada direta da superfície do equipamento, o ultrasom pode ser empregado para verificação de vazamentos, tais como os que acontecem em sistemas de ar comprimido, de 
distribuição ou contenção de água, de vapor, de vácuo e de gases. Um fluído, componente do sistema em funcionamento, comprimido, ao vazar através de um pequeno orifício cria uma turbulência intensa, não audível pelo ser humano, mas detectável pelo aparelho de ultrasom. Mais recentemente essa técnica também vem sendo utilizada em sistemas elétricos. Num caso de anomalias, a ionização das moléculas de ar em volta do ponto com defeito do equipamento elétrico produz certo nível sonoro que pode ser detectado (IAEA, 2007). Embora de maior dificuldade, devido às condições de acesso, a medição realizada diretamente no equipamento também é muito utilizada, fornecendo os mesmos resultados daquelas feitas à distância. Uma das aplicações de ultrasom onde essa condição é bastante usada é na identificação de rolamentos com defeito.

Quando empregada para medição de espessuras, corrosão e descontinuidades de materiais essa técnica é mais conhecida como Emissão Acústica, sendo reconhecida como um ensaio não destrutivo (END). Nesse caso, os sensores do aparelho de medição devem ser posicionados diretamente no equipamento a ser avaliado, o que exige bom acesso às partes do sistema. $\mathrm{A}$ velocidade e a intensidade com que o sinal é transmitido ou refletido para um sensor revelam graficamente a presença de defeitos ou descontinuidades no material sob análise. Para mitigar possíveis dificuldades de acesso, Nicásio (2009) sugere adotar a técnica LORUS (Long Range Ultrasonics System), especialmente desenvolvida para detecção de corrosão à distância em equipamentos instalados em locais nessa situação, tais como, tubulações ou vasos sob suporte, tubulações isoladas termicamente, chapas de tanques, nas regiões de suportes e sob chapas de reforço em bocais e juntas de geometria complexas.

Sendo um dos métodos com maior possibilidade de uso na área predial, o ultrasom pode ser aplicado a dispositivos mecânicos com "assinaturas" conhecidas. Realiza-se a medição e análise do equipamento em condições normais de funcionamento. As medições e análises posteriores são comparadas a essa inicial. Qualquer desvio pode sofrer uma análise mais apurada e, se for o caso, tomada uma medida de correção.

Ainda com relação à detecção de ultrasom à distância, cabe lembrar que nessa técnica o som se propaga em linha reta e não penetra em superfícies sólidas, portanto, o operador do equipamento de medição precisa estar posicionado 
relativamente perto da fonte que se deseja analisar para um diagnóstico preciso (SULLIVAN et al., 2010).

Os equipamentos onde a técnica de análise por ultrasom pode ser utilizada são: compressores, chillers, condensadores, evaporadores, tanques de armazenamento de líquidos ou de gases, tubulações de água, de ar comprimido ou de gases, redutores de rotação, válvulas, equipamentos elétricos, tais como, transformadores, junções, isoladores, cabos de energia e disjuntores em média tensão. Os principais defeitos que o método consegue identificar são: vazamentos de fluídos, defeitos em rolamentos e em engrenagens, falta de lubrificação, cavitação, perda de espessura e defeitos em tubulações, tanques de armazenamento e vasos de pressão, etc. Em equipamentos elétricos de média tensão e acima, descarga Corona, descargas parciais, presença de arcos, perda de isolamento, vibrações anormais.

\subsubsection{Exemplo de aplicação}

a) Inspeção dos tubos de um trocador de calor (condensador ou evaporador) de uma máquina resfriadora de líquido (chiller): Uma máquina chiller é um dos equipamentos mais importantes e de maior custo individual num sistema de ar condicionado. Sua integridade é essencial para desempenho e confiabilidade satisfatório de todo o sistema. Um vazamento de refrigerante para o lado da água do sistema tem consequências catastróficas. A inspeção periódica dos tubos que compõem seus trocadores de calor (condensador e evaporador) é muito importante e uma das maneiras de prover operação segura da máquina. A técnica de ultrasom pode ser utilizada nesse trabalho. A figura 4.7.(a) mostra um equipamento de ultrasom sendo utilizado para medição de espessura dos tubos de um trocador de calor. 


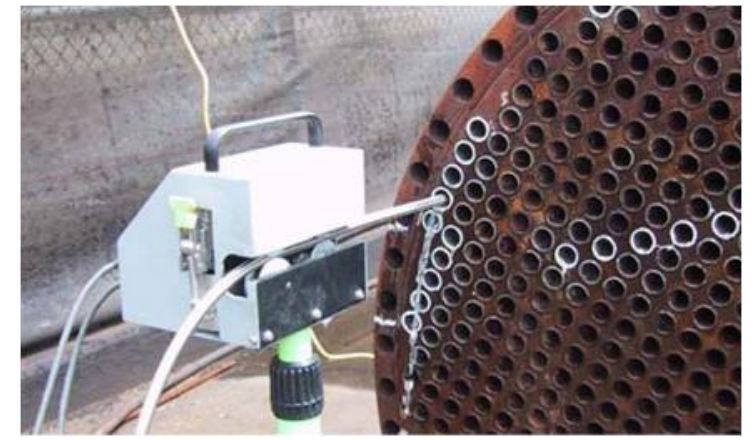

Figura 4.7 (a) - Medição de espessura num trocador de calor através da técnica de ultrasom Fonte: ENVIROCOUSTICS, 2011, adaptada

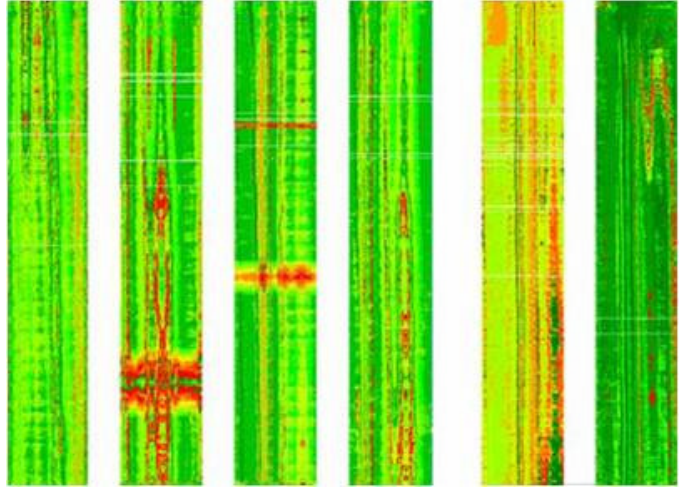

Figura 4.7 (b) - Resultados obtidos da inspeção por ultrasom

Fonte: ENVIROCOUSTICS, 2011, adaptada

$\mathrm{Na}$ figura 4.7.(b) podemos ver áreas em vermelho que indicam uma diminuição na espessura do tubo. No caso, quanto mais acentuada a cor vermelha, maior é a diminuição da espessura (ENVIROCOUSTICS, 2011).

\subsubsection{Análise de Óleo Lubrificante}

Dentre as técnicas de manutenção preditiva, talvez a que ofereça maior facilidade de execução seja a de análise periódica do óleo lubrificante de uma máquina. Além de propiciar indicação da degradação do equipamento, pode indicar baixa qualidade de serviços de manutenção, tais como, contaminação do lubrificante quando de sua substituição, adição de lubrificante inadequado, serviços de limpeza após manutenção, além de operação inadequada da máquina (SULLIVAN et al., 2010).

A análise de óleo lubrificante é utilizada para verificar três condições básicas relacionadas a uma máquina: o desgaste de seus componentes, a existência de sinais de contaminação e as condições do lubrificante. O desgaste da máquina pode ser determinado pela medição ou contagem de partículas de metal tais como, ferro, níquel, cobre, crômio, alumínio, chumbo e estanho. O aumento da presença de um metal específico pode significar que um determinado componente está se desgastando ou que a degradação está ocorrendo numa parte específica da máquina. A contaminação é normalmente provocada pela presença de água, por procedimentos de substituição inadequados, mistura de lubrificantes, meio ambiente 
(partículas suspensas no ar, gases, etc). A verificação da condição do lubrificante é importante para definição do estado de sua degradação ou situação perante os parâmetros de aceitação de uso (NASA, 2008).

\subsubsection{Principais testes em óleo lubrificante}

Os seguintes testes podem ser realizados numa análise de óleo lubrificante (SOUZA, 2011; CONNER, 2011):

a) Viscosidade: é a resistência ao escoamento oferecida pelo lubrificante a uma dada temperatura. Varia com a temperatura. É uma das mais importantes características do óleo lubrificante e sua determinação fornece um número específico que serve para comparar com uma condição recomendada para o óleo em serviço. A variação de seu valor pode indicar reposição de lubrificante de menor ou maior índice ou contaminação.

b) Teor de Água: Mede a quantidade de água presente no lubrificante. A existência de água acima de limites estabelecidos prejudica seriamente as propriedades do lubrificante e contribui para deficiência de lubrificação, formação de borras e corrosão dos componentes da máquina. $\mathrm{O}$ crescimento da concentração de água indica a possibilidade de presença de condensação, vazamento de refrigerantes ou vazamentos através de selos mecânicos.

c) Número de Acidez Total (TAN - Total Acid Number): Mede a acidez do lubrificante. A acidez total, resultado da oxidação do óleo, degrada as condições do lubrificante e contribui para a corrosão interna dos componentes da máquina. Inicialmente baixo, seu valor aumenta com o uso.

d) Número ou Índice de Neutralização (TBN - Total Base Number): Muitos lubrificantes recebem aditivos alcalinos para combater a formação de agentes ácidos. Esse teste mede a alcalinidade do óleo. No início da vida útil do lubrificante esse valor é alto, diminuindo com seu uso. 
e) Contagem de Partículas: Mede o tamanho e a quantidade de partículas no lubrificante. Indicado para sistemas onde a limpeza do lubrificante é importante e colabora para aumento de sua própria vida útil, bem como com o menor desgaste da máquina e seu desempenho.

f) Ferrografia: Análise das partículas de metal presentes numa amostra de óleo lubrificante. As partículas são identificadas de acordo com tipo de metal, suas dimensões e aspecto. Permite identificar o estágio de desgaste dos componentes de uma máquina e sua provável localização.

g) Espectroscopia de Emissão Atômica por Plasma Acoplado Indutivamente ou ICP Espectroscopy (Inductively Coupled Plasma Espectroscopy): Método de grande precisão, é capaz de identificar mais de 21 metais diferentes, classificados em metais que provocam desgaste, que contaminam ou que são utilizados como aditivos para o óleo. Essas informações auxiliam na determinação do desgaste da máquina e na verificação da condição do óleo lubrificante.

h) Espectroscopia de Infravermelho por Transformada de Fourier ou FTIR Spectroscopy (Fourier Transform - Infrared Espectroscopy): Faz a análise da composição química do lubrificante e permite identificar aditivos, contaminantes e causas da perda de qualidade do óleo. Grande precisão.

A análise de óleo lubrificante possui um campo restrito de aplicação em sistemas de ar condicionado predial, se limitando a máquinas chiller, compressores de ar e redutores de rotação.

\subsubsection{Análise Termográfica ou por Infravermelho}

A análise termográfica ou por infravermelho, ou ainda simplesmente, termografia, como é habitualmente mencionada, possui grande facilidade de aplicação em sistemas elétricos e por isso talvez seja a técnica mais empregada na inspeção de sistemas com manutenção baseada na condição. Essa técnica consiste na aplicação de instrumentos de detecção de radiação do infravermelho para 
identificação de diferenças de temperaturas. É uma técnica não intrusiva, baseada em medições à distância, de visada direta da superfície do corpo sob verificação, que mede e produz uma imagem térmica do ponto sob inspeção. Instrumentos com essa tecnologia são capazes de detectar comprimentos de ondas eletromagnéticas na faixa de radiação infravermelha entre 3 a 15 microns. Principalmente empregada em sistemas elétricos, também é utilizada em equipamentos mecânicos, caldeiras e fornos (NASA, 2008).

A termografia pode ser dividida em quantitativa e qualitativa. A inspeção quantitativa busca medir com precisão a temperatura do corpo sob investigação. Para tanto, a inspeção termográfica quantitativa requer conhecimento detalhado das relações entre temperatura e irradiação, reflexão, emitância, fatores ambientais e as limitações do instrumento termográfico. Embora proporcione resultados muito precisos, exige muitos cuidados e tem pouca aplicação na área predial.

Com relação à termografia qualitativa, seu emprego é bastante difundido nos setores de manutenção das áreas industrial e predial. Tem como método principal identificar diferenças de temperatura entre pontos quentes e frios em equipamentos de mesma função e sob mesmas condições de regime de trabalho, instalados num mesmo local e sob mesmas condições ambientais. As medições e imagens assim obtidas são facilmente comparadas entre si e analisados os respectivos desvios em relação à temperatura normal ou faixas admissíveis, muitas vezes no próprio momento da realização da inspeção.

Ao contrário da inspeção quantitativa, no âmbito industrial e predial a inspeção termográfica qualitativa se mostra muito eficaz e rápida, uma vez que os fatores que influenciam a medição (irradiação, emitância, etc) são os mesmos para todos os itens sob inspeção, permitindo desprezá-los e focar somente nas diferenças de temperatura.

Cuidados devem ser tomados na aplicação de termografia. A visão direta do objeto sob análise é essencial. Materiais transparentes ao olho humano, tais como o vidro e o plástico, não o são para o aparelho de inspeção termográfica, representando um bloqueio, que leva a erros. Inspeções ao ar livre devem considerar as influências da radiação solar e do vento.

Num sistema de ar condicionado, o campo natural de aplicação da termografia são os equipamentos elétricos que o compõe, embora também seja aplicável a diversos componentes mecânicos desse mesmo sistema. A termografia é 
usualmente aplicada em equipamentos de baixa, média e alta tensão, tais como, painéis de distribuição, isoladores, barramentos, disjuntores, fusíveis, chaves, comutadores, contatores, capacitores, transformadores, reatores, geradores, conexões, capacitores, pára-raios, cabos, motores, tubulações e equipamentos termicamente isolados, etc. A adoção da técnica permite identificar nos equipamentos elétricos citados: partes de equipamentos com aquecimento acima do normal; mau contato em conexões de cabos, chaves, disjuntores, fusíveis, transformadores, capacitores e barramentos, mau contato nos pólos de interruptores, chaves e disjuntores, trincas e perdas de isolamento em suportes isolantes elétricos, problemas de trocas de calor em transformadores com óleo isolante, aquecimentos localizados em transformadores secos, desbalanceamentos de correntes em circuitos de distribuição. Em motores elétricos: defeitos em sistemas de arrefecimento, lubrificação inadequada de rolamentos, defeitos em rolamentos, defeitos em acoplamento e alinhamento. Em tubulações e equipamentos com fluídos térmicos: perda de calor através do isolamento térmico, etc.

\subsubsection{Exemplo de aplicação}

\section{a) Defeito em rolamento de motor e em disjuntor de painel elétrico}

As figuras 4.8.(a) e 4.8.(b) mostram respectivamente defeitos em um motor elétrico e num disjuntor de painel de distribuição de energia.

Na figura 4.8.(a) temos a aplicação da técnica num típico defeito mecânico, ou seja, um motor elétrico com defeito em rolamento na ponta de eixo, lado acoplado, evidenciado pela grande diferença de temperatura em relação ao restante da máquina (nesse caso, quanto mais amarela a imagem, mais quente está 0 ponto/região). 


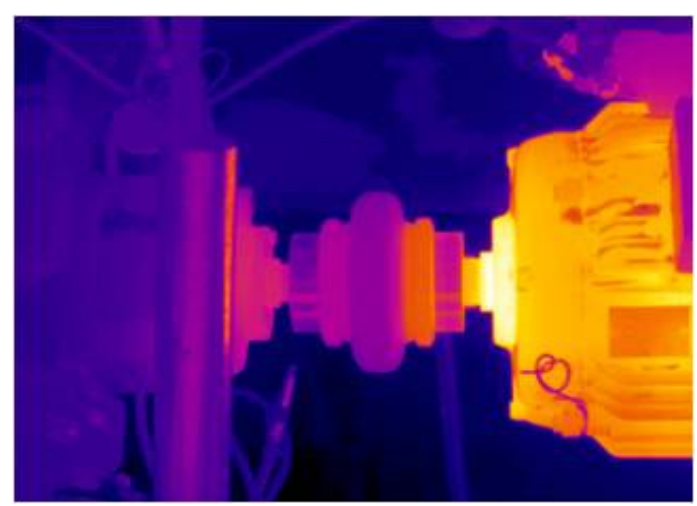

Figura 4.8 (a) - Imagem termográfica de motor com defeito em rolamento do lado acoplado Fonte: NASA, 2004

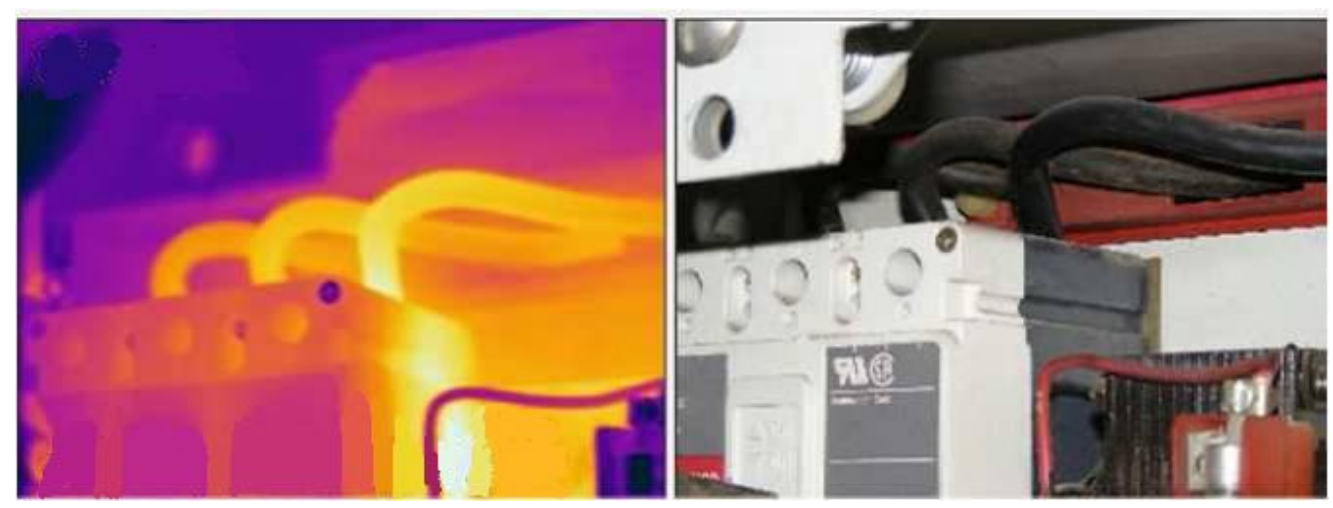

Figura 4.8 (b) - Disjuntor com sobreaquecimento nas fases $\mathrm{S}$ e T Fonte: SMITH, 2011

Na figura 4.8.(b) temos um disjuntor trifásico com forte sobreaquecimento nas fases S e T. Pela análise da figura, pode-se notar que o defeito provavelmente teve origem na fase $\mathrm{T}$, talvez devido a uma alta resistência de contato.

\subsubsection{Resistência Ôhmica de Enrolamentos}

Uma das mais simples checagens que pode ser feita, a resistência ôhmica de enrolamentos pode ser realizada em qualquer tipo de bobinamento elétrico. Dois são os objetivos principais da aplicação dessa técnica: (i) detectar perda de conexão elétrica e bobinas/espiras abertas, e, (ii) avaliar e comparar as resistências medidas nas diversas fases do bobinado do equipamento, para identificação de curtoscircuitos entre bobinas e entre espiras (INO, 2011). 
É uma técnica de avaliação simples e de rápida execução, tanto no recebimento de um equipamento novo, quanto daquele que retorna de um reparo, bem como para aqueles em serviço que apresentem alguma anomalia ou falha de funcionamento (ADWEL, 2011).

Seu maior campo de aplicação são os motores, transformadores, geradores e reatores elétricos de qualquer capacidade. Embora não usual pode se utilizada também para verificação do estado de bobinas de comando de equipamentos cuja operação seja essencial para a confiabilidade e segurança de um processo ou para as pessoas.

\subsubsection{Resistência Ôhmica de Contato}

Um sistema elétrico é composto em grande parte por dispositivos de seccionamento e proteção tais como comutadores, chaves e disjuntores. Tais equipamentos possuem além da função de liberar ou interromper a passagem de corrente elétrica de um circuito, conforme o comando recebido, de proporcionar uma conexão ou ligação elétrica de baixa resistência à passagem de corrente, quesito esse essencial para operação adequada e segura do equipamento. Essa função é desempenhada pelo pólo do equipamento, peça essa constituída de um par de contatos elétricos, normalmente sendo uma das peças móvel e a outra fixa, como mostrado na figura 4.9, (a) e (b) (MENSAH, 2011).

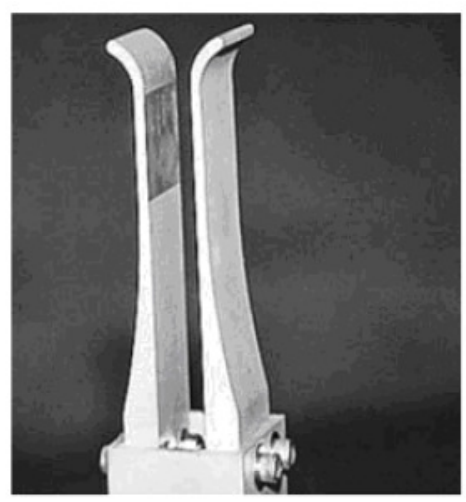

(a) Contato Fixo

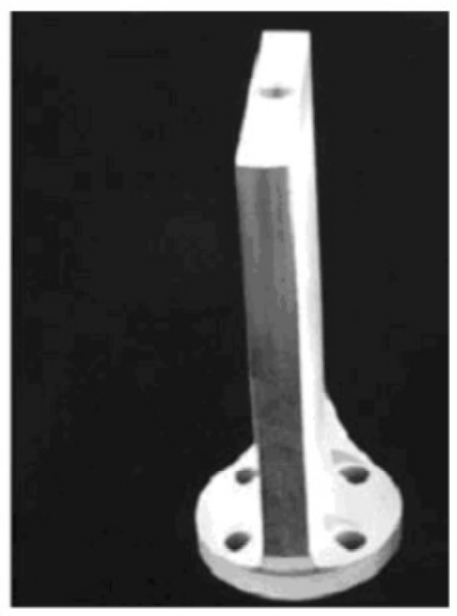

(b) Contato Móvel

Figura 4.9 - Fotos de um par de contatos elétricos Fonte: MENSAH, 2011, adaptada 
Devido à rugosidade natural dos materiais, ao se estabelecer uma junção entre dois metais, somente parte de suas superfícies irá contribuir para a formação do contato elétrico. Será por essa área real de contato, menor que a área total teórica, que toda a corrente elétrica do circuito irá circular. $O$ valor da resistência de contato será mínimo quando as superfícies e a pressão de contato estiverem em boas condições. Ocorre que mesmos em condições normais, devido às rugosidades naturais e à passagem de corrente, compostos químicos e óxidos acabam se formando nas superfícies dos materiais, levando ao aumento paulatino da resistência de contato. Por outro lado, em casos de estresses, esses agentes químicos se formam mais intensamente e num curto período de tempo, acelerando bastante esse processo. $\mathrm{O}$ aumento da resistência de contato devido a qualquer dessas situações, causa a sobreelevação da temperatura na área de junção, que por sua vez contribui para aumento da resistência, o que leva a uma temperatura ainda maior. Esse processo de deterioração é cada vez mais incrementado e, se não identificado a tempo, pode levar a falhas catastróficas (MENSAH, 2011; WHITE, 2007).

Além do funcionamento normal, as razões que podem levar a estresse das superfícies dos materiais e uma alta resistência de contato podem ser (WHITE, 2007):

- Desgaste das superfícies de contato devido ação mecânica, ou seja, atritos e desajustes entre as peças que compõem o pólo, que acontecem durante o movimento de abrir/fechar.

- Picos e surtos de tensão e corrente que ocorrem devido a fenômenos elétricos que surgem durante o chaveamento e provocam desgaste das superfícies de contato do pólo.

- Falta de adequada pressão de contato, devido a desajustes nos mecanismos de acionamento dos pólos.

As figuras 4.10, (a), (b) e (c) mostram a situação de contatos de disjuntores sob diversas condições de desgaste. 


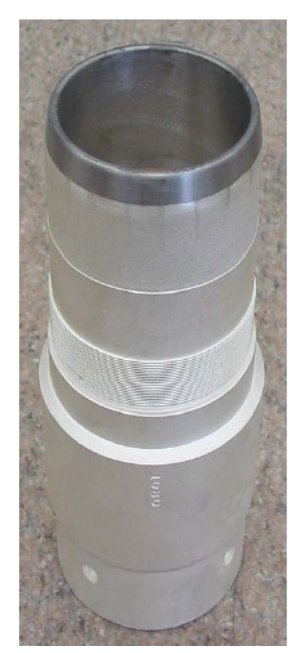

(a) Contato móvel Sem uso

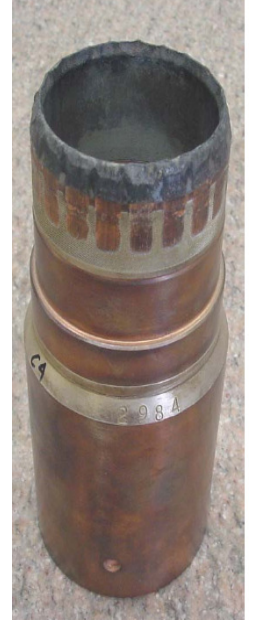

(b) Contato móvel após uso

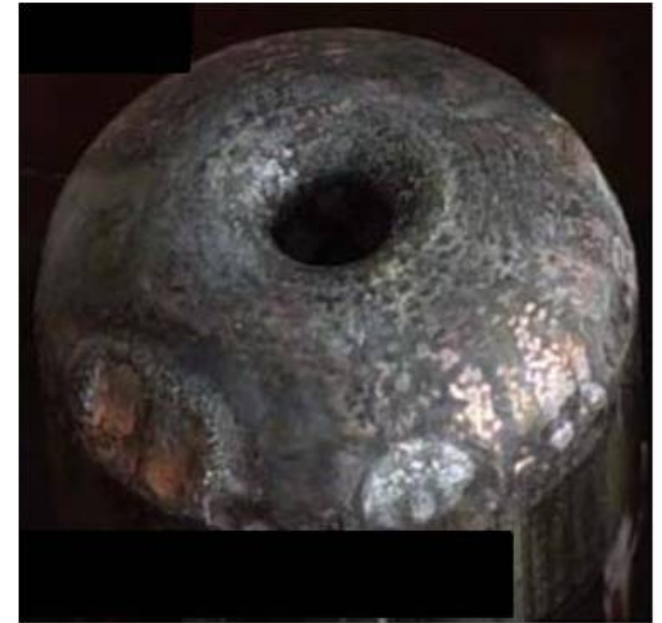

(c) Contato fixo com danos na superfície

Figura 4.10 (a), (b) e (c) - Situação de contatos elétricos de disjuntores Fonte: LANDRY et al., 2006, adaptada

Na figura 4.10.(a) temos a visão de um contato móvel de disjuntor, sem uso, com suas superfícies de contato em perfeitas condições. Para comparação, a figura 4.10.(b) mostra peça semelhante com alto grau de deterioração devido a arcos elétricos e desgaste mecânico. Já na figura 4.10.(c) temos um contato fixo com sinais de danos mecânicos com perda de material e superfície bastante deteriorada.

\subsubsection{Resistência Ôhmica de Isolamento}

Os componentes e equipamentos elétricos, tais como, motores, transformadores, reatores, cabos, etc, são constituídos de condutores elétricos de energia isolados ou montados sobre suportes isolantes. Teoricamente, não existem perdas de corrente num condutor elétrico isolado, porém na condição real de uso uma parte dessa corrente consegue atravessar o material isolante devido a inúmeras causas. Impossível de ser eliminada, a assim chamada corrente de fuga, não deve ultrapassar um valor máximo admissível, de maneira a preservar as plenas condições operacionais do equipamento, bem como garantir segurança às pessoas (GREGOREC, 2006).

Nas máquinas elétricas, transformadores, motores, etc, os condutores elétricos são montados em forma de espiras para formação de bobinas de indução. 
Para esse formato construtivo, o condutor recebe três barreiras de isolamento elétrico. A primeira é um verniz de revestimento do condutor. A segunda barreira, formada por folhas isolantes separa as bobinas entre si, e, uma terceira separa 0 conjunto assim formado da massa (ou terra) do equipamento. Cabos de distribuição de energia recebem em geral, uma ou duas camadas de revestimentos, uma de isolação e outra de proteção contra choques mecânicos e abrasão. Cabos de média tensão e acima recebem outros tipos de camadas adicionais com a finalidade de alívio de tensão.

Ocorre que o tipo de construção citado é similar e se comporta como um capacitor, onde temos dois potenciais elétricos, no caso o condutor energizado numa tensão $V_{1}$ e um potencial de terra $V_{2}$, normalmente de zero volt, separados por um dielétrico, justamente os materiais de isolamento elétrico citados.

Com as máquinas e cabos elétricos em funcionamento, esses materiais isolantes ficam sujeitos a vários esforços e condições de degradação. As causas da deterioração de um material isolante são (NASA, 2004; US-DOI, 1991):

- Vazios e defeitos nos materiais, produzidos durante o processo de fabricação.

- Vazios provocados pelos processos de montagem nas máquinas elétricas.

- Estresses elétricos, devidos a impulsos, sobretensões e curtos-circuitos.

- Estresses mecânicos, cujas origens podem ser devido a esforços elétricos, defeitos de montagem/reparos, vibrações mecânicas e vibrações elétricas relativas à frequência de operação da rede de energia.

- Contaminação devida ao meio ambiente, como por exemplo, umidade, poeira, sujidades diversas, bem como, ataque de produtos químicos, como por exemplo, óleos, graxas, ácidos, etc., que acabam impregnando o isolamento.

- Esforços térmicos, que ocorrem devido operação a altas temperaturas em longos períodos, expansão e contração dos materiais.

- Envelhecimento do material isolante sob condições normais de temperatura e funcionamento.

Por meio do teste de resistência ôhmica de isolamento, baseado no conhecimento do princípio de funcionamento dos capacitores é possível 
acompanhar o estado de degradação dos materiais isolantes e tomar ações de reparo de modo planejado, evitando maiores perdas e consequências.

Ao se aplicar uma tensão contínua num isolante surgem três correntes: a condutiva $I_{L}$, a capacitiva $I_{C}$ e a de absorção $I_{A}$. $I_{T}$ é a corrente total e corresponde à soma dessas três.

A corrente $I_{L}$ ou de fuga é a que flui normalmente através do isolante e não deve ultrapassar um valor máximo pré-definido em acordo com a categoria do equipamento. À medida que o material isolante se deteriora essa corrente aumenta. Numa situação de teste de isolamento em tensão DC, caso o material isolante esteja em bom estado, essa corrente cresce por um período e depois se estabiliza, como pode ser visto na figura 4.11 (FLUKE, 2007).

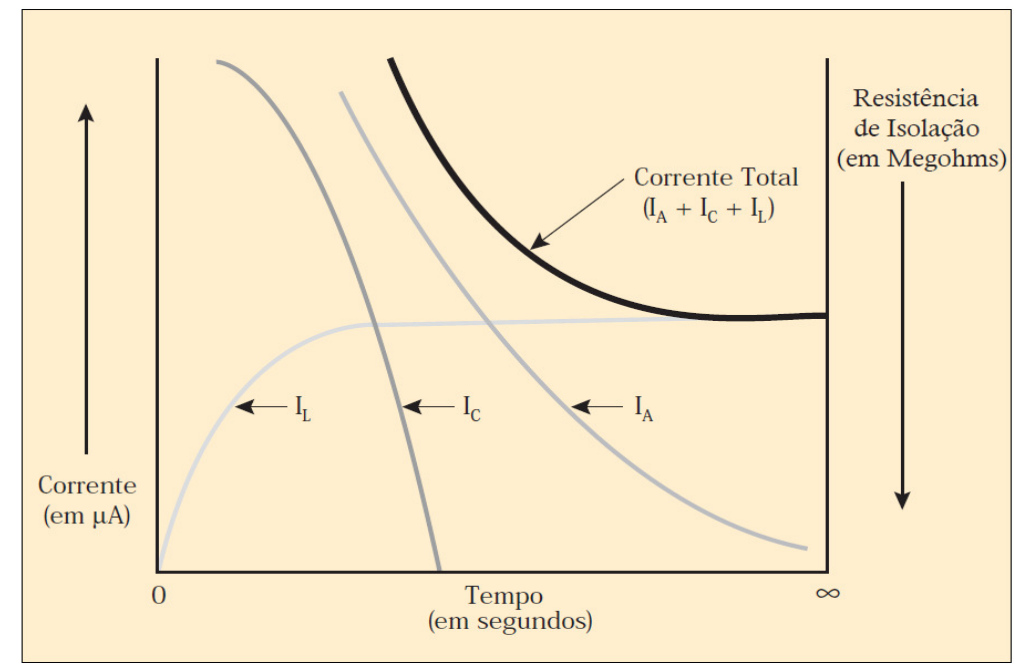

Figura 4.11 - Correntes DC que circulam numa boa isolação Fonte: FLUKE, 2007

Ainda na figura 4.11 notamos que a corrente capacitiva $I_{c}$ apresenta inicialmente um alto valor que diminui, deixando de existir após um período de tempo em virtude do efeito capacitivo provocado pelo processo construtivo, conforme já citado. Também inicialmente alta, a corrente de absorção $I_{A}$ deve-se à polarização das moléculas do material isolante. De efeito semelhante ao capacitivo, diminui após um período de tempo. Finalmente, essa mesma figura mostra a curva da corrente $\mathrm{I}_{\mathrm{T}}$ e se pode ver que o valor da resistência de isolamento é inversamente proporcional às correntes que circulam pelo isolante (FLUKE, 2007).

Desse modo, a resistência de isolação pode ser obtida de forma global e assim é praticada, mas conhecer cada dessas correntes torna possível identificar possíveis agentes de degradação do material isolante. Assim, dentre os mais 
variados motivos, a corrente $I_{L}$ ou de fuga pode indicar o quanto a isolação está deteriorada por causa de esforços mecânicos e elétricos. Corrente $I_{C}$ que não diminui ao longo do tempo ou se mantém alta mostra a presença de contaminantes, umidade. Comportamento semelhante da corrente $I_{A}$ leva à conclusão que o material isolante pode estar sob ação de efeitos térmicos, contaminação (FLUKE, 2007).

Diversas técnicas são utilizadas para medição da resistência ôhmica de isolação, desde aquelas mais simples e rápidas, até mais sofisticadas e de maior tempo de execução, porém o conceito por trás de todas é sempre o mesmo, ou seja, quanto maior o valor medido, melhor a condição operacional do equipamento e mais seguro o seu funcionamento.

As técnicas comumente mais empregadas são:

\subsubsection{Isolamento a 1 minuto}

Aplicado durante 1 minuto e a tensão constante. Ao final de 1 minuto o valor de isolamento é registrado e apontado num gráfico, como o de acompanhamento de um motor da figura 4.12, onde se mostra a curva histórica das medições realizadas para fins de análise comparativa, o que permite analisar a tendência (estabilidade ou decréscimo) da resistência de isolamento.

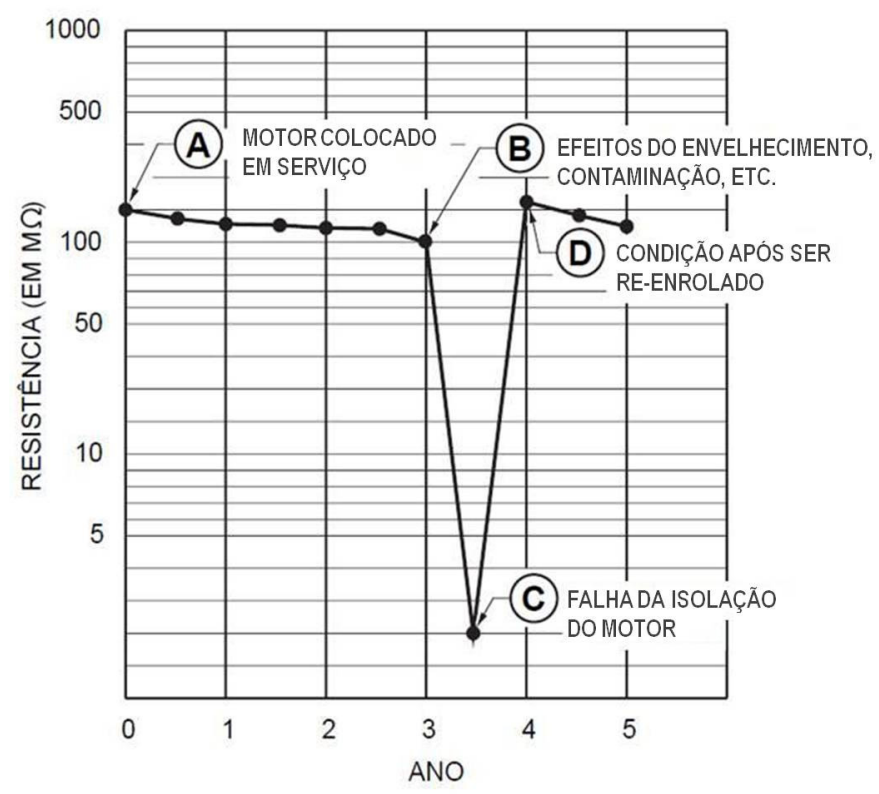

Figura 4.12 - Gráfico de acompanhamento da resistência de isolamento a 1 minuto de um motor elétrico

Fonte: ATP - FLUKE, 2005, adaptada 
De fácil e rápida execução esse teste possibilita o diagnóstico da presença da existência de umidade, óleo ou acúmulo de poeira. Uma queda acentuada no valor da resistência pode indicar uma falha de isolação (EC\&M, 2002).

\subsubsection{2. Índice de Absorção (IA)}

O teste é realizado durante 60 segundos, sob tensão constante. Aos 30 e aos 60 segundos são feitos os registros das resistências de isolação. $O$ índice de absorção é o resultado da divisão do valor encontrado em 60 segundos pelo registrado em 30 segundos. A isolação é considerada boa quando a relação apresentar um valor mínimo de 1,3 (FLUKE, 2007).

\subsubsection{3. Índice de Polarização (IP)}

Técnica realizada durante 10 minutos ininterruptamente, a tensão constante. No primeiro minuto do teste é realizado o registro do valor de isolação. Desse instante em diante é feito o registro a cada minuto até o décimo minuto. Com esses dados é possível traçar um gráfico como o da figura 4.13 .

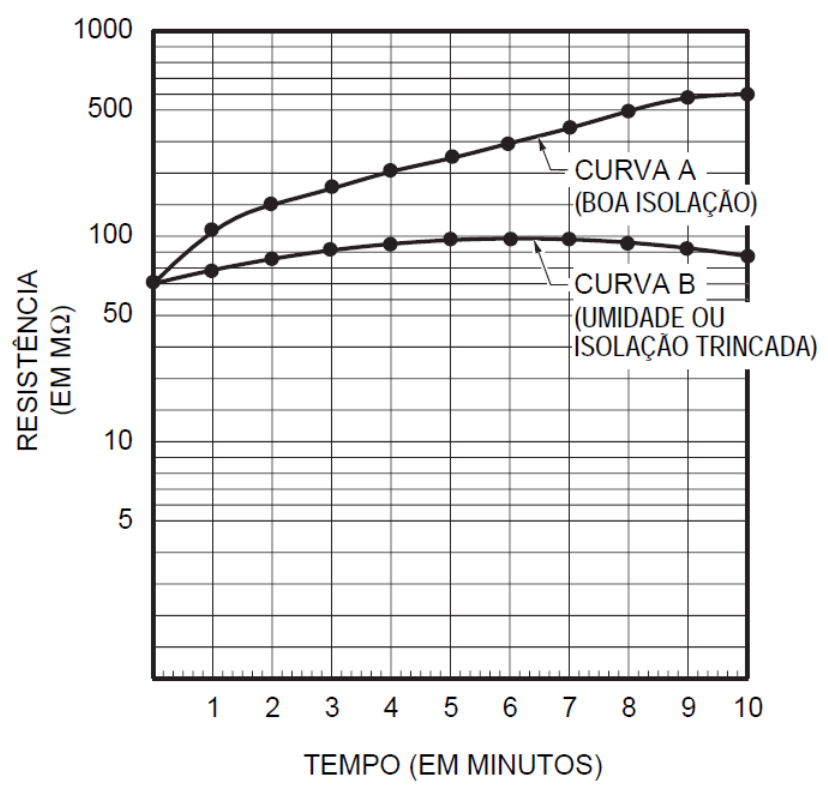

Figura 4.13 - Gráfico de tendência da resistência de isolamento durante um teste para obtenção dos índices de absorção e de polarização

Fonte: ATP - FLUKE, 2005, adaptada 
Nesse gráfico a inclinação das curvas indicam a condição da isolação sob teste. Enquanto um bom isolamento mostra um contínuo crescimento do valor da resistência, como mostrado na curva "A", um isolamento inaceitável, com pouca variação de sua resistência, devido contaminação ou umidade, é indicado na curva "B".

O valor do índice é obtido da divisão do valor da isolação a 10 minutos pelo valor a 1 minuto e deve, para uma boa isolação, resultar numa relação maior que 2,0 (FLUKE, 2007).

Os índices de absorção e polarização são também conhecidos como testes tempo-resistência e são capazes de detectar as mesmas irregularidades do teste de isolação a 1 minuto e ainda possíveis curtos entre espiras do bobinamento do motor. Possuem como vantagem além da independência da temperatura, maior precisão em relação ao teste de 1 minuto. A utilização do teste IP é sempre melhor e deve ser preferido em relação à aplicação do teste a 1 minuto e IA, que somente devem ser executados em casos de restrição de tempo (FLUKE, 2007).

\subsubsection{Resistência de isolamento sob múltiplas tensões de teste}

Mais conhecida como técnica de degrau de tensão ou step-voltage test, consiste na aplicação de degraus de tensão, múltiplos do valor mais baixo numa relação 1:5, durante um período de tempo fixo de 60 segundos para cada uma das tensões e tem a capacidade de submeter a isolação a um estresse temporário, porém sem danos ao material. Em geral esse teste inicia com valores de 250 ou 500 volts para máquinas de baixa tensão. Para cada degrau de tensão anota-se 0 respectivo valor de resistência de isolamento (FLUKE, 2007). A figuras 4.14.(a) e 4.14.(b) mostram gráficos com resultados desse tipo de teste. 


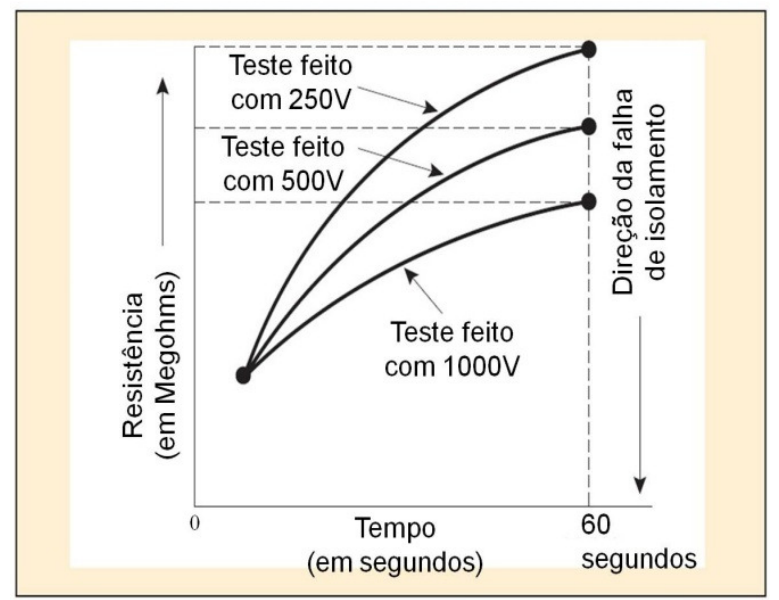

Figura 4.14 (a) - Curvas de resistência de isolação para diferentes tensões de teste Fonte: FLUKE, 2007, adaptada

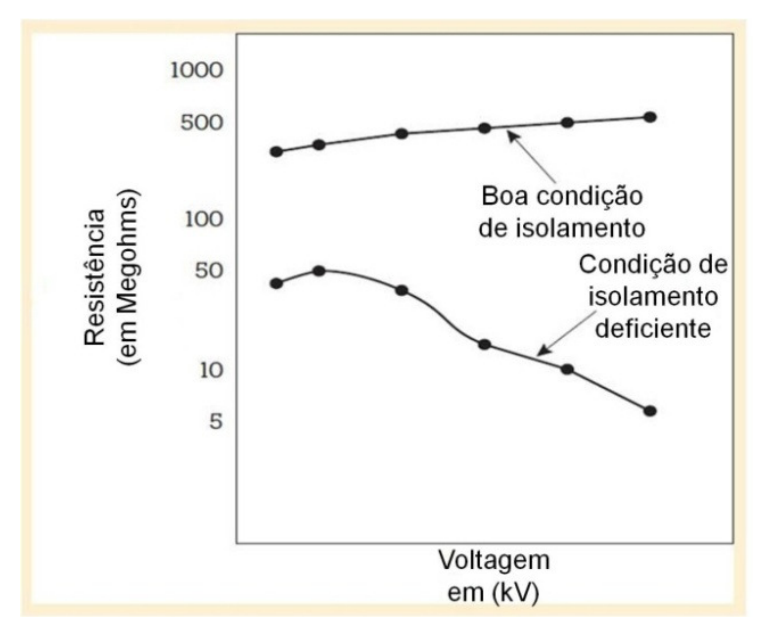

Figura 4.14 (b) - Curvas de tendência para resistência de isolação sob diferentes tensões de teste

Fonte: FLUKE, 2007, adaptada

$\mathrm{Na}$ figura 4.14.(a), as curvas mostram uma situação de degradação da resistência de isolamento com a aplicação de degraus de tensão. Percebe-se uma diminuição da isolação na medida que a tensão aplicada aumenta. No caso da figura 4.14.(b) temos a representação de duas curvas, onde uma delas, curva "A", mostra uma situação de boa condição de isolamento, com pouca variação à medida que a tensão de teste aumenta. Já na curva "B", notamos que ao aumentar a tensão de teste, a resistência de isolamento cai muito, indicando defeito no enrolamento.

A medição de resistência de isolamento sob múltiplas tensões de teste possui capacidade de diagnosticar defeitos no material isolante, tais como, furos, trincas e curtos-circuitos (FLUKE, 2007).

\subsubsection{Teste de impulso}

Conhecido também como surto elétrico ou surge test, trata-se da aplicação de um breve impulso de tensão na bobina do motor. Esse impulso cria um gradiente de tensão ao longo de todo o comprimento do fio, que termina por provocar um estresse momentâneo entre as espiras da bobina. A bobina irá produzir uma forma de onda senoidal amortecida, cuja forma de onda e frequência estarão diretamente relacionadas com suas características construtivas e possíveis defeitos existentes. Como no caso do step-voltage test, também não causa danos aos materiais. 
Segundo Lanham (2011), o surge test é especialmente indicado para identificação de baixas resistências de isolamento entre bobina e terra, entre espiras de uma bobina, entre bobinas e entre fases do bobinamento, o que nenhum dos outros métodos consegue realizar.

Finalmente, todas as técnicas de medição de resistência ôhmica de isolamento apresentadas tem seu campo de aplicação voltado às máquinas elétricas, dentre elas, motores e transformadores de qualquer tipo e capacidade, componentes, tais como, cabos elétricos, disjuntores, chaves seccionadoras, contatores, comutadores, capacitores, etc, de qualquer tensão de trabalho.

\subsubsection{Fator de Potência da Isolação e Fator de Dissipação}

Da mesma forma que a técnica de medição da resistência ôhmica de isolamento, aproveita o comportamento capacitivo da isolação das máquinas elétricas para obter informações a respeito de sua deterioração. Uma tensão conhecida é aplicada na isolação. A corrente resultante e a relação de fase corrente/tensão são medidas. A corrente total $\mathrm{I}_{\mathrm{T}}$ que atravessa $\mathrm{o}$ isolante é a resultante de duas correntes componentes, a corrente resistiva $I_{R}$ e a capacitiva $I_{C}$ como pode ser visto na figura 4.15. $\mathrm{I}_{\mathrm{C}}$ está defasada $90^{\circ}$ da tensão e $\mathrm{I}_{\mathrm{R}}$ está em fase (NASA, 2004).

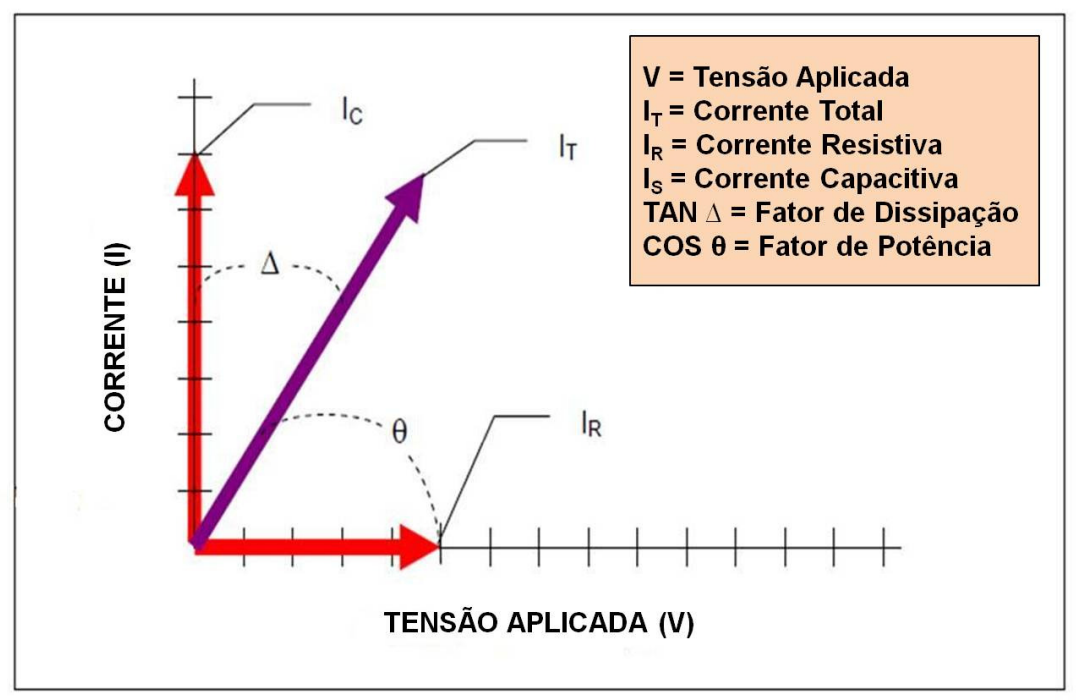

Figura 4.15 - Fator de potência da isolação - Relação entre as diversas correntes medidas Fonte: NASA, 2004, adaptada 
Da figura, temos (NASA, 2004):

Fator de Potência da isolação $=\operatorname{Cos} \theta=I_{R} / I_{T}$

, e;

Fator de Dissipação da isolação $=$ Tangente Delta $=\operatorname{tg} \Delta=\mathrm{I}_{\mathrm{R}} / \mathrm{I}_{\mathrm{C}}$

Numa situação de perfeitas condições da isolação, a corrente $I_{C}$ é muito maior que $I_{R}$. Na medida em que a isolação sofre alterações devido danos físicos, curtoscircuitos, umidade, contaminação ou envelhecimento, a resistência de isolamento diminui, provocando um aumento das correntes $I_{R}$, através do material isolante, e $I_{T}$. Com o aumento de $I_{R}$, $\circ$ ângulo $\Theta$ (fi) diminui e $\circ$ fator de potência aumenta, indicando a degradação do isolamento. Na medida em que o ângulo $\Theta$ (fi) diminui, o ângulo $\Delta$ (delta) aumenta, incrementando o fator de dissipação, indicando maiores perdas no dielétrico (circulação de corrente no isolante). Quanto maior o fator de potência da isolação, pior a qualidade do isolamento. Quanto maior a tangente Delta, maiores as perdas por dissipação no dielétrico. Uma consequência do aumento da corrente $I_{R}$ (ou de fuga) e do fator de potência é a elevação da temperatura no ponto do defeito, o que acelera ainda mais a degradação do material isolante (NASA, 2004).

\subsubsection{Análise de Circuito de Motor ou MCA (Motor Circuit Analysis)}

Método baseado em baixa tensão, MCA é uma técnica de aplicação exclusiva em motores elétricos que envolve o levantamento de seus parâmetros mais significativos, tais como, resistência ôhmica dos enrolamentos, resistência de isolamento dos enrolamentos para a terra, balanço de fases (impedância e indutância), ângulo de fase, corrente/resposta de frequência. Por meio desses dados é capaz de avaliar a condição das conexões elétricas, incluindo fiação de controle, a situação dos isolamentos elétricos de cabos de alimentação, dos enrolamentos do estator, do rotor, seja bobinado ou não, e, também, do entreferro entre estator e rotor. Tem como vantagens sobre as técnicas já apresentadas de avaliação de isolamento, a capacidade de detectar com maior precisão defeitos de isolação e em seu estágio inicial, bem como pode ser realizada a partir dos painéis elétricos de 
controle e alimentação dos motores, eliminando a necessidade de desconexão de cabos de alimentação/controle, diminuindo o tempo de parada do sistema ou equipamento (PENROSE, 2004; ALL-TEST PRO, 2005).

\subsubsection{Análise de Assinatura de Corrente de Motores ou MCSA (Motor Current Signature Analysis)}

Outra técnica de uso exclusivo em motores elétricos e também por meio de instrumento específico, o método MCSA é baseado no reconhecimento de que um motor elétrico convencional ao acionar uma máquina também age como um eficiente e permanente transdutor. O campo magnético formado entre estator e rotor tem relação direta com a variação da carga mecânica aplicada ao eixo do motor, tendo como consequência a modulação da corrente que flui pelos enrolamentos do estator e cabos de alimentação. Qualquer anomalia ou defeito tanto no motor ou na carga acionada, afeta esse campo magnético, que por sua vez reproduz essa situação na corrente elétrica que circula. Esse fenômeno gera uma "assinatura" ou um sinal elétrico na corrente que pode ser decomposto em frequência e amplitude. Por meio da monitoração e avaliação do espectro ou "assinatura" de corrente de uma das fases do motor é possível identificar a causa das anomalias detectadas. Os dados são levantados a partir do painel de comando e alimentação durante trabalho normal do equipamento (em serviço), evitando a paralisação do sistema (BONALDI et al., 2008; PILLAY; XU, 1996).

Segundo Penrose (2004) essa técnica é capaz de detectar:

- Defeitos nos cabos de alimentação do motor.

- Defeitos e falhas no estator e no rotor (barras quebradas, mau contato em barras soldadas, por exemplo).

- Excentricidade dinâmica e estática do entreferro.

- Defeitos em acoplamentos rígidos, por correias e por redutores de rotação.

- Problemas na carga acionada.

- Eficiência do sistema. 


\section{Exemplo de aplicação}

Nas figuras 4.16 e 4.17 que seguem vemos os espectros de frequência de corrente de um motor submetido à técnica MCSA.

A figura 4.16 indica que o mesmo está em boas condições. Note-se que a figura mostra um pico na frequência de linha $\mathrm{f}_{1}(60 \mathrm{~Hz})$ e dois picos laterais, menores, distanciados de duas vezes a frequência de escorregamento $f_{S}$ (LAMIN, 2003). Para fins de avaliação da condição é medida a diferença de amplitude ( 48 dB) entre $f_{l} e$ $\mathrm{f}_{\mathrm{l}}-2 \mathrm{f}_{\mathrm{s}}$ (a maior das bandas lateriais). As amplitudes de corrente apresentadas em $\mathrm{dB}$ são referenciadas à corrente de 1 Ampére (BRITO, 2002).

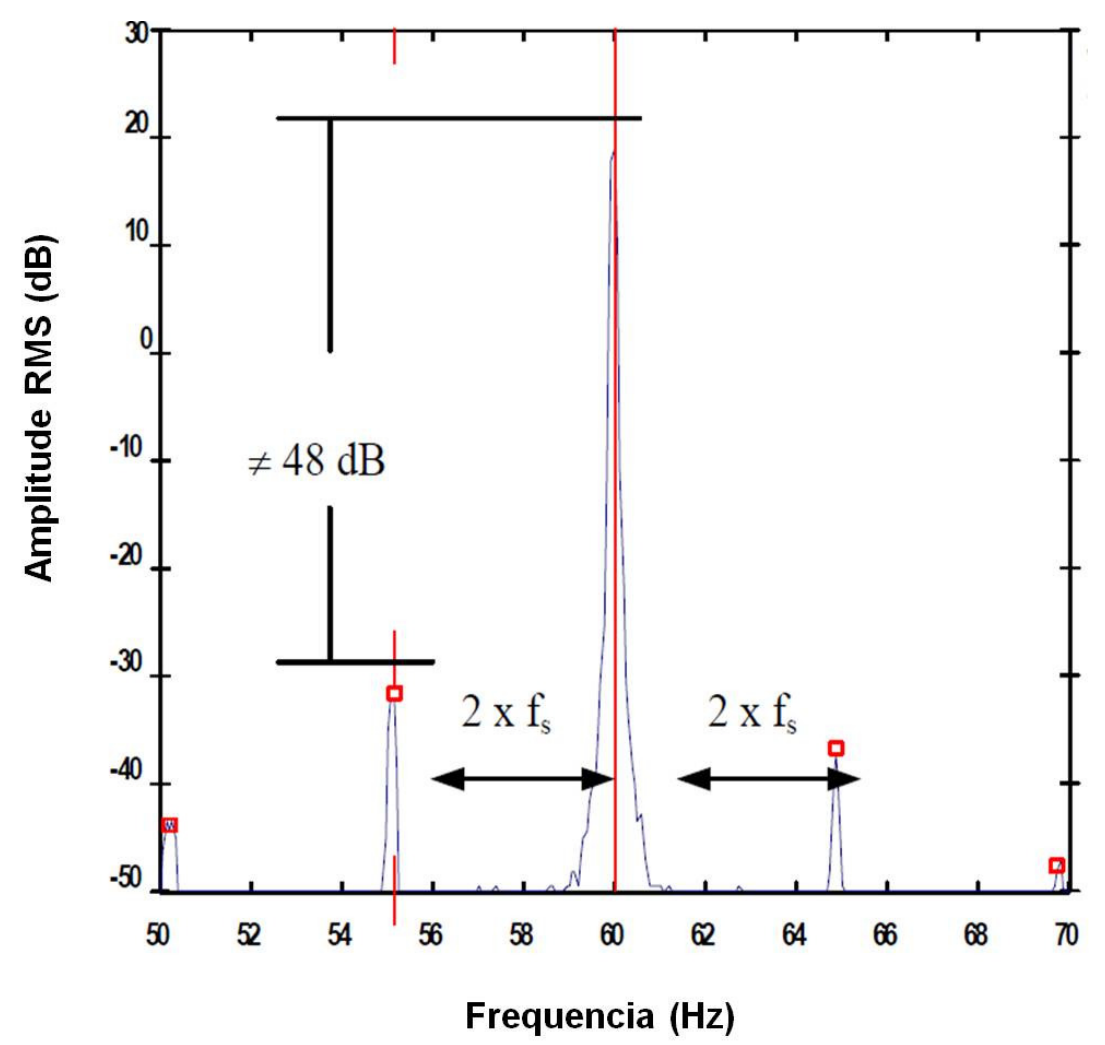

Figura 4.16 - Motor em boas condições de funcionamento Fonte: LAMIN, 2003, adaptada

$\mathrm{Na}$ figura 4.17 temos o mesmo motor, porém numa situação de 7 barras quebradas. As frequências levantadas se comportam do mesmo modo que no caso anterior, porém com uma diferença de amplitude bem menor ( $\sim 27 \mathrm{~dB}$ ) (LAMIM, 2003). 


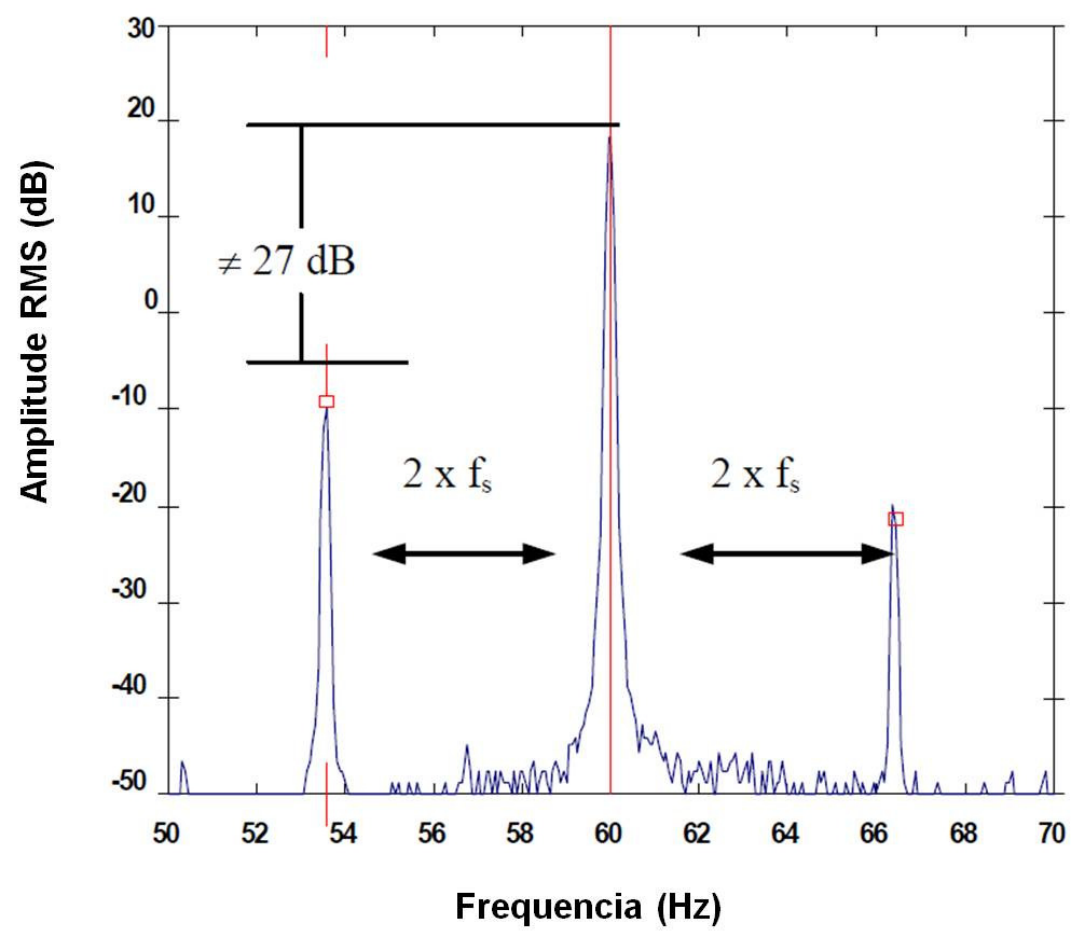

Figura 4.17 - Motor com rotor danificado Fonte: LAMIN, 2003, adaptada

Para esse caso, de barras quebradas, a Liberty Technologies apud Brito (2002), indica a tabela 4.1 como meio de avaliação de condição de um motor elétrico. Esta tabela mostra que quanto maior a diferença de amplitude entre a frequência de linha e a maior das bandas laterais (no caso toma a frequência $f_{l}-2 f_{s}$ ), melhor a condição do motor. 
Tabela 4.1 - Severidade e recomendações para análise de corrente

\begin{tabular}{|c|c|c|}
\hline $\begin{array}{c}A[d B] \\
F_{1}-2 \times f_{s} \\
\end{array}$ & Avaliação da condição & Ação recomendada \\
\hline$>50 \mathrm{~dB}$ & Excelente & Nenhuma \\
\hline 44 a $50 \mathrm{~dB}$ & Boa & Nenhuma \\
\hline 39 a $44 \mathrm{~dB}$ & Moderada & $\begin{array}{l}\text { Continuar inspeção e analisar } \\
\text { somente a tendência }\end{array}$ \\
\hline 35 a $39 \mathrm{~dB}$ & $\begin{array}{l}\text { Desenvolvendo trinca na barra do } \\
\text { rotor ou juntas com alta resistência }\end{array}$ & $\begin{array}{l}\text { Reduzir intervalo de inspeção e } \\
\text { observar curva de tendência }\end{array}$ \\
\hline 30 a $35 d B$ & $\begin{array}{l}\text { Provavelmente duas barras } \\
\text { trincadas ou quebradas ou juntas de } \\
\text { altas resistências }\end{array}$ & $\begin{array}{l}\text { Fazer análise espectral de vibrações } \\
\text { para confirmar a fonte do problema }\end{array}$ \\
\hline 25 a $30 \mathrm{~dB}$ & $\begin{array}{l}\text { Muitas barras trincadas e/ou } \\
\text { quebradas, várias trincas nos anéis } \\
\text { de curto e falhas severas em toda } \\
\text { gaiola }\end{array}$ & Desmontar o rotor para inspeção \\
\hline$<25 \mathrm{~dB}$ & Severa & $\begin{array}{l}\text { Desmontar ou substituir o rotor para } \\
\text { inspeção }\end{array}$ \\
\hline
\end{tabular}

Fonte: LIBERTY TECHNOLOGIES, INC apud BRITO, 2002

\subsubsection{Análise de Assinatura Elétrica ou ESA (Electrical Signature Analysis)}

Por meio dos mesmos princípios da técnica MCSA, porém mais abrangente e com possibilidade de aplicação em outras máquinas elétricas, tais como geradores e transformadores, o método ESA utiliza além do espectro de frequência em corrente, também o espectro de tensão. Juntos, permitem avaliar a qualidade da energia. Basicamente os sinais de corrente são utilizados para análise de defeitos e falhas elétricas e mecânicas no motor e na carga acionada, enquanto o sinal de tensão é empregado para avaliação, igualmente de problemas elétricos e mecânicos, porém no lado do suprimento de energia. Como exemplo, ao realizar essa técnica a partir de um painel de controle de motores, o sinal de tensão é utilizado para checar problemas no lado de alimentação (transformador de força), enquanto o sinal de corrente serve para diagnosticar defeitos e falhas no lado do motor e da carga (PENROSE, 2004). 
Dentre os defeitos e falhas que o método é capaz de detectar, pode-se destacar (ALL-TEST PRO, 2005):

- Defeitos e falhas de rotores.

- Excentricidade estática e dinâmica de rotores.

- Desbalanceamento de corrente e tensão.

- Qualidade da energia/Presença de frequências harmônicas.

- Desbalanceamento e desalinhamento mecânico.

- Defeitos em rolamentos.

- Danos severos no isolamento.

- Bobinas abertas.

\subsubsection{Análise de Óleo Isolante de Transformadores de Potência}

Apesar da presença cada vez maior de transformadores a seco nas instalações internas prediais, os transformadores a óleo isolante ainda são em grande número, devido principalmente às edificações existentes e instalações ao tempo.

O óleo isolante possui pelo menos três funções num transformador. A primeira delas é proporcionar isolamento elétrico em torno dos diversos componentes energizados que existem em seu interior. A segunda é relacionada à dissipação de calor. O óleo age como um trocador de calor, retirando calor das bobinas e transferindo para 0 ambiente exterior através dos radiadores do transformador. A última função diz respeito a sua capacidade de fornecer informações sobre o estado de deterioração do próprio óleo, bem como do transformador como um todo. Contaminantes e gases presentes, resultado do envelhecimento do líquido isolante, da degradação dos componentes que estão imersos no líquido isolante, tais como, revestimentos isolantes dos condutores, e defeitos/falhas elétricas, arcos elétricos, curtos-circuitos internos, podem ser detectados e avaliados, proporcionando importantes dados sobre a situação interna da máquina elétrica (US-DOI, 2000).

A análise de óleo isolante pode compreender três tipos de testes:

- Análise físico-química. 
- Análise de Gases Dissolvidos ou DGA (Dissolved Gas Analysis).

- Teor de Compostos Furânicos.

\subsubsection{Análise físico-química de óleo isolante}

São testes mais simples que fornecem uma amostra, em curto período de tempo, da situação do óleo. É composta pelos seguintes testes (ACS, 2011):

a) Tensão Interfacial (TIF): A tensão interfacial mede a força necessária para se romper a interface entre dois líquidos não miscíveis, neste caso óleo e água. O teste é sensível à presença de compostos de oxidação, derivados da degradação do óleo isolante, com características polares, como ácidos e outros, e contaminantes polares derivados de materiais construtivos, ou da degradação dos materiais isolantes sólidos. Mede a concentração de substâncias polares no óleo que são responsáveis pela formação da borra. A diminuição da TIF indica a deterioração do óleo.

b) Rigidez dielétrica: A rigidez dielétrica é a medida da capacidade dos óleos isolantes para suportar tensões elétricas sem apresentar ruptura dielétrica. $O$ teste envolve a aplicação de uma tensão alternada a uma taxa controlada a dois eletrodos imersos no óleo isolante, separados por uma distância padrão. Quando da aplicação da tensão, em um determinado momento ocorre a ruptura do dielétrico, neste instante é registrado a tensão de ruptura dielétrica do líquido isolante. Contaminantes, como água, sedimentos e partículas condutoras reduzem a rigidez dielétrica do óleo isolante. A combinação destes contaminantes tendem a reduzir a rigidez dielétrica em um grau maior do que os mesmos contaminantes isoladamente.

c) Fator de potência: É a medida das perdas dielétricas em um líquido isolante elétrico, quando este é submetido a um campo elétrico em corrente alternada. Quanto mais baixo o fator de potência, maior a qualidade do óleo. $O$ aumento do fator de potência está ligado à presença de substâncias que causam condutividade. $O$ fator de potência aumenta 
com a temperatura e com a quantidade de substâncias polares provenientes da deterioração do óleo.

d) Número ou Índice de Neutralização (NN): Os óleos isolantes podem conter constituintes ácidos na forma de aditivos, ou em maior grau, na forma de produtos de degradação. A concentração destes ácidos aumenta rapidamente dependendo do sistema de conservação do óleo. Quando existem altas concentrações de oxigênio dissolvido no óleo e temperaturas de operação elevadas, a velocidade de formação destes ácidos aumenta significativamente. $O$ valor de acidez do óleo indica a vida remanescente deste óleo antes que ele contribua para a degradação de outras partes do transformador, principalmente a isolação celulósica.

e) Cor: É geralmente aceita como um índice do grau de refinamento. Para óleos em serviço, um aumento na escala de cor ASTM ou simplesmente uma mudança, é um indício de contaminação, deterioração, ou ambos.

f) Teor de água: Água no óleo isolante, mesmo que em pequenas quantidades, é muito prejudicial, pois é atraída para as zonas de maior estresse elétrico. A água acelera a degradação tanto da isolação celulósica quanto do próprio óleo isolante, liberando mais água neste processo de deterioração. A "rigidez dielétrica" do sistema isolante é uma função direta do conteúdo de água. Num equilíbrio dinâmico, a água migra tanto da isolação sólida para o óleo isolante quanto o inverso, em função das mudanças de temperatura de operação.

\subsubsection{Análise de gases dissolvidos de óleo isolante ou DGA (Dissolved Gas Analysis)}

Realizada a análise físico-química, a execução de DGA representa um grau mais alto de precisão em análise de óleo isolante e dos motivos de sua degradação. Durante a vida do transformador vários agentes contribuem para a deterioração de seus componentes, líquido isolante, materiais de isolação, ações e reações químicas, sobretemperatura, descargas parciais, arcos elétricos, etc. Todas essas situações produzem gases que ficam dissolvidos no líquido isolante. A quantidade e 
os tipos de gases encontrados são bons indicadores da severidade e tipo de defeito que está ocorrendo, o que propicia condições de avaliar as condições de funcionamento do transformador e planejar ações de mitigação de defeitos e falhas, se for o caso (US-DOI, 2000).

Nesse tipo de técnica, numa amostra de óleo isolante são verificadas a presença e a quantidade de nove gases-chave, de maior importância para fins avaliação, ou seja:

- Hidrogênio $\left(\mathrm{H}_{2}\right)$.

- Oxigênio $\left(\mathrm{O}_{2}\right)$.

- Nitrogênio $\left(\mathrm{N}_{2}\right)$.

- Monóxido de carbono (CO).

- Dióxido de carbono $\left(\mathrm{CO}_{2}\right)$.

- Metano $\left(\mathrm{CH}_{4}\right)$.

- Etileno $\left(\mathrm{C}_{2} \mathrm{H}_{4}\right)$.

- Etano $\left(\mathrm{C}_{2} \mathrm{H}_{6}\right)$.

- Acetileno $\left(\mathrm{C}_{2} \mathrm{H}_{2}\right)$.

A presença dos chamados gases atmosféricos, $\mathrm{O}_{2}, \mathrm{~N}_{2}$ e $\mathrm{CO}_{2}$ é esperada, uma vez que o interior do transformador não é isolado do contato com o ar externo. Valores acima daqueles considerados normais indicam algum defeito em componente interno. $\mathrm{CO}_{2}$ e $\mathrm{O}_{2}$ podem ser consequencia da degradação da celulose de isolação dos condutores (US-DOI, 2000).

A existência combinada dos gases-chave pode indicar diversos defeitos internos no transformador, tais como os mostrados na tabela 4.2. 
Tabela 4.2 - Gases detectados e possíveis causas de sua emissão

\begin{tabular}{l|l}
\hline \multicolumn{1}{c|}{ Gases } & \multicolumn{1}{c}{ Possíveis causas } \\
\hline $\mathrm{H}_{2}, \mathrm{CH}_{4}, \mathrm{C}_{2} \mathrm{H}_{6}, \mathrm{CO}$ & $\begin{array}{l}\text { Isolação deteriorada devido } \\
\text { envelhecimento e estresse elétrico. } \\
\text { Descargas de baixa intensidade, } \\
\mathrm{H}_{2}, \mathrm{CH}_{4}, \mathrm{CO}, \mathrm{C}_{2} \mathrm{H}_{6}\end{array}$ \\
$\mathrm{H}_{2}, \mathrm{CH}_{4}, \mathrm{C}_{2} \mathrm{H}_{6}, \mathrm{C}_{2} \mathrm{H}_{4}, \mathrm{C}_{2} \mathrm{H}_{2}$ (muito), CO & $\begin{array}{l}\text { Descargas estáticas. } \\
\text { elétricos). } \\
\text { Falha térmica abaixo de } 300^{\circ} \mathrm{C} \text {, perto do } \\
\text { papel isolante. }\end{array}$ \\
$\mathrm{H}_{2}, \mathrm{CO}$ & $\begin{array}{l}\text { Falha térmica entre } 300^{\circ} \mathrm{C} \text { e } 700^{\circ} \mathrm{C} \text { perto } \\
\text { do papel isolante. } \\
\mathrm{H}_{2}, \mathrm{CO}, \mathrm{CH}_{4}, \mathrm{C}_{2} \mathrm{H}_{6}, \mathrm{C}_{2} \mathrm{H}_{4}\end{array}$ \\
Todos os gases e Acetileno em \\
grande quantidade
\end{tabular}

Fonte: US-DOI, 2000, adaptada

Os gases produzidos e respectivas quantidades dependem das temperaturas que ocorrem no interior do transformador. Em condições normais de envelhecimento, pequenas quantidades de $\mathrm{H}_{2}, \mathrm{CH}_{4}$ e $\mathrm{CO}$ são produzidas. A decomposição da isolação em celulose se inicia em torno de $100{ }^{\circ} \mathrm{C}$ ou menos e produz $\mathrm{CO}, \mathrm{CO}_{2}, \mathrm{H}_{2}, \mathrm{CH}_{4}$ e $\mathrm{O}_{2}$.

A figura 4.18, sem escala, mostra que hidrogênio $\left(\mathrm{H}_{2}\right)$ e metano $\left(\mathrm{CH}_{4}\right)$ começam a se formar a partir de $150{ }^{\circ} \mathrm{C}$. Note-se que a quantidade de metano $\left(\mathrm{CH}_{4}\right)$, etano $\left(\mathrm{C}_{2} \mathrm{H}_{6}\right)$ e etileno $\left(\mathrm{C}_{2} \mathrm{H}_{4}\right)$ tem crescimento limitado à medida que a temperatura do óleo isolante sobe. A partir de $300{ }^{\circ} \mathrm{C}$, aproximadamente, a presença de metano e etano começa a decrescer. $O$ etileno que surge e cresce a partir de $350{ }^{\circ} \mathrm{C}$, diminui à medida que a temperatura ultrapassa $700^{\circ} \mathrm{C}$ (US-DOI, 2000). 


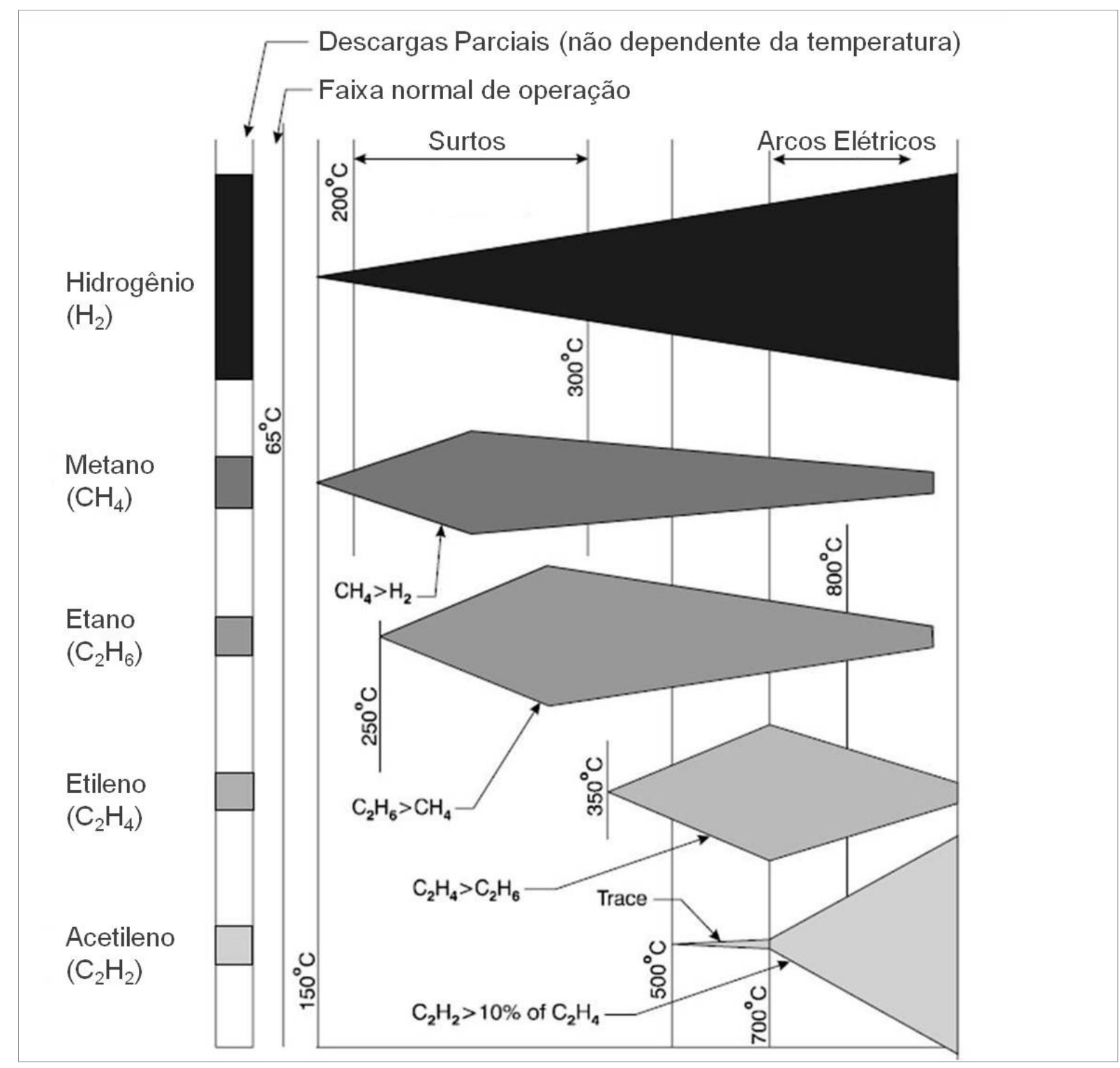

Figura 4.18 - Gases dissolvidos em relação à temperatura do óleo isolante Fonte: US-DOI, 2000, adaptada

Enquanto o hidrogênio $\left(\mathrm{H}_{2}\right)$ cresce em grande quantidade a partir de $150{ }^{\circ} \mathrm{C}$, o acetileno $\left(\mathrm{C}_{2} \mathrm{H}_{2}\right)$ somente surge próximo de $500{ }^{\circ} \mathrm{C}$ e aumenta muito a partir de $700{ }^{\circ} \mathrm{C}$. A figura 4.18 nos mostra ainda que o surgimento desses gases e em quantidades expressivas são fortes indicadores de estresses internos no transformador, que podem ter consequências severas e exigem rápida tomada de providências no sentido de evitar paradas não planejadas e perda de ativo. Uma medida de precaução bastante indicada é manter o funcionamento desse tipo de equipamento em temperaturas nunca superiores a $90{ }^{\circ} \mathrm{C}$ (US-DOI, 2000). 


\subsubsection{Teor de Compostos Furânicos (2-furfural)}

Com o envelhecimento do papel isolante do transformador, são produzidos compostos solúveis em óleo denominados compostos furânicos. Quando o papel isolante envelhece, seu grau de polimerização e sua resistência mecânica diminuem. Altas concentrações de 2-furfural, o composto de maior predominância, no óleo é uma indicação clara da degradação da celulose. Utilizando a técnica de cromatografia líquida de alto desempenho, esta análise fornece subsídios para avaliação do estado de envelhecimento da isolação celulósica dos transformadores, permitindo tomada de decisões quanto à substituição da unidade ou estudos de confiabilidade e sobrecarga de sistemas de potência (ACS, 2011).

\subsubsection{Relação de Transformação de Transformadores ou TTR (Transformer Turn Ratio)}

É a relação entre o número de espiras do lado primário e o lado secundário de um transformador de qualquer tipo e capacidade. Técnica muito precisa, permite identificar pequenas alterações nos enrolamentos devido a curtos-circuitos entre espiras relacionadas a perda de isolamento, estresses elétricos e mecânicos.

Muito simples de ser realizada, permite uma rápida identificação de defeitos e serve como medida de comprovação quando a execução de testes mais elaborados, como por exemplo, o de gases dissolvidos, indicam alguma anomalia.

\subsubsection{Ensaios Não Destrutivos (END)}

As técnicas de END - Ensaios Não Destrutivos são ferramentas poderosas na avaliação das propriedades e da qualidade de componentes de máquinas ou instalações de alto valor cuja falha produz grandes perdas de produção ou afetam a segurança. Embora a maioria dos testes para gestão de manutenção baseada em condição, sejam não destrutivos, costuma-se destacar os ensaios END dos demais, 
uma vez que normalmente emprega em sua execução pessoal com alto grau de especialização e comprovadamente certificados, além de serem recomendados somente para equipamentos que exigem alto grau de segurança e confiabilidade, inclusive ao meio ambiente, cujas consequências de uma falha sejam de grandes consequências, tanto em termos de vidas humanas, quanto em termos econômicos. Alguns casos de END exigem a paralisação do funcionamento do equipamento ou sistema. Sob o ponto de vista da manutenção baseada em condições, o uso de END representa um estágio bastante avançado em gestão de ativos.

Os ensaios não destrutivos compreendem as técnicas de (NASA, 2008):

- Radiografia.

- Partículas Magnéticas.

- Líquido Penetrante.

- Teste Hidrostático.

- Teste Eddy Current.

- Emissão Acústica (já mencionado em 4.2.2).

\section{a) Radiografia:}

É uma das mais poderosas técnicas para identificação de defeitos ou descontinuidades em camadas bastante profundas dos materiais. Produz excelente avaliação de soldagens, vazios e descontinuidades em materiais, levando a resultados de alta confiabilidade e segurança. Baseia-se na absorção diferenciada da radiação penetrante pela peça que está sendo inspecionada. Devido às diferenças na densidade e variações na espessura do material, ou mesmo diferenças nas características de absorção causadas por variações na composição do material, diferentes regiões de uma peça absorverão quantidades diferentes da radiação penetrante. Essa absorção diferenciada da radiação poderá ser detectada através de um filme, ou através de um tubo de imagem ou mesmo medida por detetores eletrônicos de radiação (ANDREUCCI, 2010).

Oferece risco para a saúde de pessoas, o que obriga o isolamento das áreas onde a técnica é aplicada. Não é muito empregada em sistemas prediais, visto que num edifício praticamente não existem equipamentos que ofereçam grande risco à segurança, o que admite a utilização de outras técnicas com adequada confiabilidade. 


\section{b) Partículas magnéticas:}

Utilizada na localização de defeitos e descontinuidades superficiais e subsuperficiais em materiais ferromagnéticos, especialmente em pontos de solda ou sujeitos à fadiga. $O$ ensaio consiste em submeter a peça sob análise a um campo magnético. Nas áreas ou pontos com descontinuidade (ou de falta de continuidade) da região magnetizada surgirá um campo de fuga do fluxo magnético. Com a aplicação das partículas ferromagnéticas, ocorre a aglomeração destas nos campos de fuga, uma vez que serão por eles atraídas devido ao surgimento de pólos magnéticos, levando à visualização do formato e da extensão da descontinuidade (ANDREUCCI, 2009). Também um método de baixa utilização em sistemas prediais, pode ser visto nas figuras 4.19 e 4.20 que seguem. Na figura 4.19 se nota uma descontinuidade entre dois furos que indica uma falha de material. Já na figura 4.20 temos a indicação de uma solda mal executada, inclusive sendo visível o aspecto de baixa qualidade da mesma.

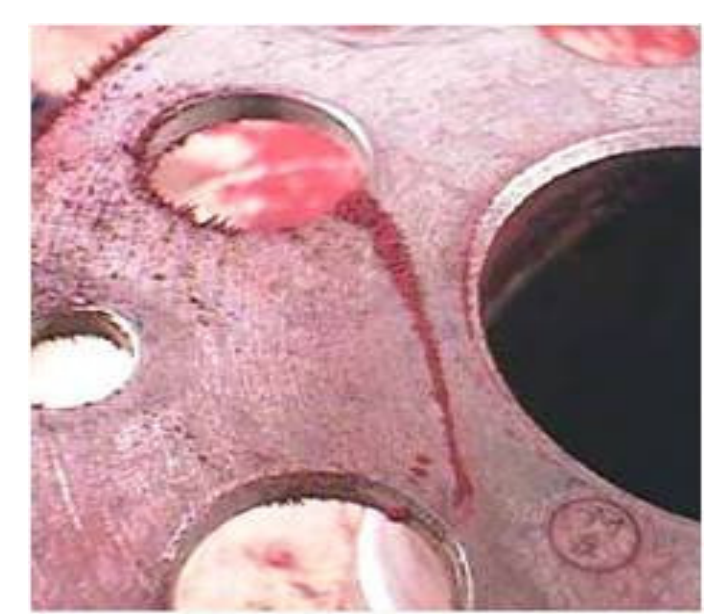

Figura 4.19 - Trinca entre dois furos detectada com partículas magnéticas Fonte: ANDREUCCI, 2009

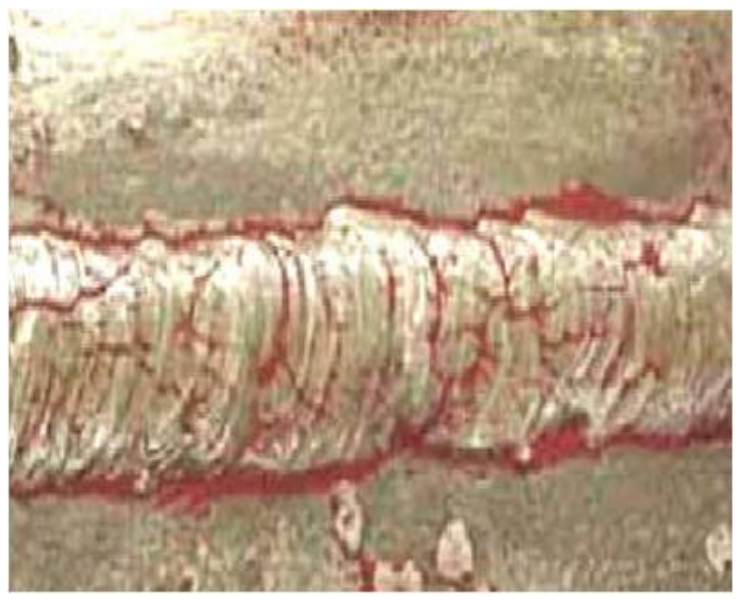

Figura 4.20 - Indicações de trincas sobre solda com partículas magnéticas Fonte: ANDREUCCI, 2009

\section{c) Líquido penetrante:}

Empregado para identificar descontinuidades superficiais em materiais não porosos ou com acabamento grosseiro, inclusive ligas não ferrosas. Utilizado também para verificação de trabalhos de solda. É muito usado em materiais não magnéticos como alumínio, magnésio, aços inoxidáveis, ligas de titânio, e zircônio, além dos materiais magnéticos, vidros, plásticos e cerâmicos vitrificados. Aplica-se 
um líquido, que por capilaridade penetra na trinca. Um outro líquido, o revelador, mostra a imagem da descontinuidade.

Tanto esta técnica com a de partículas magnéticas são suficientes para assegurar a qualidade e confiabilidade requeridas para as soldagens em equipamentos mecânicos prediais.

\section{d) Teste hidrostático:}

Empregado para confirmar a estanqueidade de um equipamento ou tubulação em acordo com seus limites de pressão operacionais. O componente é preenchido com água ou um gás, selado e submetido a uma pressão 1,5 vezes maior que a pressão de operação. Vazamentos e quedas de pressão são anormalidades que devem ser solucionadas.

\section{e) Teste Eddy Current:}

Muito empregado na inspeção de tubos do condensador e evaporador de uma máquina chiller, utiliza o princípio da indução eletromagnética para detecção de defeitos, medição de espessura e falta de homogeneidade superficial. Um sensor, figura 4.21.(a), conectado a um aparelho de medição é introduzido em cada um dos tubos que compõem os trocadores de calor, como mostrado na figura 4.21.(b).

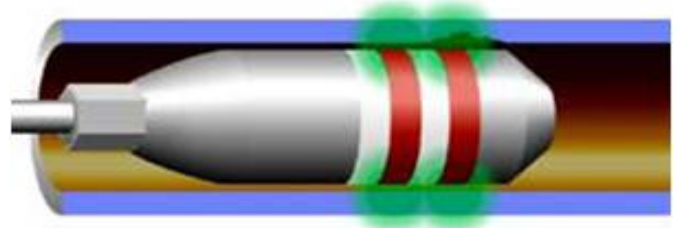

Figura 4.21 (a) - Ponta de prova típica de um teste Eddy Current no interior de tubo (corte) Fonte: ENVIROCOUSTICS, 2011, adaptada

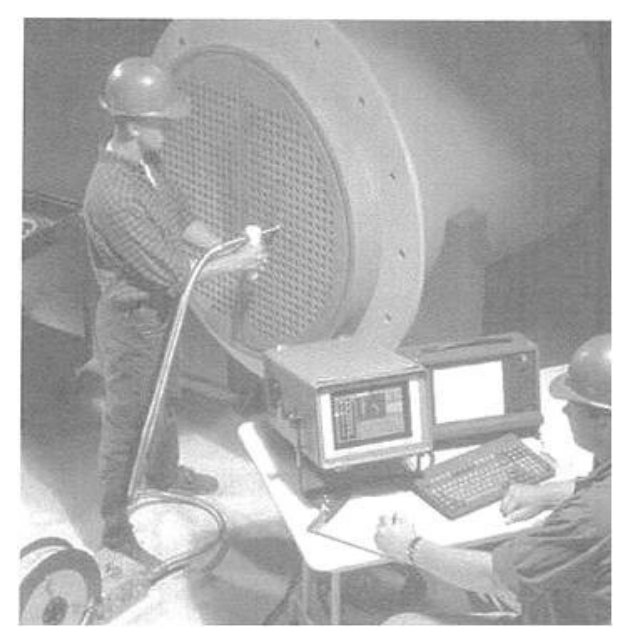

Figura 4.21 (b) - Inspeção dos tubos de um trocador de calor por Eddy Current Fonte: HELLIER, 2001

As descontinuidades afetam a condutividade elétrica do material ou a permeabilidade magnética, que por sua vez indicam a gravidade do defeito. 
A execução desse teste durante toda a vida da máquina chiller é essencial para garantir suas condições operacionais, além de ser uma medida de precaução com relação a sua integridade, pois essa inspeção permite identificar situações que podem a danos irreversíveis no equipamento.

\subsubsection{Equipamentos e técnicas preditivas aplicáveis - resumo}

$\mathrm{Na}$ tabela $4.2 \mathrm{se}$ faz um resumo de todas as técnicas preditivas apresentadas. Como visto, esses métodos de teste abrangem todos os equipamentos que compõem um sistema de água gelada do tipo expansão indireta com condensação a água, exceto sua instrumentação e equipamentos de supervisão e controle, softwares e etc.

Por meio dessa tabela se pode notar que um mesmo equipamento pode ser inspecionado por mais de uma técnica, o que proporciona a oportunidade de escolher aquela mais eficiente num determinado momento ou então a que oferece uma visão mais rápida da situação. Essa é a situação, por exemplo, de inspeção de redutores de rotação, que pode começar pela aplicação de ultrasom. Caso algum defeito seja percebido, aplica-se a medição de vibrações.

Outro é o caso dos testes que se complementam, como o caso de compressores de ar. Enquanto a análise de vibração oferece a informação de como estão o motor e seus componentes, a aplicação de ultrasom fornece dados sobre a existência ou não de vazamentos. O mesmo exemplo serve para disjuntores em média tensão. A análise por ultrasom é muito boa para detectar descargas parciais, a termografia para encontrar pontos aquecidos que servem para comprovar as citadas descargas.

$E$, ainda podem ocorrer aplicações de uma técnica para um equipamento para a qual não foi prevista. Esse exemplo é o de uso de análise de vibrações para detectar anomalias mecânicas no interior de um transformador a óleo. Embora não tenha sido desenvolvida para isso, é possível utilizar a mesma conhecendo-se as restrições de aplicação. 
Tabela 4.3 - Equipamentos e técnicas preditivas aplicáveis

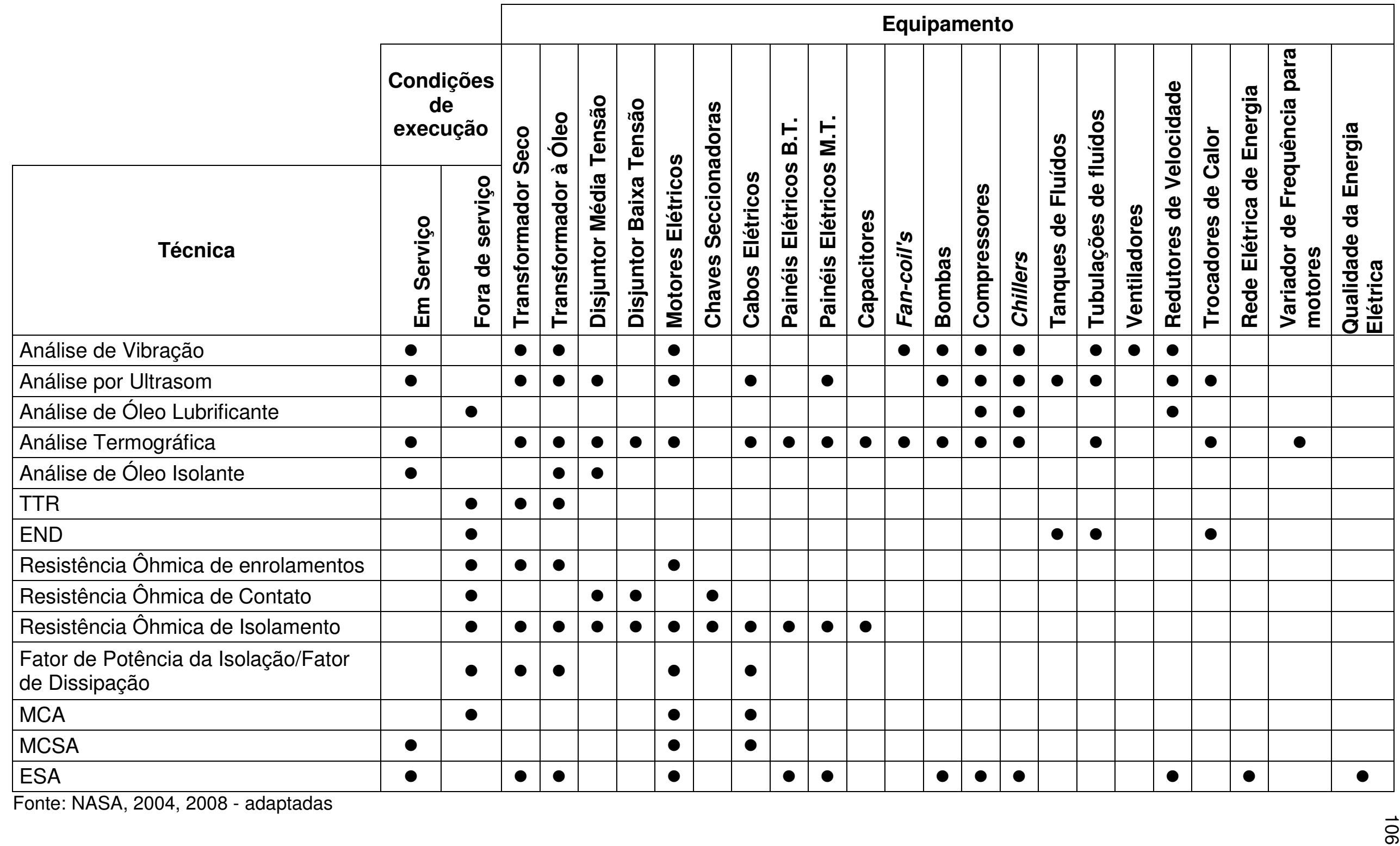


Cada técnica é mais ou menos eficiente em acordo com uma dada situação. A escolha da mais apropriada ou das que se complementam, qual aplicar em primeiro lugar, etc, pode ser uma estratégia de controle de qualidade, de confiabilidade, disponibilidade e custos de manutenção muito eficaz. 


\section{CONSIDERAÇÕES FINAIS}

Nesta dissertação se buscou relacionar temas ligados à sustentabilidade do ambiente construído, em especial àquele relacionado aos edifícios de escritórios e sua manutenção, escolhendo como exemplo de aplicação um sistema de ar condicionado de expansão indireta com condensação a água. A seleção de um sistema desse tipo teve como principal motivo sua relevância para o conforto térmico, satisfação e saúde das pessoas em seu ambiente de trabalho, tanto quanto seu desempenho e confiabilidade para a estratégia de sustentabilidade da edificação.

Os conhecimentos sobre conforto térmico no ambiente de trabalho evoluíram bastante a partir dos trabalhos de Fanger nas décadas de 1960 e 1970. A influência sobre as pessoas ficou conhecida e os sistemas de ar condicionado desde então passam por uma contínua evolução tecnológica de modo a atender os novos requisitos de conforto. $\mathrm{O}$ avanço e aprimoramento da eletrônica e programas de supervisão e controle, bem como o advento de redes informatizadas de comunicação de dados proporcionam a operação de sistemas de ar condicionado com alta precisão. O conhecimento sobre materiais, o uso de programas de cálculo, bem como o acúmulo de experiências de campo, tornaram os equipamentos mais eficientes. Resultado dessa cadeia de processos de desenvolvimento, o desempenho desse tipo sistema teve notável crescimento.

Embora todo esse avanço venha ocorrendo, na literatura técnica muito se encontra sobre projetos e novas instalações, mas pouco sobre manutenção desses sistemas. Um rápido olhar sobre os programas de instituições de educação percebe seu pequeno foco nas atividades de manutenção predial, incluindo sistemas de ar condicionado, atualmente um dos principais tópicos de sustentabilidade de um edifício, objeto dos principais programas de certificação predial. Nesse cenário, a gestão de manutenção predial não produziu avanços significativos. Na maioria das edificações ainda se pratica quase que só manutenção corretiva e alguma manutenção preventiva periódica. Manutenção baseada em condição e centrada em confiabilidade são praticamente inexistentes no setor de edifícios comerciais.

Mesmo os mais recentes e usuais processos de certificação de edifícios praticamente nada mencionam diretamente a respeito de estratégias e melhores 
práticas de manutenção. Partem do pressuposto que, para atingir determinados parâmetros de desempenho, deve existir um programa de manutenção estruturado para os ativos. Os agentes de comissionamento acabam incluindo programas e memoriais de manutenção de sistemas prediais quando da execução de trabalhos de certificação predial como forma de criar procedimentos para manter a continuidade dos desempenhos atingidos. Assim, mesmo não havendo nada explícito sobre estratégias de manutenção, essa prática é um reconhecimento dos benefícios que a mesmas podem alcançar.

A partir da compreensão do desenvolvimento sustentável e o que esse conceito pode trazer de benefícios para a sociedade, a manutenção de edifícios e seus sistemas prediais ganha um novo papel. De um mal necessário, passa a ser percebida como um meio essencial de gerenciamento do ciclo de vida dos ativos. Nesse contexto, a gestão de manutenção feita de modo eficiente e eficaz contribui para extensão da vida útil e maior durabilidade dos produtos, e de todos os benefícios daí advindos, tais como: menor depleção dos recursos naturais, menores emissões para o ar, solo e água, conservação da energia embutida dos materiais, etc. Além disso, a manutenção das funções dos ativos e dos desempenhos requeridos proporciona um ambiente interno de qualidade, que maximiza a saúde, satisfação e produtividade dos ocupantes do edifício. No entanto, provavelmente o principal quesito que deve ser considerado é a evolução para uma economia de baixo carbono, que a cada ano exigirá melhor desempenho dos sistemas prediais, principalmente do sistema de ar condicionado, o que demanda maior qualidade da gestão de manutenção.

Dentre as estratégias de manutenção a que mais se integra aos conceitos de desenvolvimento sustentável é a de manutenção preventiva baseada em condição. Sua filosofia que toma como base o monitoramento dos parâmetros de funcionamento de máquinas e análise de tendência de falha possui como grandes vantagens: (i) redução acentuada das falhas de ativos, uma vez que consegue identificar com bastante precisão o que deve ser reparado; (ii) melhora a qualidade do reparo, devido à menor probabilidade de erro humano; (iii) reduz os custos de manutenção, menor quantidade de falhas levam à menor exigência por peças e materiais novos; (iv) redução de estoques de peças sobressalentes; (v) melhora a programação de paradas para reparos, é possível escolher o melhor momento para realização do conserto; (vi) diminui as paradas de funcionamento devido falhas não 
previstas; (vii) redução de falhas catastróficas que levam à perda do ativo ou causam necessidade de reparos de altos custos; (viii) aumento da vida útil dos ativos, visto que eles quebram menos, duram mais; (ix) maior disponibilidade dos ativos, eles quebram menos, portanto estão maior tempo à disposição para funcionar; ( $\mathrm{x}$ ) maior confiabilidade dos ativos, o que aumenta a confiança dos operadores nos componentes, equipamentos e sistemas; (xi) menor aplicação de mão de obra, diminuição de horas extras, visto que as ações corretivas imprevistas diminuem muito; (xii) menores custos com insumos diversos, tais como água, energia, produtos químicos, e; (xiii) menor geração de resíduos e descarte de ativos, materiais e peças. Como se percebe e já mencionado, a gestão de manutenção baseada em condição possui um forte efeito cascata, onde cada melhoria alcançada provoca imediatamente outra, o que acaba levando a uma situação de benefício geral, que leva a um ambiente de bastante eficiência e satisfação com os serviços prestados.

Outro aspecto importante e que destaca a manutenção preventiva baseada em condição, é seu grande conceito tecnológico, isto é, essa estratégia se baseia exclusivamente em técnicas preditivas que utilizam equipamentos e programas de computação altamente desenvolvidos e com capacidade de análise cada vez melhores, o que leva à medição de parâmetros de máquinas com alto grau de precisão, o que se relaciona perfeitamente com os sistemas mais sofisticados existentes nos edifícios de alto padrão. Com 0 avanço das técnicas de monitoramento e das redes de transmissão de dados, o monitoramento em tempo real dos parâmetros de máquinas será mais acessível, o que colocará a MP-BC num outro patamar de desenvolvimento.

Apesar da não abordagem nessa dissertação, visto que não fez parte de seu escopo, sistemas de ar condicionado, como por exemplo, de volume variável de refrigerante, sistemas de expansão direta e condensação a ar e etc, bem como outros sistemas prediais e seus acessórios, também podem ser abrangidos pela MP-BC com resultados bastante satisfatórios.

Finalizando essas considerações, cabe mencionar que a manutenção dos edifícios e seus sistemas prediais é fundamental para a sustentabilidade das edificações durante toda sua vida útil. Num mundo com economia de baixo carbono, onde a minimização dos recursos extraídos da natureza, a redução das emissões e do consumo de energia são objetivos necessários, a extensão da vida útil, a maior 
durabilidade dos ativos são essenciais. Nesse cenário, a manutenção preventiva baseada em condição, além de incorporar alto grau de desenvolvimento tecnológico, característica das sociedades contemporâneas, consiste numa excelente estruturação metodológica das atividades de manutenção, para contribuir, no que Ihe diz respeito, para a realização deste objetivo pela humanidade. 


\section{REFERÊNCIAS}

ACS LABORATÓRIOS. Goiânia. Análise de óleo isolante. Disponível em: < http://www.hplc.com.br/servicos/analise-de-oleo-isolante.html>. Acesso em: 11 abr. 2011.

ADWEL INTERNACIONAL LTD. Winding resistance testing. Canadá, 1978, 10p. (WRT-100). Disponível em: <http://www.irispower.com/PDF/WRT-100_english.PDF>. Acesso em: 09 abr. 2011.

AFEFY, I.H. Reliability-Centered Maintenance methodology and application: A case study. Engineering, n. 2, p. 863-873, 2010.

ALL-TEST PRO. Electrical motor diagnostics for generators. Disponível em: $<$ http://www.reliabilityweb.com/art06/generator_diagnostics.htm>. Acesso em: 27 mar. 2011.

ANDREUCCI, R. Ensaio por Partículas Magnéticas. ABENDE - Associação Brasileira de Ensaios Não Destrutivos e Inspeção e ANDREUCCI, Assessoria e Serviços Técnicos Ltda, 2009, 67 p.

ANDREUCCI, R. Radiologia industrial. ABENDE - Associação Brasileira de Ensaios Não Destrutivos e Inspeção e ANDREUCCI, Assessoria e Serviços Técnicos Ltda, 2010, 119 p.

ATP_FLUKE. Testando a resistência de isolação. ATP - American Technical Publishers, Inc - Fluke Corporation, 2005, 60p.

BACKLUND, F. Managing the introduction of reliability-centred maintenance, RCM - RCM as a method of working within hydropower organizations. 2003. 317p. Tese (Doutorado) - Lulea University of Technology, Suécia, 2003.

BACKLUND, F.; AKERSTEN, P.A. RCM introduction: process and requirements management aspects. Journal of Quality in maintenance Engineering, v. 9, n. 3, p. 250-264, 2003.

BANSAL, P. Evolving sustainably: A longitudinal study of corporate sustainable development. Strategic Management Journal, v. 26, ed.3, p. 197-218, 2005. 
BENGTSSON, M. Condition based maintenance systems - an investigation of technical constituents and organizational aspects. 2004. 118p. Tese (Licenciatura) n. 36 - Mälardalen University, Suécia, 2004.

BERTLING, L. On evaluation of RCM for maintenance management of electric power systems. Power Engineering Society Meeting, IEEE, v.3, p. 2638-2640, 2005.

BONALDI, E.L.; OLIVEIRA, L.E.L.; PIERINI, T.B.; CONCEIÇÃO, C.A.; LOPES, L.; CALISTO, T.N.; MARQUES, A.B. Análise e identificação de falhas em motores de indução em indústrias petroquímicas através da técnica de análise da assinatura elétrica - ESA. Induscon - VIII Conferência Internacional de Aplicações Industriais, Poços de Caldas, 2008. 7p.

BRITO, J.N. Desenvolvimento de um sistema inteligente híbrido para diagnóstico de falhas em motores de indução trifásicos. Tese (Doutorado) UNICAMP - Universidade Estadual de Campinas, Campinas, 238 p., 2002.

CERVI, J.L.; CARVALHO, P.G.M. A pegada ecológica: breve panorama do estado das artes do indicador de sustentabilidade no Brasil. In: VII Encontro Nacional da Ecoeco - Fortaleza (CE), 2007. Fortaleza. Publicações, 2007. 13p. Disponível em: <http://www.ecoeco.org.br/conteudo/publicacoes/encontros/vii_en/mesa3/trabalhos/a _pegada_ecologica_breve_panorama.pdf>. Acesso em: 20 set. 2010.

CHE-ANI, A.I.; CHOHAN, A.H.; N.A. GOH; M.M.TAHIR; M. SURAT; I.M.S. USMAN. Sustainable design formulation in achieving best practice of building maintenance. World Academy of Science, Engineering and Technology, n. 53, 2009, 5 p.

CHIMACK, M.; AARDSMA, J.; NOVOSEL, D. Final report NCEMBT 061102 Energy reduction through practical scheduled maintenance -. National Center for Energy Management and Building Technologies, 202p., 2006.

CNSC (Canadian Nuclear Safety Commission). Maintenance Programs for Nuclear Power Plants - Regulatory Standard S-210. 24p, 2007.

COHEN, B; BRUYN, M.; FAROLE, T. Mainstreaming Sustainable Consumption and Production and Resource Efficiency into Development Planning. UNEP (United Nations Environment Programme), 48p, 2009. 
COLE, R.J.; KERNAN, P.C. Life-Cycle Energy Use in Office Buildings. Building and Environment - Elsevier Science Ltd., v. 31, n. 4, p. 307-317, 1996.

CONNER, R. Overview of oil analysis in PdM Technologies. Corporate Programs Manager. Disponível em: <http://www.pdmprofessionals.com/articles-oillubrication/90-overview-oil-analysis-pdm-technologies.html>. Acesso em: 26 fev. 2011.

CROWTHER, P. Design for disassembly to recover embodied energy. Australia, 1999. PLEA - 16th International Conference on Passive and Low Energy Architecture - Melbourne-Brisbane-Cairns, Australia, 1999.

CSA. CSA S478-95 - Guideline on durability in buildings. Canadian Standards Association, 112 p., 2007.

DESHPANDE, V.S.; MODAK, J.P. Application of RCM to a medium scale industry. Reliability Engineering \& System Safety, Elsevier Science Ltd., n. 77, p. 31-43, 2002.

EC\&M. Testing your insulation can save your Motors. Electrical Construction \& Maintenance Magazine, 2 p., 2002. Disponível em:

<http://login.ecmweb.com/wall.aspx?ERIGHTS_TARGET=http\%3A\%2F\%2Fecmweb .com\%2Fmag\%2Felectric_testing_insulation_save\%2F>. Acesso em 20 mar. 2011.

ENVIROCOUSTICS. Automated UT Tubes Inspection. Envirocoustic Non Destructive Testing. Disponível em: <http://www.envirocoustics.gr/ >. Acesso em: 08 mar. 2011.

ENVIROCOUSTICS. EC-RFT Rapid Tube Inspection. Envirocoustic Non Destructive Testing. Disponível em: <http://www.envirocoustics.gr/ >. Acesso em: 08 mar 2011.

ETI, M.C.; OGAJI, S.O.T.; PROBERT, S.D. Reducing the cost of preventive maintenance (PM) through adopting a proactive reliability-focused culture. Applied Energy - Elsevier/ScienceDirect, n. 83, p. 1235-1248, 2006.

FAY, R., TRELOAR, G.; IYER-RANIGA, U. Life-cycle energy analysis of buildings: a case study. Building Research \& Information, 28(1), p.31-41, 2000. 
FIESP (Federação das Indústrias do Estado de São Paulo). ConstruBusiness 2008 - 7올 Seminário da Indústria Brasileira da Construção - Planos Nacionais para a Construção do Crescimento. 83 p., 2008.

FILHO, G.B. Dicionário de termos de manutenção e confiabilidade. Edição Mercosul. Rio de Janeiro: Editora Ciência Moderna Ltda, 2000. 285 p.

FISK, W.J. Health and productivity gains from better indoor environments and their implications for the U.S. Department of Energy .Lawrence Berkeley National Laboratory - E-Vision 2000 Conference, 31p, 2000.

FISK, W.J. Review of health and productivity gains from better IEQ. Lawrence Berkeley National Laboratory - Proceedings of Healthy Buildings, v.4, p. 23-34, 2000.

FLUKE CORPORATION. Insulation resistance testing. 8p., 2007. Disponível em: http://support.fluke.com/find-sales/Download/Asset/1579160_6115_ENG_C_W.PDF. Acesso em: 16 fev. 2011.

GONÇALVES, O.M.; GRAÇA, M.E.A. Desempenho de sistemas sanitários prediais: conceitos fundamentais. Revista de Engenharia Mackenzie, São Paulo, v. 70, n. 177, p. $7-13,1986$

GREGOREC, J. The Basics of Insulation Testing. NETA WORLD, 6p., 2006.

HELLIER, C.J. Handbook of nondestructive evaluation. McGraw-Hill, New York, NY, USA, 1a Edição, 603 p., 2001.

HELMAN, H.; ANDERY, P.R.P. Análise de falhas (Aplicação dos métodos de FMEA - FTA). TQC - Gestão da qualidade total - Série Ferramentas da Qualidade, Fundação Christiano Ottoni, Escola de Engenharia da UFMG, Belo Horizonte, MG, v. 11, 156 p., 1995.

HILL, R.C.; BOWEN, P.A. Sustainable construction: principles and a framework for attainment. Constrution management and economics, v. 15, ed.3, p. 223-239, 1997. 
HOFF, J.L. Sustainable buildings: Addressing long-term building envelope durability. RCl 24th International Convention and Trade Show. 15p., 2009. Disponível em:

$<$ http://www.roofingcenter.org/syncshow/uploaded_media/Addressing\%20LongTerm\%20Durability(1).pdf>. Acesso em: 10 jan. 2011.

HOPWOOD, B; MELLOR, M.; O'BRIEN, G. Sustainable development: Mapping different approaches. Sustainable Development - I3, p.38-52, 2005.

HOUGHTON, J.T.; FILHO, L.G.M.; GRIGGS, D.J.; MASKELL, K. Stabilization of Atmospheric Greenhouse Gases: Physical, Biological and Socio-Economic Implications. IPCC (Intergovernmental Panel on Climate Change), Technical Paper III, 61 p., 1997.

IAEA (International Atomic Energy Agency). Implementation strategies and tools for condition based maintenance at nuclear power plants - IAEA - TECDOC 1551. 178p., 2007.

IAEA (International Atomic Energy Agency). Application of reliability centred maintenance to optimize operation and maintenance in nuclear power plants IAEA-TECDOC-1590. 140p., 2007.

IAEA (International Atomic Energy Agency). Guidance for optimizing nuclear power plant maintenance programmes - IAEA-TECDOC-1383. 140p., 2003.

IDRUS, A.; KHAMADI, M.F.; LATEEF, O.A. Value-based maintenance management model for university buildings in Malaysia: A critical review Journal of Sustainable Development, v. 2, n. 3, p. 127-130, 2009.

INO. Manual INO de manutenção de motores elétricos de corrente contínua. Disponível em: <http://www.ino.com.br/downloads/ino_manual_completo.pdf.>. Acesso em: 09 abr. 2011.

JARREL, D.; SISK, D.; BOND, L. Prognostics and condition based maintenance (CBM) - A scientific crystal ball. PNNL-SA-36771 (Pacific Northwest National Laboratory). Disponível em: < http://www.pnl.gov/dsom/publications/36771.pdf>. Acesso em: 20 abr. 2011. 
JOHN, V.M.; SATO, N.M.N.; AGOPYAN, V.; SJOSTROM, C. Durabilidade e Sustentabilidade: Desafios para a construção civil brasileira. 10p. Disponível em: < http://durar.pcc.usp.br/artigos/Durabilidade\%20e\%20Sustentabilidade.pdf.>. Acesso em; 22 mai. 2011.

JUNNILA, S.; HORVARTH, A.; ASCE, A.M. Life-Cycle environmental effects of an office building. Journal of Infraestructure Systems, p. 157-166, dezembro 2003.

KATES, R.W.; PARRIS, T.M.; LEISEROWITZ, A.A. What is sustainable development? - Goals, Indicators, Values, and Practice. Environment: Science and Policy for Sustainable Development, v. 47, n. 3, 13p., 2005.

LAMIN, P.C.M.F. Acompanhamento preditivo de motores de indução trifásicos através da análise de fluxo magnético. Dissertação (Mestrado) - UNICAMP Universidade Estadual de Campinas, Campinas, 127 p., 2003.

LANDRY, M.; MERCIER, A.; OUELLET, G.; RAJOTTE, C.; CARON, J.; ROY, M.; $\mathrm{BRIKCl}, \mathrm{F}$. A new measurement method of the dynamic contact resistance of HV circuit breakers. IEEE PES Transmission and Distribution Conference and Exposition Latin America, 8 p., 2006.

LANGSTON, C.; WONG, F. K. W.; HUI, E. C. M.; SHEN, L. Strategic assessment of building adaptive reuse opportunities in Hong Kong. Building and Environment, n. 43, p. 1709-1718, 2008.

LANHAM, C. Understanding the tests that are recommended for electric motor predictive maintenance. Baker Instrument Company, 5p. Disponível em: < http://www.skf.com/files/692662.pdf >. Acesso em 15 fev. 2011.

LUTZKENDORF, T.; LORENZ, D. Sustainable property investment: valuing sustainable buildings through property performance assessment. Building Research \& Information, 33 (3), p. 213, 2005.

MARÇAL, R.F.M. Um método para detectar falhas incipientes em máquinas rotativas baseado em análise de vibrações e lógica fuzzy. 124p., 2000. Tese (Doutorado) - Universidade Federal do Rio Grande do SUL, Rio Grande do Sul, 2000.

MÁRQUEZ, A.C.; LEÓN, P.M.; FERNÁNDEZ, G.; MÁRQUEZ, C.P.; CAMPOS, M.L. A practical view to maintenance management. Journal of Quality in Maintenance Engineering - v. 15, n. 2, p. 167-178, 2009. 
MECHEFSKE, C.K. Machine Condition Monitoring and Fault Diagnostics. In: SILVA, C.W. Vibration and shock handbook. CRC Press - Taylor \& Francis Group, USA, $2005.1872 \mathrm{p}$.

MELO, L.C.B.; AMORIM,S.R.L. O subsetor de edificações da construção civil no Brasil: uma análise comparativa em relação à União Européia e aos Estados Unidos. Produção, v. 19, n. 2, 11 p., 2009.

MENSAH, F.K. Condition Assessment of Electrical Contacts of Disconnectors. 2011. 130 p. Dissertação (Mestrado) - Delft University of Technology, 2011.

MOUBRAY, J. RCM II - Reliability-centered maintenance. Industrial Press Inc, New York, USA, 1997, 440 p.

NASA (National Aeronautics and Space Administration). Reliability centered building and equipment acceptance guide. 314 p., 2004.

NASA (National Aeronautics and Space Administration). Reliability centered maintenance guide for facilities and collateral equipment. 472 p., 2008.

NICÁSIO, J.A.P. Técnicas de inspeção em tanques de armazenamento. 4ํㅜㅇ Seminário Nacional de Sistema Industriais e Automação. 8p., 2009.

PENROSE, H. W. Eletronic motor diagnostics. InfraMation 2004 Proceedings, 8 p., 2004. Disponível em:

<http://www.flirt250.com/PDF/Flir\%20T250\%20Thermal\%20Camera\%20PdM\%20Electric\%20Motor\%20Diagnostics\%202004.pdf>. Acesso em: 16 fev.2011.

PILLAY, P; XU, Z. Motor current signature analysis. Clarkson University, NY, IEEE, 8 p., 1996. Disponível em: <http://people.clarkson.edu/ pillayp/c61.pdf>. Acesso em: 04 abr. 2011.

RAUSAND, M. Reliability centered maintenance. Reliability Engineering and System Safety - Elsevier Science Limited, v. 60, p. 121-132, 1998.

RESENDE, M.M.; BARROS, M.S.B.; MEDEIROS, J.S. A influência da manutenção na durabilidade dos revestimentos de fachada de edifícios. $11 \mathrm{p}$. Disponível em: < http://mauricioresende.pcc.usp.br/Workdurabilidade\%20\%20Maur\%C3\%ADcio.pdf>. Acesso em: 22 mai. 2011. 
SAPP, D. Facilities Operations \& Maintenance. WBDG (Whole Building Design Guide). Disponível em: <http://www.wbdg.org/om/om.php >. Acesso em 28 nov. 2010.

SCHNEIDER, J; GAUL, A.J.; NEUMANN, C.; HOGRAFER, J.; WELLBOW, W.; SCHWAN, M.; SCHNETTLER. Asset management techniques. Electrical Power \& Energy Systems - 28, p. 643 - 654, 2006.

SCHULTMANN, F.; SUNKE, N. Energy-oriented deconstruction and recovery planning. Building Research \& Information, v. 35, n. 6, p. 602-615, 2007.

SEV, A. How Can the Construction Industry Contribute to Sustainable

Development? A Conceptual Framework. Sustainable Development. v.17, ed.3, 13 p., 2009.

SILVA, D.A. Diagnóstico de equipamentos de propulsão naval através de análise de vibração. Dissertação (Mestrado) - Universidade Federal do Rio de Janeiro, Rio de Janeiro, 145 p., 2006.

SMITH, D.P. Predictive Maintenance (PdM) Centralization for Significant Energy Savings. Predictive Service, LLC, 15 p. Disponível em:

<http://www.worldenergy.org/documents/congresspapers/479.pdf>. Acesso em: 22 abr. 2011.

SOLOMON, S.; QIN, D.; MANNING, M.; CHEN, Z.; MARQUIS, M.; AVERYT, K.; TIGNOR, M.M.B.; MILLER, H.L. IPCC 2007: Climate Change 2007: The Physical Science Basis. Contribution of Working Group I to the Fourth Assessment Report of the Intergovernmental Panel on Climate Change. Cambridge University Press, Cambridge, United Kingdom and New York, NY, USA, 2007, 996 p.

SOUBBOTINA, T.P. Beyond Economic Growth - An Introduction to Sustainable Development. The International Bank for Reconstruction and Development/The World Bank. 2004. Disponível em: < http://www.worldbank.org/depweb/english/beyond/global/beg-en.html>. Acesso em: 24 set. 2010.

SOUZA, M.S.M. - Métodos analíticos para lubrificantes e isolantes. Disponível em: <http://www.quimicaederivados.com/revista/qd382/oleos.htm>. Acesso em 26 fev. 2011. 
STEVENS, D. Equipment condition monitoring. Disponível em: <http://www.vibanalysis.co.uk/> Acesso em: 06 mar. 2011.

STRANGE, T; BAYLEY, A. Sustainable Development - Linking economy, society, environment. OECD Insights, p. 23, 2008. Disponível em:

$<$ http://wdn.ipublishcentral.net/oecd/viewinsidehtml/3108875690194\#>. Acesso em: 29 ago. 2010.

SULLIVAN, G.P.; PUGH, R.; MELENDEZ, A.P.; HUNT, W.D. Operations \& Maintenance - Best Practices - A guide to achieving operational efficiency Release 3.0. FEMP - Federal Energy Management Program - US-DOE, 321 p., 2010.

UNEP (United Nations Environment Programme). Building and Climate Changes Status, Challenges and Opportunities. 87 p., 2007. Disponível em:

<http://www.unglobalcompact.org/docs/issues_doc/Environment/climate/Buildings_a nd_climate_change.pdf>. Acesso em: 24 set. 2010.

US-DOI (United States Department of the Interior). FIST 3-30 - Facilities Instructions, Standards, and techniques - Transformer maintenance. Bureau of Reclamation, Denver, Colorado. Hidroeletric Research and Technical Services Group D-850, 87 p., 2000.

US-DOI (United States Department of the Interior). Testing solid insulation of electrical equipment. Facilities Instructions, Standards and Techniques., v. 3-1, 69 p., 1991.

US-EPA-EFFECTS (United States Environmental Protection Agency). Effects. Disponível em: <http://www.epa.gov/climatechange/fq/effects.html>. Acesso em: 02 mai. 2010.

US-EPA-GHG (United States Environmental Protection Agency). Greenhouse Gas Emissions. Disponível em: $<$ http://www.epa.gov/climatechange/emissions/index.html>. Acesso em: 02 mai. 2010.

US-EPA-SCIENCE (United States Environmental Protection Agency). Science. Disponível em: <http://www.epa.gov/climatechange/fq/science.html>. Acesso em: 02 mai. 2010. 
VANIER, D.J. Asset management 101: A primer. APWA International Public Works Congress - NRCC/CPWA Seminar series "Innovations in urban infrastructure", nrcc44300, 15p, 2000.

WBDG - WHOLE BUILDING DESIGN GUIDE. Productive. Disponível em: < http://www.wbdg.org/design/productive.php $>$. Acesso em 15 mar. 2011. WCED (Word Commission on Environment and Development). Our Common Future - Chapter 2: Towards Sustainable Development. Disponível em: <http://www.un-documents.net/ocf-02.htm\#!>. Acesso em: 29 ago. 2010.

WHITE, J. Critical Maintenance for Circuit Breakers. NETA WORLD, 8 p., 2007.

WILLIAMS, D.; SUTRISNA, M. An evaluation of the role of facilities managers in managing sustainability and remedial actions in reducing $\mathrm{CO}_{2}$ emissions in the built environment. COBRA 2010 - RICS - The Construction, Building and Real Estate Research Conference of the Royal Institution of Chartered Surveyors Dauphine Université, 22p., 2010.

WOOD, B. Towards innovative building maintenance. Structural Survey. v. 23, n. 4, p. 291-297, 2005.

WORSHAM, W.C. Is preventive maintenance necessary? Maintenance World. Disponível em:< www.maintenanceworld.com/Articles/worshamw/ispreventive.html>. Acesso em: 29 abr. 2011. 